\title{
Ontwikkelingen op de arbeidsmarkt voor hoger opgeleiden: gevolgen voor het HBO
}

Citation for published version (APA):

Allen, J. P. (2013). Ontwikkelingen op de arbeidsmarkt voor hoger opgeleiden: gevolgen voor het HBO. ROA. ROA Reports No. 012 https://doi.org/10.26481/umarep.2013012

Document status and date:

Published: 01/01/2013

DOI:

10.26481/umarep.2013012

Document Version:

Publisher's PDF, also known as Version of record

\section{Please check the document version of this publication:}

- A submitted manuscript is the version of the article upon submission and before peer-review. There can be important differences between the submitted version and the official published version of record.

People interested in the research are advised to contact the author for the final version of the publication, or visit the DOI to the publisher's website.

- The final author version and the galley proof are versions of the publication after peer review.

- The final published version features the final layout of the paper including the volume, issue and page numbers.

Link to publication

\footnotetext{
General rights rights.

- You may freely distribute the URL identifying the publication in the public portal. please follow below link for the End User Agreement:

www.umlib.nl/taverne-license

Take down policy

If you believe that this document breaches copyright please contact us at:

repository@maastrichtuniversity.nl

providing details and we will investigate your claim.
}

Copyright and moral rights for the publications made accessible in the public portal are retained by the authors and/or other copyright owners and it is a condition of accessing publications that users recognise and abide by the legal requirements associated with these

- Users may download and print one copy of any publication from the public portal for the purpose of private study or research.

- You may not further distribute the material or use it for any profit-making activity or commercial gain

If the publication is distributed under the terms of Article $25 \mathrm{fa}$ of the Dutch Copyright Act, indicated by the "Taverne" license above, 
Ontwikkelingen op de arbeidsmarkt voor hoger opgeleiden: gevolgen voor het HBO

Jim Allen

ROA-R-2013/12 


\section{Colofon}

(C) Researchcentrum voor Onderwijs en Arbeidsmarkt (ROA). Niets uit deze uitgave mag op enige manier worden verveelvoudigd zonder voorafgaande schriftelijke toestemming van de directeur van het ROA.

\section{Researchcentrum voor Onderwijs en Arbeidsmarkt}

School of Business and Economics

Maastricht University

\section{Vormgeving}

ROA secretariaat, Maastricht

\section{Verkoop}

Researchcentrum voor Onderwijs en Arbeidsmarkt email: secretary-roa-sbe@maastrichtuniversity.nl website: www.roa.nl

ISBN: 978-90-532I-523-4

december 2013 


\section{Inhoud}

Executive Summary $\quad$ v

1 Inleiding 1

2 De kennissamenleving: het blijvend belang van professionele expertise 5

3 De ICT-revolutie: de noodzaak van innovatie en kennismanagement 17

4 Globalisering: toenemende behoefte aan internationale oriëntatie op de werkplek

5 De veranderende economische structuur: het belang van ondernemerschapscompetenties

6 High-performance organisaties: mobilisatie van het beschikbare menselijk kapitaal

7 Toenemende onzekerheid: de noodzaak om flexibel te zijn

$\begin{array}{llr}8 & \text { Conclusies } & 57\end{array}$

9 Wat kunnen we hieruit leren? $\quad 61$

$\begin{array}{ll}\text { Literatuur } & 67\end{array}$ 



\section{Executive Summary}

Zes trends ....

In dit rapport onderzoeken we de gevolgen van een zestal trends die door Humburg en van der Velden (2013) in een recent overzichtsartikel worden aangewezen als in sterke mate bepalend voor de plaats die hoger opgeleiden vervullen in de economie en samenleving. Deze trends zijn: de kennissamenleving, de ICT-revolutie, globalisering, verandering van de economische structuur, high-performance organisaties, en toenemende onzekerheid. In dit rapport spitsen we die trends toe op de arbeidsmarktpositie van afgestudeerden van het $\mathrm{HBO}$. We maken daarbij gebruik van gegevens van de $\mathrm{HBO}-$ Monitor, de jaarlijkse enquête onder afgestudeerden van het $\mathrm{HBO}$. Daarnaast is gebruik gemaakt van gegevens van het internationale onderzoek onder afgestudeerden REFLEX (Allen en Van der Velden, 20II).

\section{... met bijbehorende competentiedomeinen}

Deze trends hebben in eerste instantie gevolgen voor de type competenties waarover afgestudeerden dienen te beschikken. Alle genoemde trends hebben waarschijnlijk enig effect op de mate waarin vrijwel elke denkbare competentie nodig kan zijn in het werk van afgestudeerden. Met een dergelijke alles-hangt-met-alles-samen redenering schieten we echter weinig op. Om deze reden verbinden Humburg en Van der Velden op pragmatische gronden elke trend met een bepaald competentiedomein waar volgens hen de betreffende trend het meest direct effect op heeft.

Voor de kennissamenleving is dit het competentiedomein van de professionele expertise. Voor de ICT-revolutie gaat het om innovatie en kennismanagement. Het meest direct effect van de globalisering betreft het toenemend belang van internationale oriëntatie, terwijl de verandering van de economische structuur het belang van ondernemerschapscompetenties onderstreept. High-performance organisaties stellen vooral hoge eisen aan werknemers in termen van competenties op het gebied van het mobiliseren van menselijke hulpbronnen. Tenslotte dienen afgestudeerden vanwege de toegenomen onzekerheid een hogere mate van flexibiliteit te kunnen vertonen. 


\section{Expert worden vergt tijd}

Een belangrijke bevinding van dit rapport is dat het tijd vergt om expert te worden. De overgrote meerderheid van afgestudeerden vindt dat er aanzienlijk meer tijd nodig is om expert te worden dan de één à twee jaren die zijn verstreken sinds de respondenten van de $\mathrm{HBO}-$ Monitor hun opleiding hebben verlaten. Dit impliceert dat op het moment dat de HBO-Monitor enquête wordt afgenomen, de meeste afgestudeerden qua competentieontwikkeling bij lange na niet klaar zijn, maar nog volop bezig.

\section{Expertise is meer dan vakkennis}

Expert worden behelst overigens meer dan alleen vakkennis, maar ook het vermogen om als expert te denken en te beschikken over brede academische vaardigheden. Verder dienen Nederlandse professionals in staat te zijn om adequaat om te gaan met de wet- en regelgeving waarmee ze in toenemende mate worden geconfronteerd. Met name dit laatste blijkt steeds belangrijker te worden, hoewel in absolute zin het nog altijd minder belangrijker lijkt te zijn dan vakkennis en vooral academische vaardigheden.

\section{Een zeker tekort aan vakkennis is niet zonder meer een probleem}

Wanneer we kijken naar de mate waarin het $\mathrm{HBO}$ met de eisen omtrent professionele expertise om weet te gaan, zien we dat vooral op het punt van vakkennis de tekorten fors zijn. Een nadere analyse van deze tekorten en ook surplussen leert dat deze vaak in een lagere beloning resulteren. Ook het oordeel van afgestudeerden over de aansluiting tussen de $\mathrm{HBO}$-opleiding en hun werk is beduidend minder positief wanneer het eigen niveau van vakkennis afwijkt van wat op het werk wordt vereist. Voor andere indicatoren van baankwaliteit blijkt echter dat lichte tekorten geen echt probleem vormen, en voor wat betreft de gepercipieerde carrièremogelijkheden zelfs een licht voordeel opleveren. Dit lijkt een bevestiging te geven dat lichte tekorten tot op zekere hoogte een indicatie zijn van een dynamische en uitdagende werkomgeving.

\section{ICT transformeert het werk van afgestudeerden}

Hoewel de ICT-revolutie doorwerkt op vrijwel alle aspecten van competentievereisten, is het effect het meest direct merkbaar op competenties op het gebied van innovatie en kennismanagement. Vanzelfsprekend wordt hierdoor meer een beroep gedaan op ICT-vaardigheden zelf, maar ook op het vermogen om informatie te vergaren en het vermogen om nieuwe ideeën en oplossingen te bedenken.

Uit de in dit rapport gepresenteerde analyses blijkt dat het vereist niveau van ICT-competenties sinds 2005 merkbaar is gestegen voor afgestudeerden werkzaam binnen hun kerndomein. Deze stijging vertaalt zich in een stijging in het percentage 
afgestudeerden met een tekort aan deze competenties. Deze stijging is echter heel licht, en het niveau van de tekorten ligt nog vrij laag, in 201 nog minder dan $20 \%$. Er lijkt op dit punt vooralsnog geen reden voor HBO-instellingen om zware maatregelen te treffen om dit stijgende tekort te lijf te gaan, gezien het feit dat de meeste jongeren tegenwoordig min of meer vanzelf in aanraking komen met ICT, in zowel de privésfeer als op school. Er lijkt eerder een iets andere les te trekken uit het stijgende belang van ICT, namelijk dat bestaande functies door toenemend ICT gebruik worden getransformeerd.

\section{De directe gevolgen van globalisering voor het $\mathrm{HBO}$ zijn niet zo groot ...}

Op het eerste gezicht lijken de directe gevolgen van de globalisering voor het $\mathrm{HBO}$ relatief beperkt. In tegenstelling tot het WO stijgt de instroom van buitenlandse studenten in het HBO heel langzaam. Wel brengen HBO'ers steeds vaker een deel van de studie in het buitenland door. Ondanks deze toename in buitenlandervaring tijdens de studie lijkt er echter geen sprake van te zijn dat meer Nederlandse HBO'ers na afronding van de studie ervoor kiezen om in het buitenland te werken. Dit percentage daalt zelfs de laatste jaren, na een korte opleving in het begin van het vorige decennium. Als relativering van deze cijfers kan worden opgemerkt dat ongeveer een derde van alle HBO'er vijf jaar na afstuderen in een organisatie werkt met een internationale reikwijdte.

\section{... maar buitenlandse talenkennis wordt steeds belangrijker, ook in Nederland}

Hoe zit het met de competenties op het gebied van internationale orientatie? Hierbij kan worden gedacht aan kennis van buitenlandse talen, maar ook de bereidheid om begrip tonen voor andere standpunten, met name van mensen met een andere culturele achtergrond. Het vereiste niveau van deze laatste competentie ligt stabiel erg hoog. Dat van buitenlandse talenkennis ligt veel lager, maar is merkbaar gestegen in de afgelopen zes jaren. Deze stijging vertaalt zich in een lichte stijging in het aandeel afgestudeerden met een tekort aan talenkennis.

Zoals zou worden verwacht hangt het vereist niveau van taalvaardigheden sterk samen met het wel of niet in het buitenland werken. Opvallend is echter dat de algemene stijging in het vereist niveau in het geheel wordt bepaald door mensen in Nederland werken. Dit laat zien dat ook in Nederland het werk steeds internationaler wordt.

\section{Zelfstandig ondernemerschap komt steeds vaker voor}

$\mathrm{Na}$ jarenlang op een laag niveau te hebben gezeten is het percentage afgestudeerden dat voor zichzelf werkt de laatste vijf jaren fors gestegen. Opvallend is dat dit geldt vooral voor mensen die op eigen niveau werkzaam zijn buiten hun eigen richting. Hoewel dit deels wordt bepaald door extreme percentages voor de sector KUO, is de stijging ook bij de meeste andere sectoren ook zichtbaar. De stijging is al ruim vóór 
de crisis in 2008 uitbrak begonnen, en kan daarom niet geheel daaraan toegeschreven worden, al heeft het ongetwijfeld een effect gehad. Omdat zelfstandigen/freelancers overwegend in kleine organisaties werken, is ook het percentage afgestudeerden dat in een kleine organisatie werkt duidelijk toegenomen in de afgelopen Io jaar.

\section{Er is een tekort aan ondernemerschapscompetenties}

Uit het internationale REFLEX-onderzoek blijkt dat slechts $16 \%$ van de HBO'ers hun opleiding een goede voorbereiding vond op het gebied van het ontwikkelen van ondernemerschapsvaardigheden. Desalniettemin blijken ondernemerschapscompetenties doorgaans op hoog niveau te worden vereist. Het makkt het voor het vereist niveau van ondernemerschapscompetenties weinig uit of men buiten de eigen richting werkt, zolang als het nog om een HBO functie gaat. Dit suggereert dat ondernemerschap een sterk generieke kenmerk is. Het hoge vereiste niveau vertaalt zich in een relatief hoog aandeel afgestudeerden dat met een tekort aan deze competenties kampt. Vooral onder mensen die in kleine organisaties werken lijken deze competenties belangrijker te worden in de tijd.

\section{HBO'ers worden anders ingezet in organisaties dan voorheen}

High-performance organisaties vereisen vooral een hoog niveau van competenties op het gebied van het mobiliseren van menselijke hulpbronnen. Dit houdt in dat men de eigen werkzaamheden zelfstandig dient te kunnen uitvoeren, en in staat is om met anderen productief samen te werken, aan hen uit te leggen wat de bedoeling is, en waar nodig aan te sturen en op te komen voor het eigen standpunt.

Wellicht een weerspiegeling van de trend naar nieuwe organisatievormen is de dalende trend in het percentage HBO'ers dat leiding geeft. Wel blijkt het werk van afgestudeerden een sterke mate van onderlinge afhankelijkheid te vertonen met andere werknemers in de organisaties waarin ze werken.

\section{Ook niet-leidinggevenden moeten in staat zijn collega's aan te sturen}

Zoals wellicht zou worden verwacht gezien het relatief laag percentage afgestudeerden dat leiding geeft, ligt het vereist niveau van het vermogen om capaciteiten van anderen aan te spreken het laagst van de mobilisatiecompetenties. Opvallend is echter dat het gemiddeld niveau van deze competentie niet daalt, ondanks de daling in het percentage leidinggevenden. Dit ligt aan het feit dat het vereist niveau van deze competentie alles behalve laag ligt bij mensen die formeel gezien geen leiding geven. Met name voor de communicatieve en leidinggevende vaardigheden ligt het aandeel afgestudeerden met een tekort zorgwekkend hoog. Vooral dat laatste is opvallend, gezien het relatief laag niveau waarop deze competentie wordt vereist. Het lijkt alsof afgestudeerden die deze competentie in hun werk nodig hebben onvoldoende hierop zijn voorbereid. 
Toenemende onzekerheid is in veel opzichten - hoewel niet uitsluitend - de negatieve keerzijde van veel van de andere trends. Dit betekent vooral dat mensen in staat moet zijn om flexibel te reageren op alles wat ze in hun werk of carrière tegenkomen. Er zijn veel manieren waarmee deze flexibiliteit te realiseren kan zijn, maar het is aannemelijk dat vooral kennis van andere vakgebieden en het vermogen om nieuwe dingen te leren de opties van mensen zal vergroten wanneer onverwachte ontwikkelingen zich voordoen.

Uit het REFLEX onderzoek blijkt dat oud-studenten met een tijdelijk contract, of die voor zichzelf werken, veel minder vaak een sterk gevoel van werkzekerheid hebben dan mensen met een vast contract c.q. die in loondienst zijn bij een bedrijf of organisatie. Ook concurrentie, marktinstabiliteit en recente ontslaggolven gaan gepaard met een lager vertrouwen in de zekerheid van de baan. Verder lijkt een lage mate van autonomie samen te hangen met een lager niveau van werkzekerheid.

Wanneer we naar de objectieve situatie kijken blijkt dat baanzekerheid vooral een cyclisch karakter heeft. Dit geldt ook voor het percentage afgestudeerden met een tijdelijk contract. Uit het REFLEX onderzoek is echter gebleken dat verreweg de meest afgestudeerden 5 jaar na afstuderen inmiddels een vaste aanstelling hebben.

Het vereist niveau van kennis van andere vakgebieden en het vermogen om nieuwe dingen te leren verandert nauwelijks in de tijd. Er is wel een groot verschil tussen de twee competenties als het gaat om het absolute niveau waarop ze worden vereist. Leercompetenties worden op een tamelijk hoog niveau vereist, terwijl kennis van andere vakgebieden op een veel lager niveau wordt vereist. Merkwaardig genoeg is het juist de kennis van andere vakgebieden waar de grootste tekorten te zien zijn. Hoewel dit gemiddeld op een relatief laag niveau wordt vereist, komt het blijkbaar relatief vaak voor dat de mensen die deze competentie nodig hebben, er niet over beschikken. In beide gevallen tonen mensen in tijdelijke dienst vaker een tekort dan mensen in vaste dienst. 



\section{Inleiding}

In een recent overzichtsartikel wijzen Humburg en van der Velden (20I3) op zes trends die in sterke mate bepalend zijn voor de plaats die hoger opgeleiden vervullen in de economie en samenleving. Deze trends zijn: de kennissamenleving, de ICT-revolutie, globalisering, verandering van de economische structuur, high-performance organisaties, en toenemende onzekerheid.

In dit rapport gaan we in op deze trends, en op de gevolgen voor de transitie van het HBO naar de arbeidsmarkt. Zoals Humburg en Van der Velden opmerken staan deze trends niet op zichzelf, maar zijn ze nauw met elkaar verweven. In recente jaren lijkt vooral de ICT revolutie de belangrijkste motor voor de andere trends. In een recent essay voor de kenniskamer van het Ministerie van Onderwijs, Cultuur en Wetenschap wordt dit punt door Allen en Van der Velden (20I2) nader uitgewerkt. Zo wordt door het internet het gemak waarmee bedrijven buiten de eigen landsgrenzen kunnen handelen vergroot, en krijgt internationale studenten- en arbeidsmobiliteit een enorme boost door de informatie over studiemogelijkheden en baanvacatures die tegenwoordig vrijwel universeel online beschikbaar is. Moderne technologieën maken het ook veel gemakkelijker voor organisaties om hun werkpraktijken anders in te richten, waarbij enerzijds kleinere organisaties beter in staat zijn om te concurreren met grotere bedrijven, en anderzijds deze grotere bedrijven beter in staat zijn om meer autonomie te verlenen aan professionals op de werkvloer. Een keerzijde van de snelle veranderingen die door ICT-ontwikkelingen worden versterkt is dat dit bedrijven en organisaties dwingt om op zoek te gaan naar soms vergaande vormen van flexibilisering van het werk, waardoor werknemers een deel van hun voormalige zekerheid kwijt kunnen raken.

Dit alles betekent dat het verbinden van elk van deze trends met de ontwikkeling van specifieke competentievereisten altijd enigszins arbitrair is. Goed beschouwd hebben alle genoemde trends waarschijnlijk enig effect op de mate waarin vrijwel elke denkbare competentie nodig kan zijn in het werk van afgestudeerden. Met een dergelijke alles-hangt-met-alles-samen redenering schieten we natuurlijk weinig op. Om deze reden verbinden Humburg en Van der Velden op pragmatische gronden elke trend met een bepaald competentiedomein waar volgens hen de betreffende trend het meest directe effect op heeft. 
Voor de kennissamenleving is dit het competentiedomein van de professionele expertise. Zoals hieronder zal worden beredeneerd, behelst dit meer dan alleen vakkennis, maar ook het vermogen om als expert te denken en het beschikken over brede academische vaardigheden. Verder blijkt dat Nederlandse professionals in vrijwel alle werkdomeinen in toenemende mate geconfronteerd met wet- en regelgeving die hun handelingsvrijheid inperkt. In de HBO-Monitor vragenlijst wordt deze professionele expertise vooral weerspiegeld in de volgende competenties: kennis van het eigen vakgebied, het vermogen deze vakkennis toe te passen, het vermogen om verbanden te leggen, het vermogen of hoofd- van bijzaken te onderscheiden, het vermogen om logisch te redeneren, kritische reflectie, en het vermogen om conform budget, planning of richtlijnen te werken.

Net als de kennissamenleving werkt de ICT-revolutie door op vrijwel alle aspecten van competentievereisten, maar het effect is het meest direct merkbaar op competenties op het gebied van innovatie en kennismanagement. Vanzelfsprekend wordt hierdoor meer een beroep gedaan op ICT-vaardigheden zelf, maar ook op het vermogen om informatie te vergaren en het vermogen om nieuwe ideeën en oplossingen te bedenken.

Globalisering heeft eveneens een rimpelwerking dat vergaande consequenties kan hebben zelfs voor mensen die er niet direct mee te maken krijgen. Het meest voor de hand liggend directe effect is op de internationale oriëntatie van werknemers. Dit zou betekenen dat kennis van buitenlandse talen belangrijker wordt, evenals de bereidheid om begrip te tonen voor andere standpunten, in dit geval van mensen met een andere culturele achtergrond.

De verandering van de economische structuur leidt tot een toenemend belang van ondernemerschapscompetenties. Hierbij kan worden gedacht aan het vermogen om onder druk goed te functioneren, om knopen door te hakken, en de bereidheid de eigen nek uit te steken.

High-performance organisaties vereisen vooral een hoog niveau van competenties op het gebied van het mobiliseren van menselijke hulpbronnen. Dit houdt in dat men de eigen werkzaamheden zelfstandig dient te kunnen uitvoeren, en in staat is om met anderen productief samen te werken, aan hen uit te leggen wat de bedoeling is, en waar nodig aan te sturen en op te komen voor het eigen standpunt.

Toenemende onzekerheid is in veel opzichten - hoewel niet uitsluitend - de negatieve keerzijde van veel van de andere trends. Dit betekent vooral dat mensen in staat moet zijn om flexibel te reageren op alles wat ze in hun werk of carrière tegenkomen. Er zijn veel manieren waarmee deze flexibiliteit te realiseren kan zijn, maar het is aannemelijk dat vooral kennis van andere vakgebieden en het vermogen om nieuwe dingen te leren de opties van mensen zal vergroten wanneer onverwachte ontwikkelingen zich voordoen. 
Het is belangrijk bij het lezen van dit rapport te onthouden dat deze verbinding van competenties met trends vooral pragmatisch is, en dat de competenties die onder een bepaalde trend worden besproken ook onder invloed van de andere trends belangrijker kunnen worden. Dit geldt met name voor de competenties op het gebied van de professionele expertise en van innovatie en kennismanagement, die waarschijnlijk sterke wapens zijn die afgestudeerden helpen omgaan met elk van de genoemde trends. Maar ook andere competenties zijn uiteraard op verschillende manieren inzetbaar. We zullen waar relevant hierop wijzen in de betreffende paragrafen van dit rapport. 



\section{De kennissamenleving: het blijvend belang van professionele expertise}

Zoals Humburg en Van der Velden duidelijk maken, is er niets nieuw aan het concept van de kennissamenleving. Al in de jaren zeventig werd door Bell (1973) de term "post-industriële samenleving" gebruikt om aan te geven hoe belangrijk theoretische kennis is geworden in vergelijking met de meer op massaproductie gerichte wereld van vóór en kort ná de tweede wereldoorlog. Deze transitie is vooral in de hand gewerkt door globalisering en snelle technologische verandering.

De kennissamenleving is misschien niet nieuw, maar door de snelle technologische ontwikkelingen en toegenomen globale samenwerking en concurrentie tussen bedrijven en organisaties is het voortdurend aan verandering onderhevig. Dit heeft gevolgen op vrijwel alle terreinen van de economie en samenleving, maar het meest directe gevolg voor hoger opgeleiden is dat professionele expertise voor hen belangrijker is dan ooit tevoren. Dit behelst veel meer dan alleen vakspecifieke kennis. Humburg en Van der Velden leggen dit als volgt uit. In tegenstelling tot het toepassen van pragmatische en contextuele kennis, is kenniswerk tegenwoordig meer een kwestie van ongestructureerde besluitvorming. Hiervoor is naast vakkennis ook het vermogen om als expert te denken en het beschikken over brede academische vaardigheden onmisbaar. Het kost echter veel tijd en moeite om expert te worden. Het verschil tussen een beginnend professional en expert ligt in het feit dat een expert geacht wordt in staat te zijn om af te wijken van routine oplossingen. Hierin ligt het belang van brede academische vaardigheden zoals analytisch vermogen en reflectie. Verder wordt steeds belangrijker dat experts in staat zijn om adequaat om te kunnen gaan met de toenemende wet- en regelgeving waarbinnen ze dienen te werken.

\section{Expert worden vergt tijd}

Auteurs zoals Hayes (I98I) en Ericsson en Crutcher (1990) merken op dat het veel tijd kost om expert te worden in een bepaald beroep, gewoonlijk tussen de vijf en tien jaren in functie. Dit wordt bevestigd door resultaten uit het REFLEX onderzoek, waarin afgestudeerden van het hoger onderwijs in verschillende landen onder meer werden gevraagd een inschatting te geven van de tijd die nodig is voor een gemiddelde afgestudeerde om expert te worden in het beroep waarin ze op het enquêtemoment (zo'n 5 jaar na afstuderen) werkzaam waren. Figuur 2.I geeft de resultaten weer voor oud-studenten van het Nederlandse HBO die op het moment van enquêtering in hun kerndomein werkzaam waren, dat wil zeggen in functies werkzaam waren waarvoor 
minimaal een $\mathrm{HBO}$-opleidingsniveau in de eigen of een verwante opleidingsrichting vereist was.

\section{Figuur 2.1}

Tijd nodig voor een gemiddelde afgestudeerde om expert te worden in huidige beroep (uitsluitend afgestudeerden werkzaam in kerndomein)

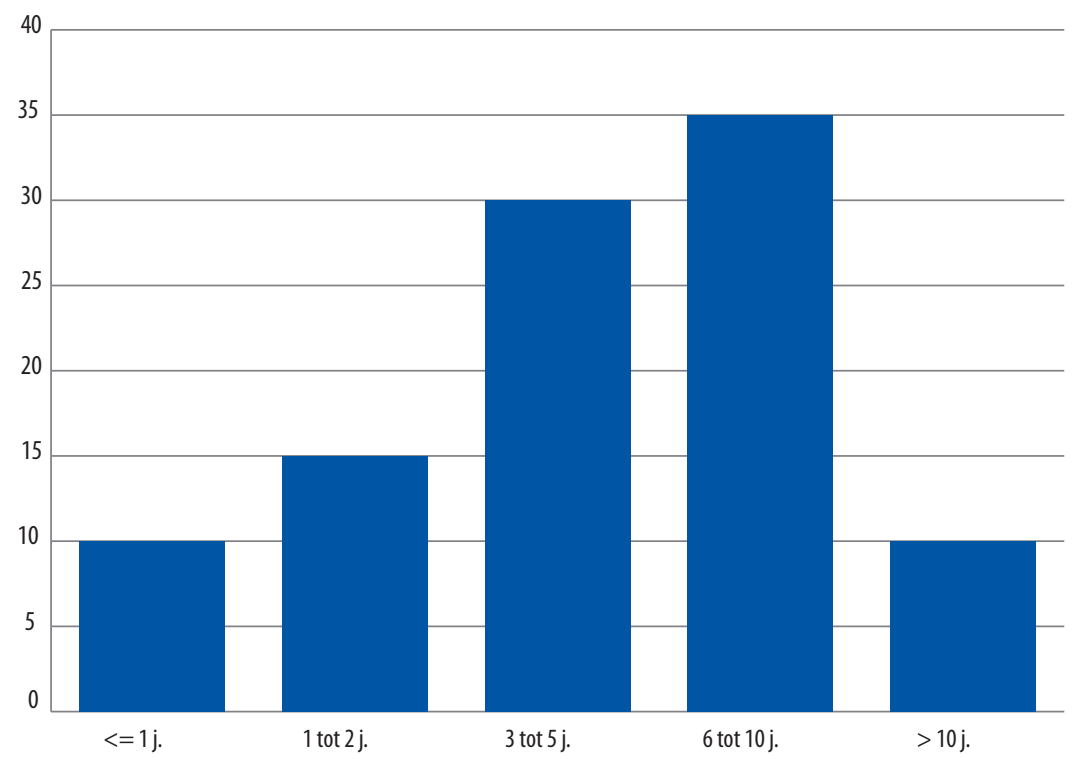

Bron: REFLEX project

Uit figuur 2.I blijkt dat de overgrote meerderheid van afgestudeerden vindt dat er aanzienlijk meer tijd nodig is om expert te worden dan de één à twee jaren die zijn verstreken sinds de respondenten van de HBO-Monitor hun opleiding hebben verlaten. Deze bevinding plaatst de HBO-Monitor meteen in een duidelijk en ook interessant perspectief, namelijk van een onderzoek onder (voornamelijk jonge) mensen die nog bezig zijn met de transitie van de relatief beschermde wereld van de collegebanken naar de status van volwaardige expert in hun eigen vakgebied. Één van de consequenties hiervan is dat recent afgestudeerden qua competentieontwikkeling bij lange na niet klaar zijn, maar nog volop bezig.

Hoewel we niet over de longitudinale gegevens beschikken die nodig zouden zijn om deze stelling te bewijzen, geven de resultaten van het REFLEX onderzoek een sterke indicatie dat dit het geval is. Net als in de HBO-Monitor wordt aan de respondenten van het REFLEX onderzoek een lijst competenties voorgelegd waarop ze zowel hun eigen als het voor hun functie vereiste niveau konden aangeven. ${ }^{I}$ Wanneer het niveau

I. De REFLEX competentielijst verschilt enigszins van die van de HBO-Monitor, maar behelst een vergelijkbare set competenties. Oud-studenten werden gevraagd zowel het eigen als het vereist niveau van deze competenties te scoren op een zevenpuntschaal, variërend van I (zeer laag) naar 7 (zeer hoog). 
van competenties die belangrijk worden geacht voor professionele expertise sterk stijgt gedurende de eerste jaren van de loopbaan, ligt het voor de hand dat deze stijging vooral geldt voor beroepen waarin meer tijd nodig is om expert te worden. Als dit het geval is, zouden we een sterk positieve relatie verwachten tussen deze benodigde tijd en het niveau van competenties die vooral relevant worden geacht voor professionele expertise. In het REFLEX onderzoek wordt een drietal competenties genoemd die dicht bij het begrip van professionele expertise ligt zoals Humburg en van der Velden dat beschrijven. Dit zijn de beheersing van het eigen vakgebied, analytisch denken en kritische reflectie. Uit figuur 2.2 blijkt dat het niveau van deze competenties inderdaad positief samenhangt met de benodigde tijd om expert te worden.

\section{Figuur 2.2}

Vereist niveau geselecteerde competenties, naar tijd nodig voor expert status (uitsluitend afgestudeerden werkzaam in kerndomein)

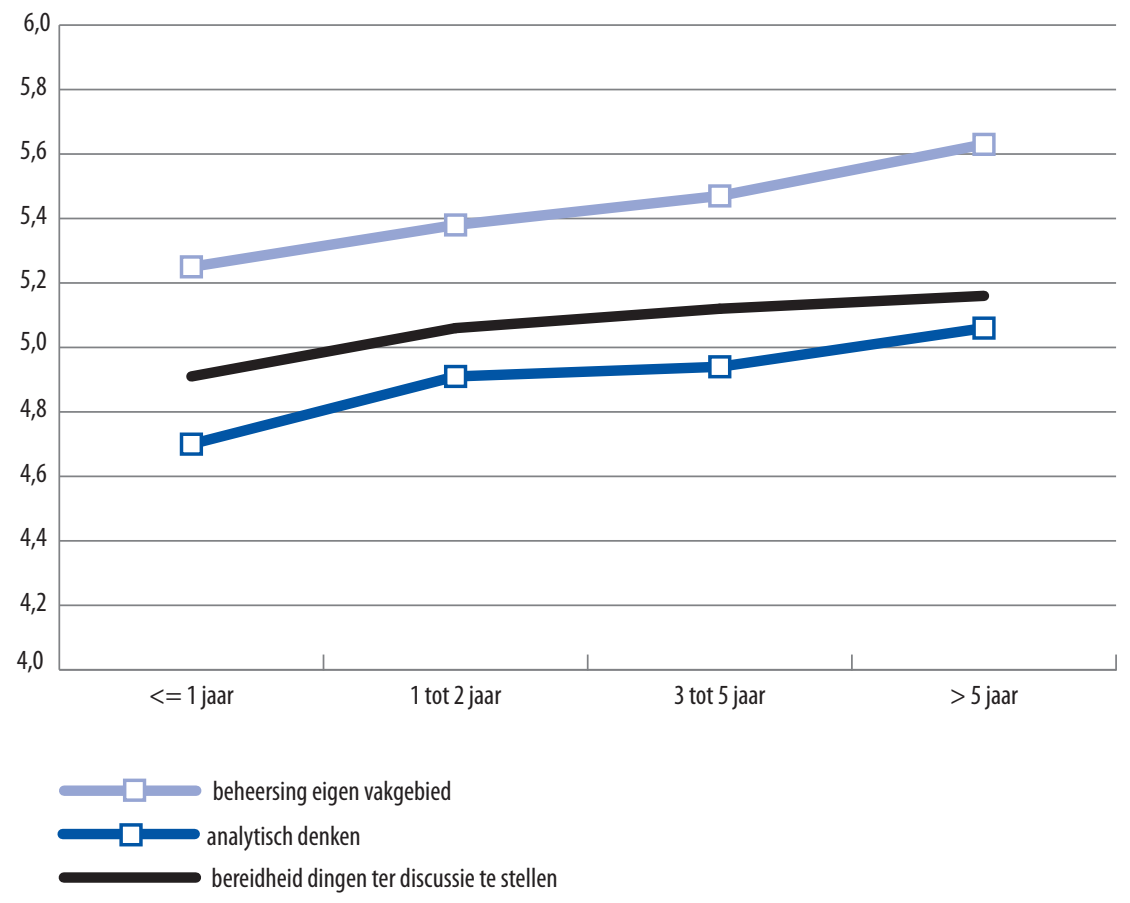

Bron: REFLEX project

Dit zijn echter niet de enige competenties die belangrijker zijn in functies waarbij meer tijd nodig is om expert te worden dan in functies waar deze benodigde tijd veel korter is. Ook communicatieve-, innovatieve- en leervaardigheden tonen een soortgelijk beeld, evenals het vermogen om gezag uit te oefenen. Dit onderstreept de veelzijdigheid van professionele expertise. Het is echter niet zo dat experts zich van anderen onderscheiden doordat ze beter in alles dienen te zijn. Andere competenties 
hebben namelijk hooguit een zwakke relatie met tijd nodig om expert te worden. In het geval van talenkennis, kennis van andere vakgebieden, ICT vaardigheden, alert zijn op nieuwe mogelijkheden en samenwerking is zelfs geen enkele relatie te zien.

\section{Expertise blijft belangrijk}

We hebben dus sterke indicaties dat bepaalde competenties belangrijker worden binnen individuele loopbanen, als men zich van beginner tot expert ontwikkelt. Worden dergelijke competenties ook belangrijker in de tijd voor elkaar opvolgende cohorten HBO-afgestudeerden? Figuur 2.3 toont voor elkaar opvolgende cohorten afgestudeerden van de $\mathrm{HBO}-$ Monitor die werkzaam zijn binnen hun kerndomein de ontwikkeling van een zestal competenties die inhoudelijk sterk verwant zijn aan het begrip professionele expertise. Deze competenties zijn: kennis van eigen vakgebied, het vermogen om vakkennis in de praktijk toe te passen, het vermogen om verbanden te leggen, het vermogen om hoofd-van bijzaken te onderscheiden, het vermogen om logisch te redeneren, de bereidheid om ideeën ter discussie te stellen (die wij in het vervolg kritische reflectie noemen), en het vermogen om conform budget, planning of richtlijnen te werken.

\section{Figuur 2.3}

Trend in vereist niveau geselecteerde competenties (uitsluitend afgestudeerden werkzaam in kerndomein)

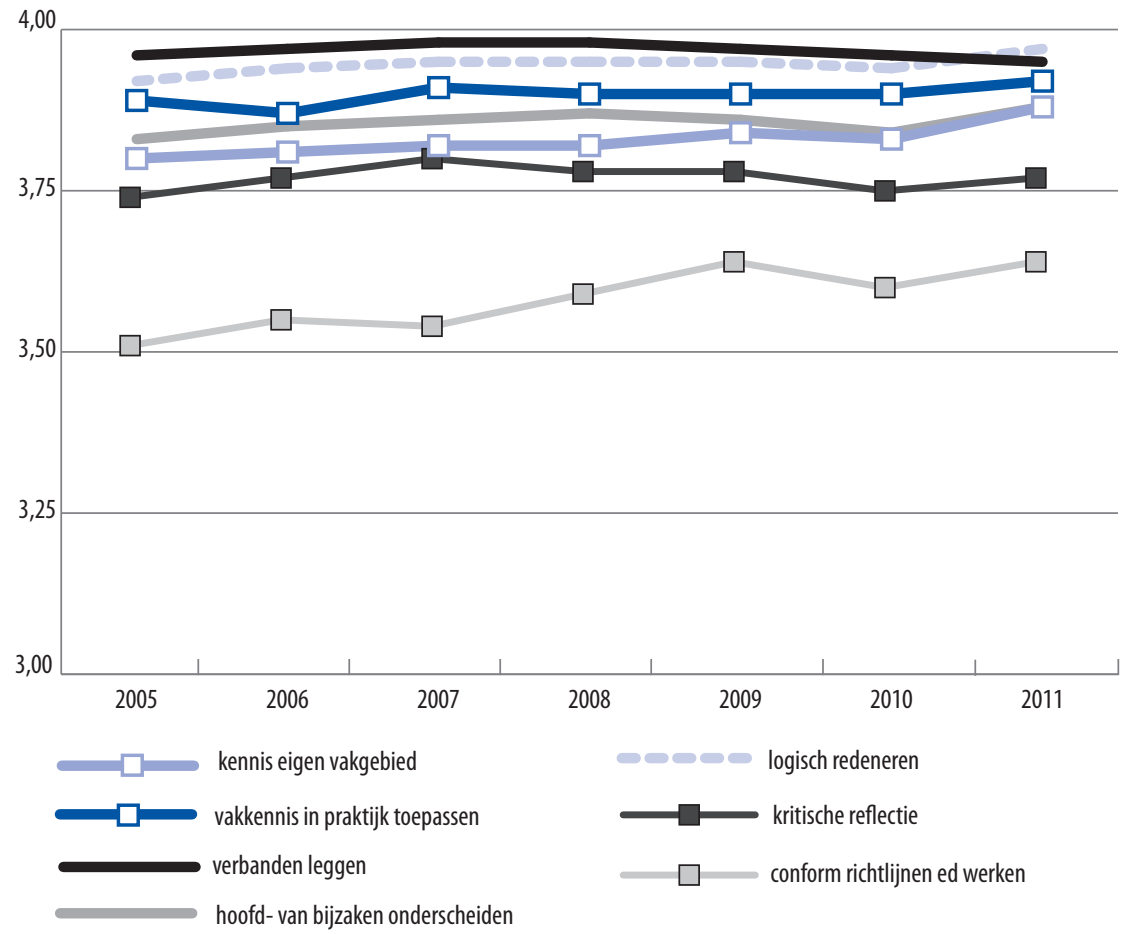

Bron: HBO-Monitor, 2005-2011 
De meeste van deze competenties worden op een tamelijk hoog niveau vereist. Dit geldt vooral voor academische vaardigheden zoals het vermogen om verbanden te leggen en het vermogen om logisch te redeneren. Kennis van eigen vakgebied blijkt op een iets minder hoog niveau te zijn vereist, evenals kritische reflectie en vooral het vermogen om conform budget, planning of richtlijnen te werken. Het vermogen om vakkennis toe te passen en het vermogen om hoofd- van bijzaken te onderscheiden nemen een middenpositie in.

Wat vooral opvalt in figuur 2.3 is de sterke stijging in het vereist niveau van het vermogen om conform budget, planning of richtlijnen te werken. Verder lijkt - op een mogelijke lichte stijging in het vereist niveau van kennis van het eigen vakgebied na - vooralsnog geen sprake te zijn dat het benodigde niveau van professionele competenties aan het stijgen is. Gegeven het feit dat het gemiddeld vereist niveau al tamelijk hoog lag is dit niet erg verwonderlijk. Professionele expertise is altijd belangrijk geweest, en blijft onverminderd belangrijk.

\section{Figuur 2.4}

Trend in vereist niveau geselecteerde competenties (uitsluitend afgestudeerden werkzaam op minimaal niveau maar buiten de eigen opleidingsrichting)

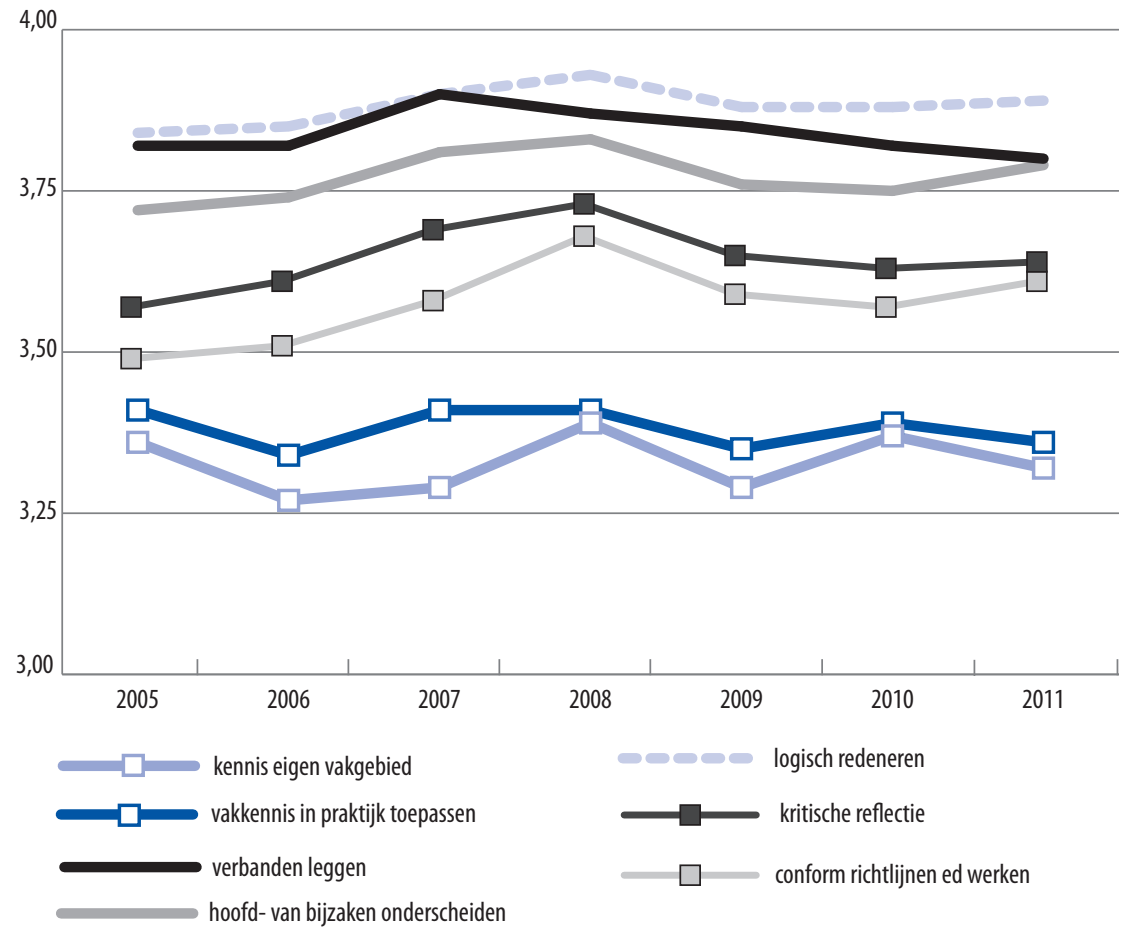

Bron: HBO-Monitor, 2005-2011 
Hoe zit het met het vereist niveau van deze competenties voor afgestudeerden die buiten hun kerndomein werken, maar nog op HBO-niveau? Dat wil zeggen: voor afgestudeerden die in banen werken waarvoor minimaal een HBO-diploma werd vereist, maar niet binnen de eigen of een verwante richting? Figuur 2.4 geeft hiervan een beeld.

Hoewel in vrijwel alle gevallen het vereist niveau van deze competenties op een lager niveau ligt wanneer de baan buiten de eigen richting valt, geldt dit het meest voor kennis van het eigen vakgebied en het vermogen om deze vakkennis toe te passen. Dit ligt nogal voor de hand: wanneer men in een baan werkt die niet aansluit bij de gevolgde opleiding, is het logisch dat een lager niveau van in deze opleiding opgedane kennis in de functie wordt vereist. Voor meer academische competenties is het verschil echter veel kleiner, en voor het vermogen om conform richtlijnen e.d. te werken is zelfs helemaal geen verschil van betekenis. Deze competenties lijken derhalve een meer generieke component van het begrip professionele expertise te weerspiegelen.

\section{Worden HBO'ers voldoende voorbereid?}

Voor HBO-instellingen en hun afgestudeerden is de relevante vraag in hoeverre het eigen niveau van de afgestudeerden voldoet aan de eisen vanuit het werkveld in termen van professionele expertise. Met andere woorden: in hoeverre gaat een hoog vereist niveau gepaard met sterke tekorten van de betreffende competenties? Figuur 2.5 geeft dit aan voor afgestudeerden die werkzaam zijn binnen hun eigen kerndomein.

Ondanks het feit dat het de academische competenties zijn die op een hoger niveau worden vereist, zijn de sterkste tekorten te zien in kennis van het eigen vakgebeid. Ruim een derde van alle HBO-afgestudeerden die binnen hun eigen kerndomein werkzaam zijn geeft aan over een lager niveau van vakkennis te beschikken dan in hun functie wordt vereist. Meer dan een kwart ervaart een tekort aan het vermogen om vakkennis in de praktijk toe te passen, het vermogen om hoofd- van bijzaken te onderscheiden, het vermogen om verbanden te leggen, en het vermogen om conform richtlijnen e.d. te werken. Een iets lager percentage geeft aan een tekort te ervaren in kritische reflectie, hoewel dit percentage tussen 2005 en 2008 enigszins is toegenomen. De minste tekorten worden ervaren in het vermogen om logisch te redeneren. Behalve de al genoemde lichte stijging in tekorten aan kritische reflectie, is de enige verandering in de tijd een mogelijk lichte afname in het percentage met een tekort aan vakkennis. 
Figuur 2.5

Trend in tekorten van geselecteerde competenties (uitsluitend afgestudeerden werkzaam in kerndomein)

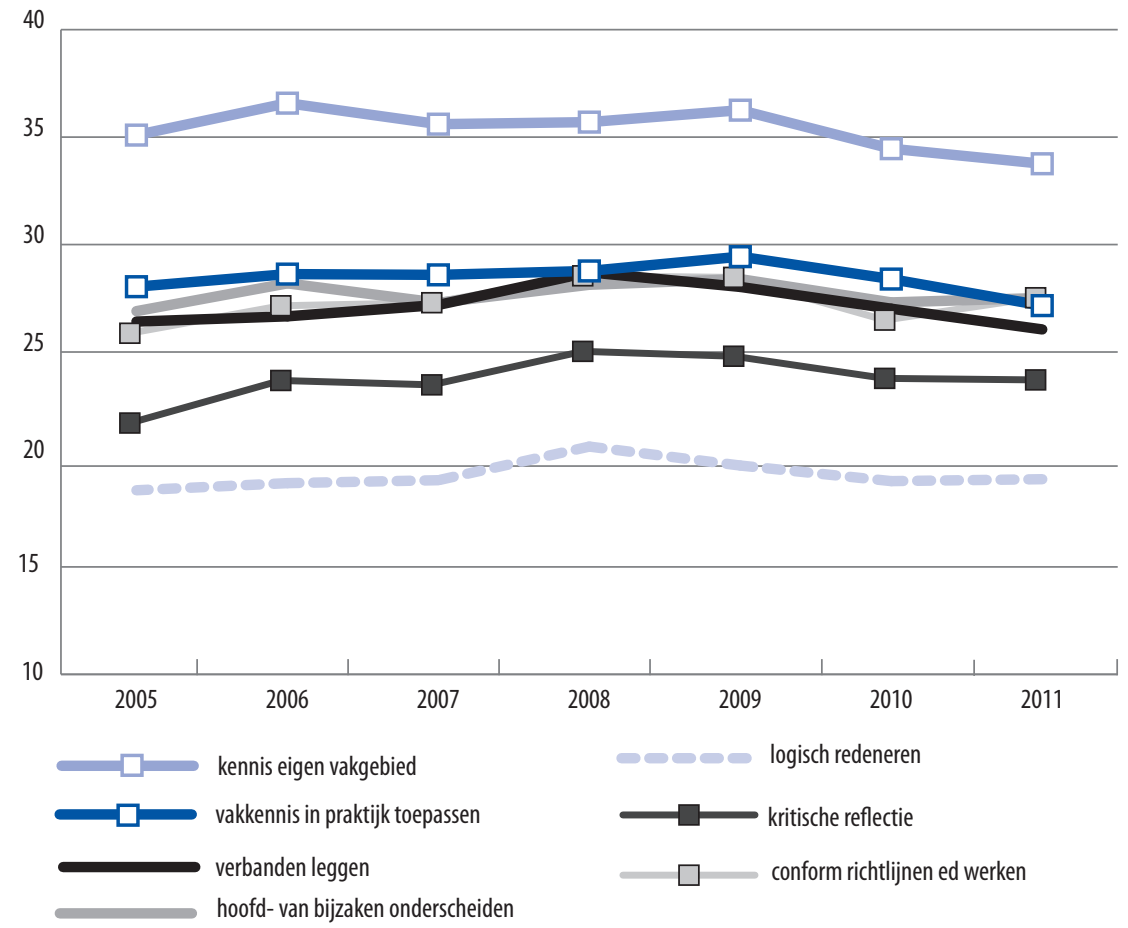

Bron: HBO-Monitor, 2005-2011

\section{Wat betekent een tekort aan vakkennis?}

Hoe erg is het om een tekort aan vakkennis te hebben? Om hier een beeld van te geven wordt hier gekeken naar een aantal kenmerken van afgestudeerden die wel en afgestudeerden die geen tekort aan vakkennis ervaren (figuur 2.6). De horizontale as geeft het verschil weer tussen het vereiste niveau en het eigen niveau. Daarbij kan alles aan de linkerkant van de waarde 'o' gezien worden als een tekort, terwijl alles aan de rechterkant van 'o' een surplus is. Uit de figuur blijkt dat recent afgestudeerden het meest gunstig over de aansluiting oordelen wanneer er geen verschil bestaat tussen het eigen en het vereiste niveau. Dit is in lijn met de verwachtingen. Carrièremogelijkheden en baantevredenheid zijn het laagst bij een surplus aan vakkennis. Bij een tekort aan vakkennis zijn er zelfs betere carrièremogelijkheden dan wanneer het eigen en het vereiste niveau precies in balans zijn. Iets soortgelijks geldt voor baantevredenheid. Afgestudeerden met een licht tekort zijn iets tevredener dan afgestudeerden waarbij het eigen en het vereiste niveau in evenwicht zijn, en zelfs ernstige tekorten lijken nauwelijks invloed te hebben op tevredenheid met de baan. Kortom: opleidingen 
kunnen de tevredenheid met de aansluiting verhogen door tekorten te reduceren. De baantevredenheid lijkt echter niet onder tekorten te lijden. Dit komt omdat een tekort doorgaans een indicatie is van dynamisch en uitdagend werk.

\section{Figuur 2.6}

Kenmerken voor afgestudeerden met een tekort dan wel surplus aan vakkennis, 2005-2011 (gepoolde data; uitsluitend afgestudeerden werkzaam in kerndomein)

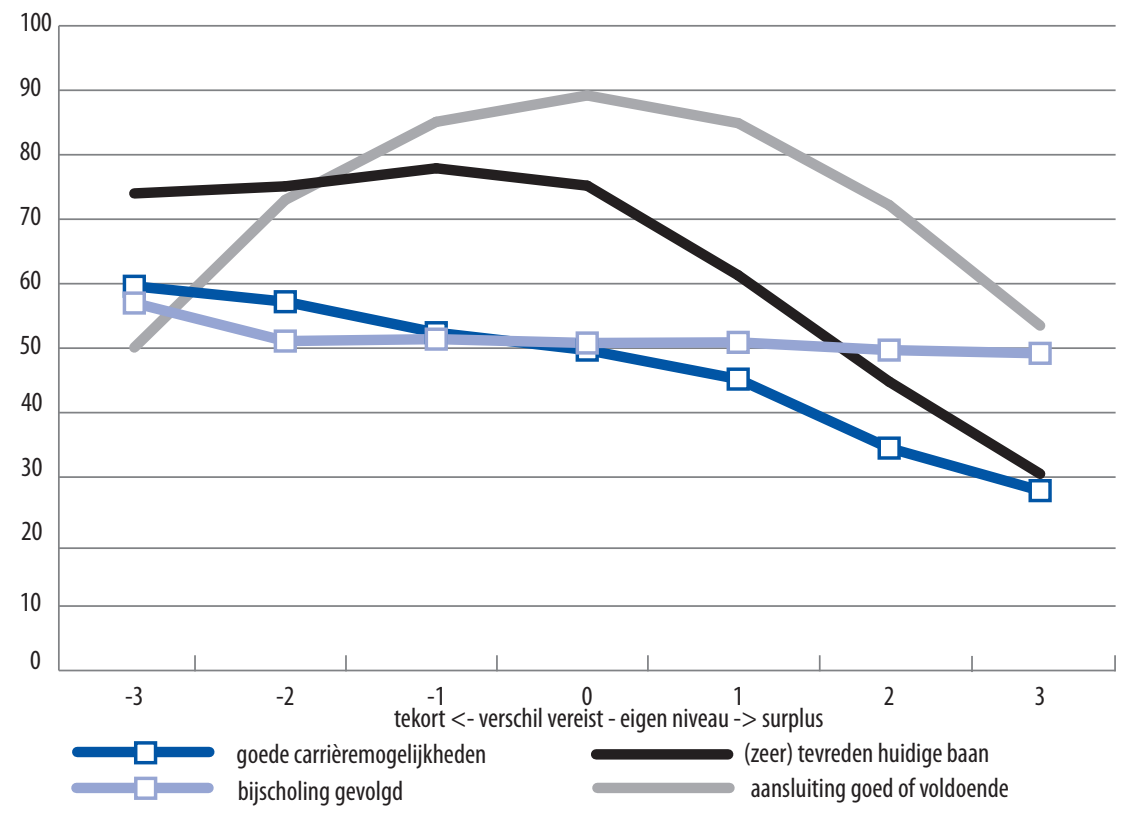

Bron: HBO-Monitor, 2005-2011

Qua bijscholing kan geconcludeerd worden dat er iets meer aan bijscholing wordt gedaan bij een ernstig tekort aan vakkennis, maar dit houdt niet over. Werkgevers hebben ook een verantwoordelijkheid om tekorten te reduceren, vooral gezien de snel veranderende vereisten. $\mathrm{Nu}$ wordt er nauwelijks meer aan bijscholing gedaan bij afgestudeerden met een tekort aan vakkennis dan bij degenen waarbij de vakkennis in balans is of die een surplus hebben. In theorie zou het natuurlijk kunnen zijn dat investeringen in bijscholing juist de tekorten hebben gereduceerd. Onderzoek van Allen en De Grip (2012) toont echter aan dat tekorten doorgaans een structureel karakter hebben: zodra oude tekorten door middel van scholing zijn opgeheven ontstaan nieuwe tekorten in hun plaats.

Een soortgelijke analyse is verricht voor de beloning van recent afgestudeerden. Figuur 2.7 laat de beloning zien van recente afgestudeerden met een tekort aan vakkennis, een surplus aan vakkennis en degenen waarbij het vereist niveau en het eigen niveau in balans zijn. Duidelijk is dat de beloning het hoogst is als het eigen en vereist niveau in 
evenwicht zijn, of als er sprake is van een lichte surplus. Zowel tekorten als een groter surplus hangt samen met een lager loon.

\section{Figuur 2.7}

Bruto uurloon afgestudeerden met een tekort dan wel surplus aan vakkennis, 2005-2011 (gepoolde data; uitsluitend afgestudeerden werkzaam in kerndomein)

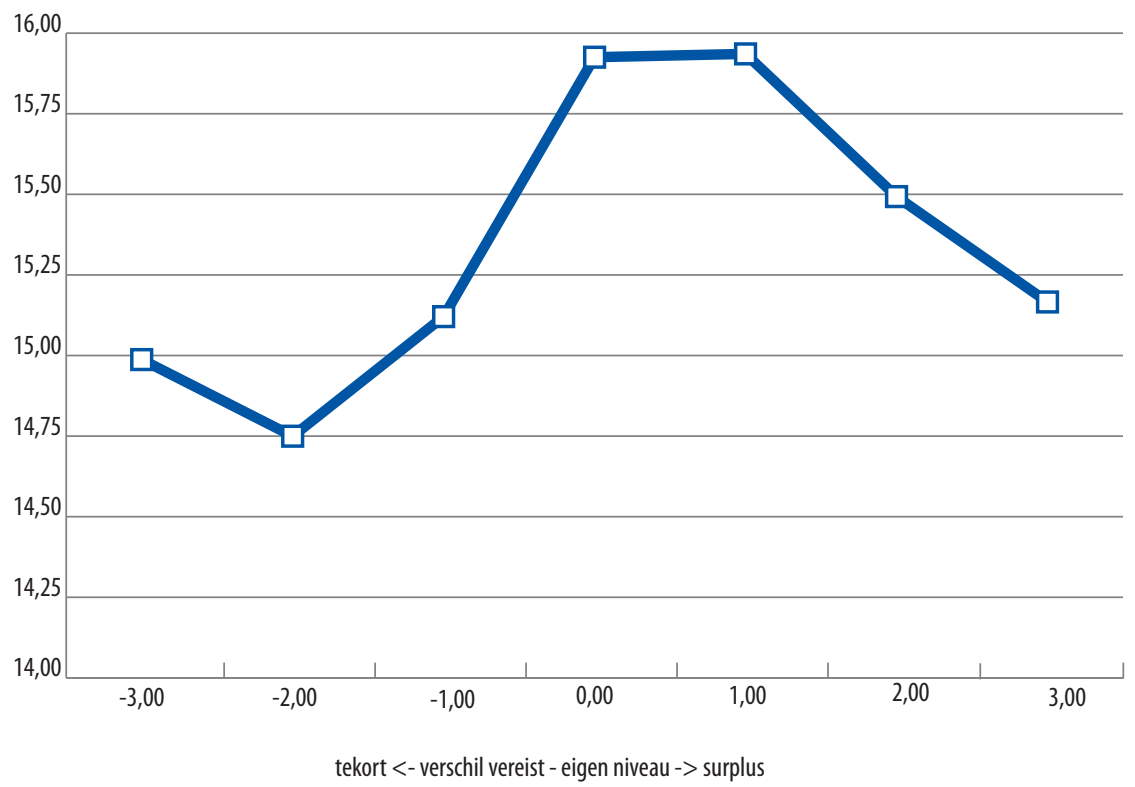

Bron: HBO-Monitor, 2005-2011

Samenvattend kan worden geconcludeerd dat zowel tekorten als surplussen in vakkennis resulteren in een lagere beloning. Wellicht mede hierdoor leggen afgestudeerden een verband tussen dergelijke mismatches en het oordeel over de aansluiting tussen de HBO-opleiding en hun werk. Voor wat betreft andere indicatoren van baankwaliteit blijkt echter dat lichte tekorten geen echt probleem vormen, en voor wat betreft de gepercipieerde carrièremogelijkheden zelfs een licht voordeel opleveren. Dit lijkt een bevestiging te geven dat tekorten tot op zekere hoogte een indicatie zijn van een dynamische en uitdagende werkomgeving. Vanuit dat oogpunt lijkt het niet geheel terecht om hogescholen het hoge percentage afgestudeerden met een tekort aan vakkennis zonder meer aan te rekenen. Wanneer een hoog percentage afgestudeerden erin slaagt om zulk uitdagend werk te vinden, kan dit zelfs deels worden gezien als een teken van succes. Dit neemt niet weg dat het van groot belang is dat hogescholen zich blijven inspannen om de tekorten aan vakkennis zo laag mogelijk te houden. Dit geldt te meer omdat als afgestudeerden eenmaal aan het werk zijn, tekorten nauwelijks een prikkel lijkt te vormen voor hen of hun werkgevers om in nadere scholing te investeren. 
Het feit dat de meeste HBO-Monitor respondenten slechts een deel van de weg hebben afgelegd om expert te worden op hun vakgebied, is reden om de aandacht te vestigen op het feit dat de $\mathrm{HBO}$-opleiding een voorbereiding kan vormen voor deelname aan de arbeidsmarkt zowel op de korte als de langere termijn. De korte termijn doelstelling wordt weerspiegeld in het oordeel van afgestudeerden over de opleiding als basis om te starten op de arbeidsmarkt. Figuur 2.8 laat het percentage afgestudeerden dat hierover (zeer) tevreden is, voor verschillende mate van tekort, evenwicht of surplus van zes competenties die aan professionele expertise gerelateerd zijn.

\section{Figuur 2.8}

Percentage dat de opleiding een goede basis vond om op de arbeidsmarkt te starten, voor afgestudeerden met een tekort dan wel surplus aan geselecteerde competenties, 2005-2011 (gepoolde data; uitsluitend afgestudeerden werkzaam in kerndomein)

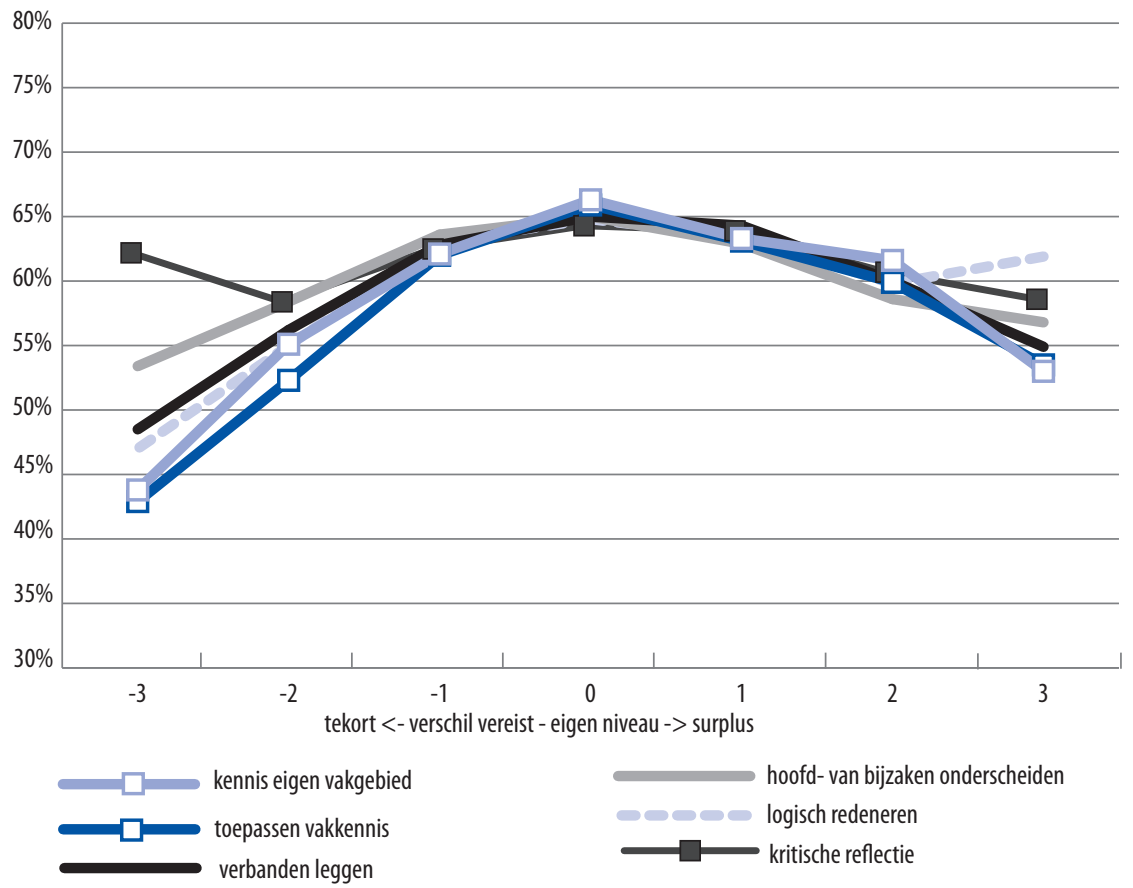

Bron: HBO-Monitor, 2005-2011

Zoals we zouden verwachten is men het meest positief hierover wanneer het eigen en het vereist niveau in evenwicht zijn, en neemt het af naarmate het eigen niveau meer tekort schiet. Opvallend hierbij is dat dit het meest geldt voor vakkennis en het vermogen om vakkennis in de praktijk toe te passen. Hoewel tekorten van de meer academische competenties ook met een vermindering in tevredenheid op dit punt 
gepaard gaan, is dit minder dan bij de kennisitems. Dit geldt, zij het iets minder geprononceerd, voor een surplus. We zouden ons natuurlijk kunnen afvragen waarom een surplus sowieso tot ontevredenheid op dit punt zou moeten leiden. Vermoedelijk wordt een surplus de opleiding aangerekend omdat het dan om een investering gaat die beter aan andere competenties had kunnen worden besteed.

Figuur 2.9 geeft het verband weer van mismatches op deze competenties en het oordeel over het lange-termijn doel van de opleiding: in hoeverre het een goede basis vormde voor het verder ontwikkelen van kennis en vaardigheden.

\section{Figuur 2.9}

Percentage dat de opleiding een goede basis vond om verder te leren, voor afgestudeerden met een tekort dan wel surplus aan geselecteerde competenties, 2005-2011 (gepoolde data; uitsluitend afgestudeerden werkzaam in kerndomein)

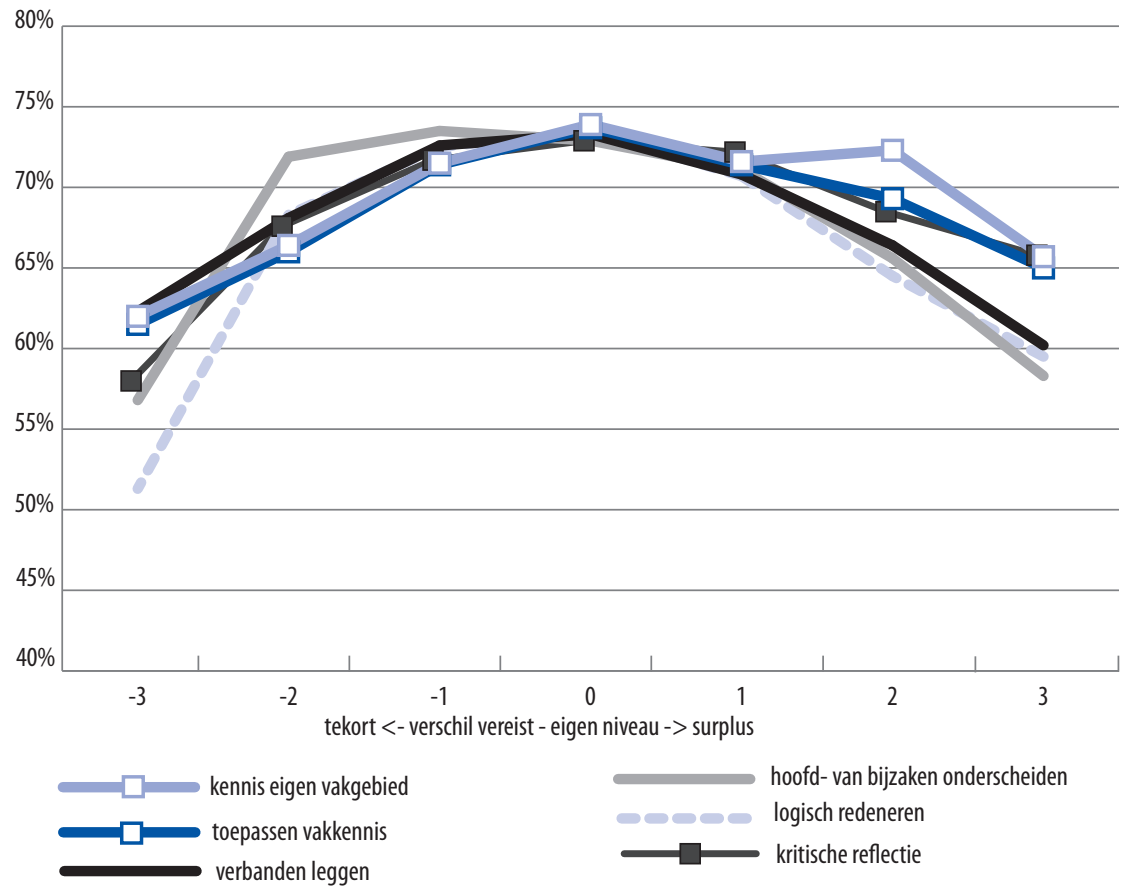

Bron: HBO-Monitor, 2005-2011

Op het eerste gezicht lijken de twee figuren sterk op elkaar, maar bij nader inzien zijn er belangrijke verschillen. Ten eerste blijkt bij een goede match de tevredenheid met de opleiding op dit punt fors hoger: zo'n driekwart van de afgestudeerden vindt bij een goede match dat de opleiding een goede basis vormde voor het verder ontwikkelen van kennis en vaardigheden, tegenover zo'n twee derde bij het oordeel over de opleiding als basis om te starten. Ten tweede worden juist tekorten op de academische vaardigheden de opleiding het zwaarst aangerekend. Met andere woorden: het zijn 
vooral tekorten op academische vaardigheden die als belemmering worden gezien voor verdere kennisontwikkeling.

\section{Tekstbox 2.1}

Sectorspecifieke uitdagingen van de kennissamenleving

De uitdagingen van de kennissamenleving kennen natuurlijk vaak een sectorspecifiek karakter. Zo blijken de Pabo's en lerarenopleidingen in het recente verleden ernstig tekort te zijn geschoten op rekenen en taalbeheersing. Voor de lerarenopleidingen zijn er daarom in 2009 kennisbases ontwikkeld, welke de basiskwaliteit van de lerarenopleidingen garanderen. De Pabo's hebben het afgelopen jaar de kennisbases voor de vakken rekenen-wiskunde en Nederlandse taal vastgelegd. Voor de tweedegraads lerarenopleidingen bestaat de kennisbasis per schoolvak voor $50 \%$ uit vakkennis (bijvoorbeeld Frans of Wiskunde) en voor 50\% uit praktijkkennis (bijvoorbeeld pedagogiek, didactiek en praktijkstages) (HBO-raad, 2010). Begin 2012 is besloten dat bij Pabo's bovendien meer aandacht zal worden besteed aan het toetsen van kennis en vaardigheden van Engels, geschiedenis, aardrijkskunde en natuur en techniek (ANP, 2012). Ook moeten studenten zich tijdens en na hun studie specialiseren.

In de zorg en welzijn sectoren gelden weer andere uitdagingen. De zorg wordt in toenemende mate geprivatiseerd. Door de marktwerking in de sector zorg en welzijn wordt het leveren van diensten steeds meer beschouwd als een productieproces waarin professionele organisaties en professionals input leveren en afgerekend worden op hun output. Om de kwaliteit van de geboden diensten te meten en te verbeteren wordt er steeds meer met protocollen en standaardformulieren gewerkt. De toenemende verzakelijking leidt ook tot een verregaande opdeling in functies en verantwoordelijkheden (van der Laan et al, 2003). Dit heeft mogelijke consequenties voor de grenzen tussen HBO functies in de zorg en functies op andere niveaus, met name op MBO-niveau (van Vliet et al, 2004, p20). Verzakelijking en toenemende marktwerking beperken ook de handelingsruimte van professionals in de sector. Deze handelingsruimte wordt enerzijds beperkt door de noodzaak van doelmatigheid en protocollering, en anderzijds door de vraag van cliënten, zorgverzekeraars en financiers (van Vliet et al, 2004, p22; Scherpbier et al, 2010, p6). Daarnaast is er sprake van extramuralisering van de zorg, wat inhoudt dat het aantal gebruikers van thuiszorg de komende decennia zal stijgen en het aantal mensen dat in verzorgings- of verpleegtehuizen verblijft zal dalen (Ministerie van VWS, 2007, p49). 
Van de zes door Humburg en Van der Velden genoemde sociale en economische ontwikkelingen, is de ICT-revolutie volgens hen het meest nauw verweven met de andere vijf. De toenemende invloed van ICT op vrijwel alle terreinen vormt de belangrijkste motor voor de hedendaagse kennissamenleving, en ook van de globalisering, de verandering van de economische structuur en het ontstaan van highperformance organisaties, maar ook van toenemende onzekerheid door de vergaande veranderingen in markten.

Zoals Hage en Powers (1992) opmerken, is ICT geen homogeen verschijnsel, met gelijke effecten op alle fronten. Ze maken een onderscheid tussen instrumenten, die tot een toename in het aantal en complexiteit van de te verrichten taken, en andere machines, die vooral gebruikt worden om arbeid te vervangen of te vereenvoudigen. Humburg en Van der Velden merken op dat het eerstgenoemde effect dominant is, vooral wat betreft kenniswerk (zie ook Levy 20I0). Hoewel instrumenten ook een deel van het werk van kenniswerkers overneemt en vervangt, is het belangrijkste effect hiervan dat meer tijd wordt vrijgemaakt voor deze kenniswerkers om de ruimere mogelijkheden die hierdoor ontstaan in te zetten voor nieuwe en meer complexe productiemogelijkheden. $\mathrm{Zij}$ behouden de regie. Dit ligt anders voor meer routinewerk met veel herhaling van dezelfde handelingen. Voor dergelijk werk wordt ICT vooral ingezet om het werk van mensen over te nemen of te vereenvoudigen.

Het recente Horizon Report (Johnson e.a. 20Io) gaat iets dieper in op de nieuwste ICT-ontwikkelingen, en de nieuwe uitdagingen die hiervan het gevolg zijn. Ze wijzen op de ongekende variëteit aan hulpbronnen, relaties, e.d. die tegenwoordig vrij toegankelijk zijn voor allen die verbonden zijn met het internet. Hierdoor is veel meer flexibiliteit mogelijk voor wat betreft de tijd en plaats van werk, studie en andere activiteiten, wordt samenwerking op afstand veel gemakkelijker, en kan kennis en informatie veel sneller en efficiënter worden opgeslagen, verspreid en gebruikt.

Vooral de nieuwste ontwikkelingen op het gebied van mobiele apparaten baart opzien, waarbij innovaties zoals het vermogen om direct en intelligent op de gebruiker en zijn/haar omgeving te reageren tot een explosie in de gebruiksmogelijkheden van deze apparaten lijkt te kunnen leiden. In toenemende mate worden deze apparaten een verlengstuk van de gebruiker, en worden ze vanzelfsprekend gebruikt om dagelijkse problemen op het werk en in het dagelijkse leven op te lossen. 
Verder wijzen de auteurs op de effecten van de enorme hoeveelheid informatie die via internet beschikbaar wordt gesteld. Zoals in paragraaf 2 al is aangegeven, snijdt dit mes aan twee kanten. Enerzijds maakt deze ontwikkeling het mogelijk voor bedrijven en organisaties om vrijwel onbeperkt kennis en informatie in te zetten voor productieve doeleinden, en niet meer alleen de kennis en informatie die ze fysiek in huis hebben. De keerzijde hiervan is echter dat alle andere bedrijven en organisaties - dus ook de concurrenten - over dezelfde informatie beschikken, waardoor het niet meer een kwestie is van kunnen, maar eerder van moeten.

Cijfers van het CBS laten zien hoe snel de ICT-revolutie in Nederland heeft plaatsgevonden:

\section{Figuur 3.1}

Ontwikkeling ICT-gebruik bij Nederlandse bedrijven, 1995-20091)

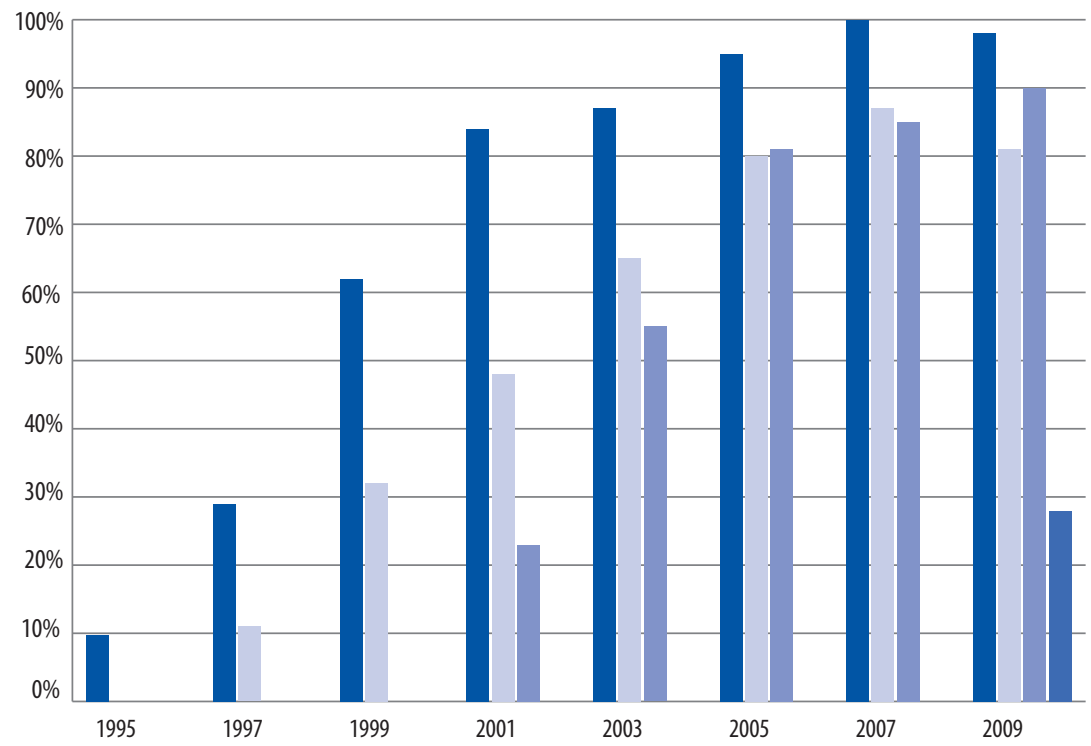

internet

breedbandinternet

website

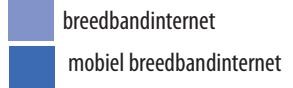

Bron: CBS, ICT-gebruik bedrijven/Automatiseringsenquête.

Noten:

1) Bedrijven met tien en meer werknemers (1995-2001)/werkzame personene (2003-2009).

2) Breedbandinternet is hier gedefinieerd als ADSL, kabel en andere vaste hoogwaardige internetverbindingen zoals glasvezel.

3) Naar gebruik van mobiel breedbandinternet is in 2009 voor het eerst gevraagd.

Halverwege de jaren negentig was nog geen tien procent van de Nederlandse bedrijven met het internet verbonden. Viertien jaar later waren vrijwel alle bedrijven online, en had ruim acht op de tien zelfs een eigen website. In 2009 bleek ruim een kwart van de 
bedrijven gebruik te maken van mobiel breedbandinternet. Internet is zo vanzelfsprekend geworden voor de meeste bedrijven als telefoon en stroom.

Natuurlijk betekent een internetverbinding niet dat alle werknemers van een bedrijf hiermee werken, of dat alle bedrijven internet - en ICT in het algemeen - voor dezelfde doeleinden gebruiken. De volgende tabel laat verschillende indicatoren van ICT gebruik zien, uitgesplitst naar bedrijfstak.

\section{Tabel 3.1}

ICT-gebruik per branche, 2010

\begin{tabular}{|c|c|c|c|}
\hline & $\begin{array}{l}\text { \% personeel } \\
\text { gebruikt computer }\end{array}$ & $\begin{array}{r}\% \text { personeel } \\
\text { gebruikt mobiel } \\
\text { internet }\end{array}$ & $\begin{array}{l}\text { \% bedrijven } \\
\text { gebruikt ICT voor } \\
\text { orderverwerking }\end{array}$ \\
\hline Voedings-, genotmiddelenindustrie & 49 & 5 & 50 \\
\hline Raffinaderijen en chemie & 85 & 6 & 57 \\
\hline Elektrische en elektron. Industrie & 81 & 6 & 61 \\
\hline Machine-industrie & 69 & 6 & 50 \\
\hline B\&U en wegenbouw & 49 & 8 & 45 \\
\hline Groothandel en handelsbemiddeling & 75 & 17 & 60 \\
\hline Detailhandel (niet in autos) & 51 & 4 & 47 \\
\hline Vervoer en opslag & 54 & 6 & 55 \\
\hline Logiesverstrekking & 55 & 6 & 47 \\
\hline Eet- en drinkgelegenheden & 34 & 8 & 50 \\
\hline Uitgeverijen, film,radio en t.v. & 93 & 15 & 69 \\
\hline Telecommunicatie & 34 & 11 & 72 \\
\hline IT- en informatiedienstverlening & 99 & 41 & 76 \\
\hline Banken & 99 & 18 & 43 \\
\hline Verhuur en handel van onroerend goed & 94 & 20 & 61 \\
\hline Juridisch en managementadvies & 94 & 31 & 53 \\
\hline Architecten-, ingenieursbureaus e.d. & 93 & 24 & 62 \\
\hline Reclamewezen en marktonderzoek & 90 & 20 & 65 \\
\hline Ontwerp, overige consultancy & 83 & 16 & 61 \\
\hline Uitzendbureaus en arbeidsbemiddeling & 84 & 13 & 54 \\
\hline Reisbureaus, reisorganisatie en -info & 98 & 8 & 71 \\
\hline Overige zakelijke dienstverlening & 31 & 5 & 52 \\
\hline Gezondheidszorg & 86 & 7 & 60 \\
\hline Verzorging en welzijn & 57 & 5 & 55 \\
\hline
\end{tabular}

$\mathrm{Er}$ is een groot verschil in mate van ICT gebruik, zowel naar indicator als naar branche. Over de hele linie blijkt dat een tamelijk hoog percentage personeel gebruik makkt van een computer, hoewel er branches zijn waar dat veel minder het geval is. Veel minder prevalent - maar mogen we aannemen snel aan het toenemen - is het percentage personeel dat mobiel internet gebruikt. In de meeste branches was het in 2010 nog uitzonderlijk dat personeel deze technologie in hun werk gebruikte, maar er zijn enkele branches waar het vaker voorkomt. Een tamelijk hoog percen- 
tage bedrijven gebruikt ICT voor orderverwerking, in verreweg de meeste branches boven de 50\%. Hierbij dient te worden opgemerkt dat het hierbij om een indicator op bedrijfsniveau gaat.

Wanneer we naar de afzonderlijke branches kijken, zien we dat sommige branches hoog scoren op alle drie indicatoren. Zoals zou worden verwacht geldt dit voor IT- en informatiedienstverlening, maar ook Verhuur en handel van onroerend goed, Architecten-, ingenieursbureaus e.d., en Reclamewezen en marktonderzoek tonen een hoge mate van ICT-gebruik volgens alle drie indicatoren. Daartegenover staat een aantal branches - Voedings-, genotmiddelenindustrie, Detailhandel, Logiesverstrekking en Overige zakelijke dienstverlening - waar alle vormen van ICT-gebruik op een tamelijk laag niveau zitten. Tenslotte is er een aantal branches die hoog scoren op een bepaalde indicator maar laag op andere. Zo gebruikt een verassend laag percentage personeel in de Telecommunicatie branche een computer, terwijl deze branche het hoogste percentage bedrijven toont dat ICT gebruikt voor orderverwerking. Bij banken is ongeveer het omgekeerde het geval. Algemeen geldt dat het gebruik van ICT voor orderverwerking weinig verband vertoont met de andere ICT-indicatoren, tenminste op branche-niveau. Het gaat hier om een tamelijk specifiek vorm van ICT-gebruik, dat zich goed leent voor een nogal gestandaardiseerd aanpak.

\section{Figuur 3.2}

Vereist niveau per competentiecluster, naar niveau van ICT-gebruik per branche

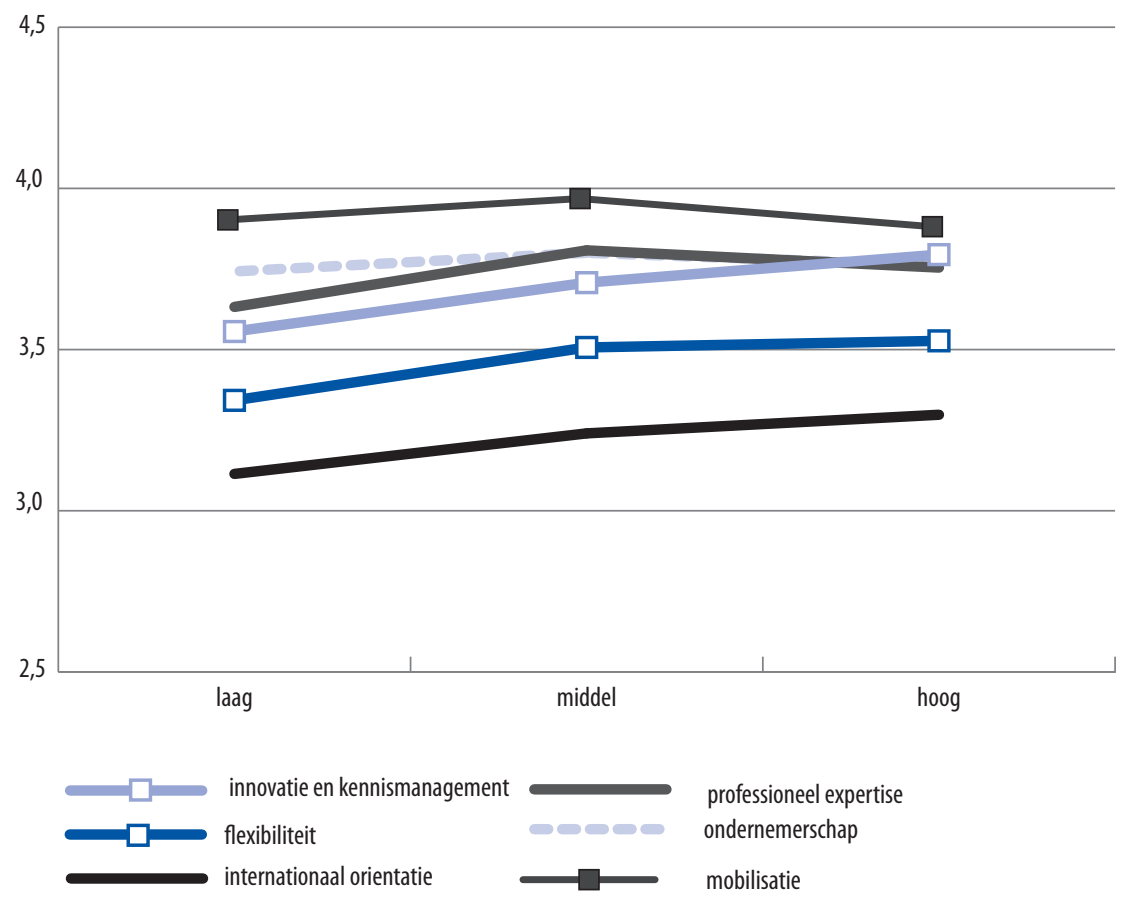

Bron: HBO-Monitor, 2005-2011 
Door CBS data via branche codes te koppelen aan data uit de HBO-Monitor kunnen we een beeld krijgen van hoe het niveau ICT-gebruik in een branche zich vertaalt in competentievereisten. Figuur 3.2 geeft aan hoe het gemiddeld vereist niveau per breed competentiecluster varieert met het aandeel werknemers in een branche dat met een computer werkt. Hierbij is voor het gemak een onderscheid gemaakt tussen drie min of meer gelijk verdeelde niveaus: laag gebruik ( $<=55 \%)$, middelbaar gebruik $(56-85 \%)$ en hoog gebruik (>85\%).

Hoewel innovatie en kennismanagement competenties niet het hoogst scoren, zelfs in branches met een hoog niveau van ICT-gebruik, is dit het cluster waar het verschil tussen laag, middelbaar en hoog gebruik het meest geprononceerd is. Nadere analyses (niet opgenomen in dit figuur) laten zien dat dit verband alleen geldt voor twee van de drie onderliggende competenties voor dit cluster, te weten het vermogen om ICT te gebruiken en het vermogen om informatie te vergaren. Er blijkt geen verband te zijn met de derde competentie, het vermogen om nieuwe ideeën en oplossingen te bedenken.

Figuur 3.3

Trend in vereist niveau geselecteerde competenties (uitsluitend afgestudeerden werkzaam in kerndomein)

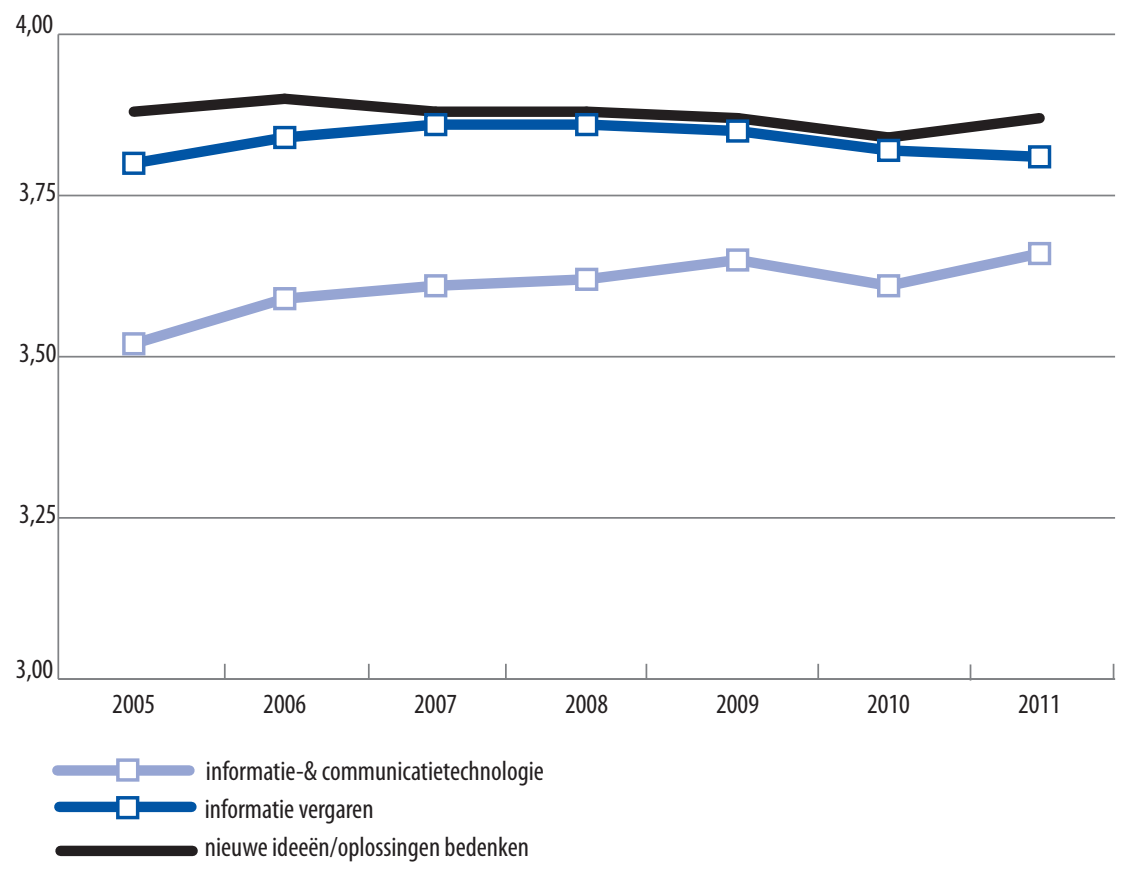

Bron: HBO-Monitor, 2005-2011 
Flexibiliteit en internationale oriëntatie blijken ook tamelijk sterk met ICT-gebruik samen te hangen. Gezien het feit dat werken met een computer meestal ook werken op internet impliceert, ligt het verband met internationale oriëntatie voor de hand. Internet fungeert immers als een soort toegangspoort naar de wereld. Hoewel het moeilijk is om de causaliteitsrichting te ontrafelen - maken mensen vaker gebruik van internet omdat ze sterk gericht zijn op de internationale economie, of worden ze juist onder invloed van het gebruik van het internet sterker internationaal georienteerd - valt niet te ontkennen dat deze zaken vaak samengaan. De ICT-revolutie wordt immers gezien als een van de belangrijkste drijfveren van de globalisering. Het verband met flexibiliteit - bestaande uit de competenties het vermogen om nieuwe dingen te leren en kennis van andere vakgebieden - is minder vanzelfsprekend, maar ook hier ligt de oorzaak in de mogelijkheden die het internet verschaft om toegang tot uiteenlopende informatie te verschaffen.

\section{Figuur 3.4}

Trend in vereist niveau geselecteerde competenties (uitsluitend afgestudeerden werkzaam op minimaal niveau maar buiten de eigen opleidingsrichting)

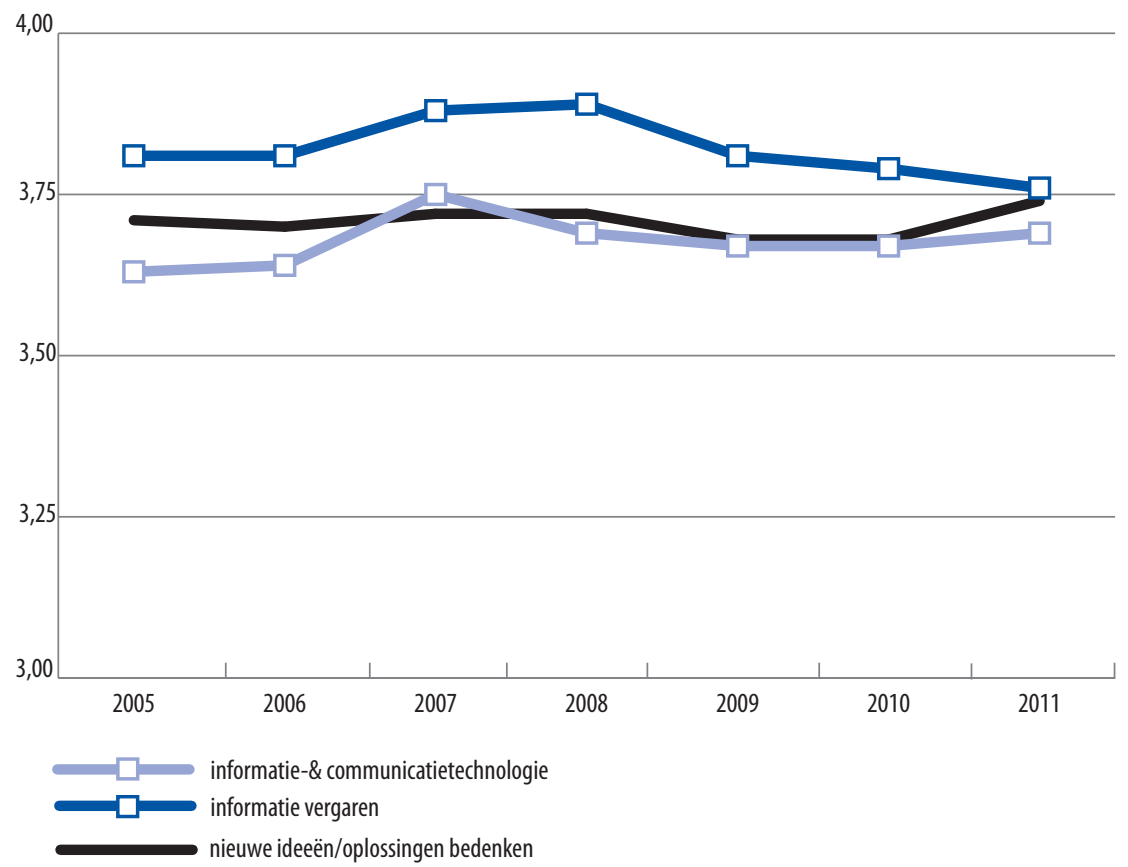

Bron: HBO-Monitor, 2005-2011 
Hoe zit het met het vereist niveau van deze competenties in de tijd? Zijn er indicaties dat de ICT revolutie tot een verhoging van het vereiste niveau van competenties die erelateerd zijn aan innovatie en kennismanagement? Figuur 3.3 geeft hiervan een beeld, voor afgestudeerden werkzaam binnen hun kerndomein.

Figuur 3.3 laat duidelijk zien dat het vereist niveau van ICT-competenties sinds 2005 merkbaar is gestegen voor afgestudeerden werkzaam binnen hun kerndomein. Hoewel dit niveau in $201 \mathrm{I}$ nog lager ligt dan dat van de andere twee competenties, is het verschil beduidend kleiner geworden. Figuur 3.4 laat dit zien voor afgestudeerden die in functies werkzaam zijn waarvoor een $\mathrm{HBO}$-diploma vereist is, maar niet binnen de eigen of een verwante richting als door de respondent werd gevolgd.

Een aantal zaken vallen op in figuur 3.4. Ten eerste blijkt het vereist niveau van ICT-competenties structureel hoger te liggen dan bij mensen die in hun eigen kerndomein werken. Er is ook geen sprake van een structurele stijging in het vereiste niveau van ICT-competenties. Ten slotte lijkt er ook geen structurele trend te zijn in het vereiste niveau van de andere twee competenties.

Hoe zit het met tekorten? Wordt de stijging in het vereist niveau van ICT-competenties van diegenen die werkzaam binnen hun kerndomein zijn vertaald in een stijging in tekorten? Figuur 3.5 geeft hiervan een beeld.

Er lijkt inderdaad sprake van een stijging in tekorten van ICT-competenties, maar deze is heel licht, en het niveau van de tekorten ligt nog vrij laag, in $201 \mathrm{I}$ nog minder dan $20 \%$. Er lijkt op dit punt vooralsnog geen reden voor $\mathrm{HBO}$-instellingen om zware maatregelen te treffen om dit stijgende tekort te lijf te gaan. Dit geld te meer omdat de meeste jongeren tegenwoordig min of meer vanzelf in aanraking komen met ICT, in zowel de privésfeer als op school. Er lijkt eerder een iets andere les te trekken uit het stijgende belang van ICT, namelijk dat bestaande functies door toenemend ICT gebruik worden getransformeerd. 
HOOFDSTUK 3

Figuur 3.5

Trend in tekorten van geselecteerde competenties (uitsluitend afgestudeerden werkzaam in kerndomein)

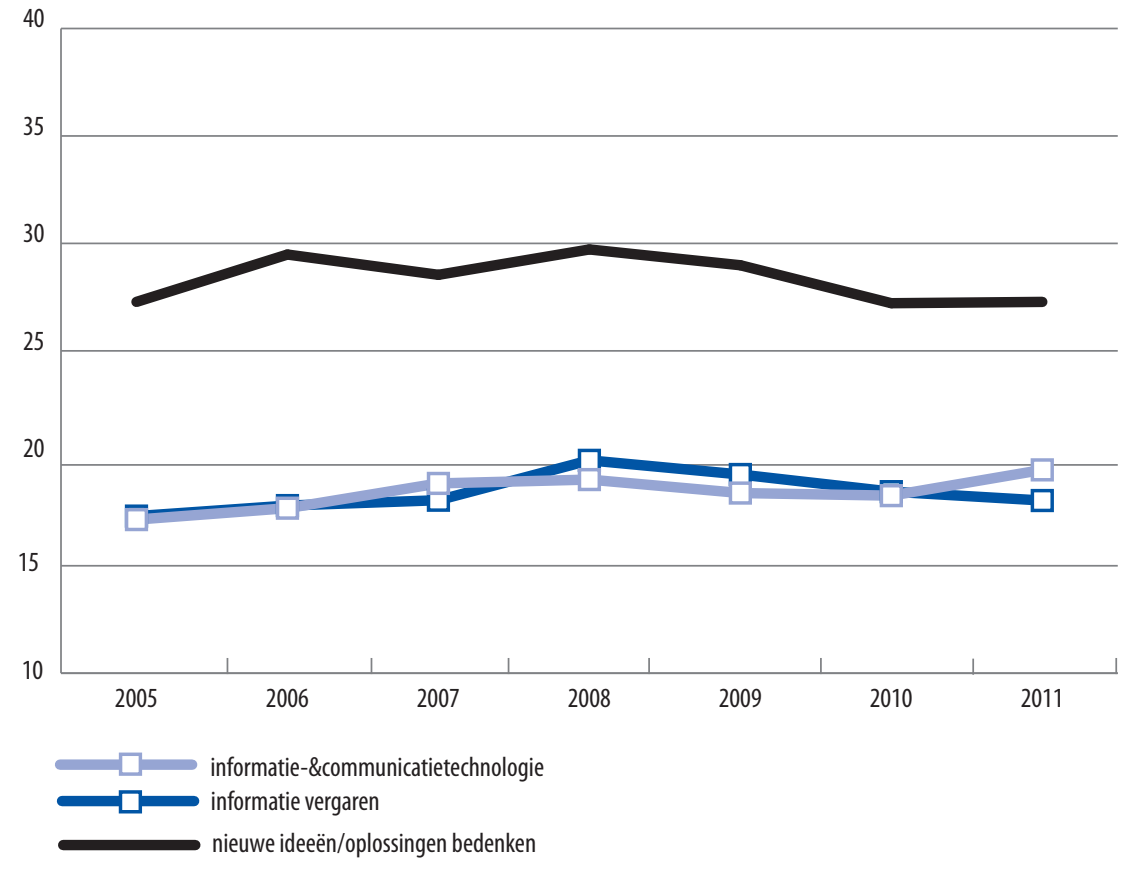

Bron: HBO-Monitor, 2005-2011 


\section{Tekstbox 3.1}

Sectorspecifieke veranderingen door de ICT-revolutie

Net als bij de kennissamenleving tonen de gevolgen van de ICT-revolutie soms een sterk sectorspecifiek karakter. In de economische sector zien we dat producten en diensten steeds vaker via internet worden aangeboden en dat daarbij ook sociale media worden ingezet (Rabobank, 2011; ABN Amro, 2011). Deze digitalisering van de dienstverlening vraagt om ICT-vaardigheden die hier speciaal op gericht zijn. De sociale media zouden daarbij als apart onderdeel aan bod kunnen komen in het onderwijs als het gaat om het ontwikkelen van communicatievaardigheden. Deze worden namelijk in toenemende mate van belang om zich te kunnen presenteren of om als informatie- of verkoopkanaal in te kunnen zetten in de communicatie naar klanten. Dit is een goed voorbeeld van hoe bestaande beroepen kunnen worden getransformeerd onder invloed van ICT. Om sociale media effectief te gebruiken in het werk is verbeterde ICT kennis waarschijnlijk niet het meest belangrijk. Eerder lijkt van belang dat men hun communicatieen presentatievaardigheden opvijzelt, om optimaal gebruik te kunnen maken van de voor het bedrijf interessante contacten die ze tegenkomen.

Bij het HPO is wellicht de grootste uitdaging voor de komende tijd hoe in te haken op de talloze manieren waarop ICT kan worden gebruikt om het onderwijs te verbeteren. De afgelopen twee decennia zijn er veel aanhangers geweest van innovatieve methoden om '21st century skills' te ontwikkelen (OECD, 2010). In Nederland wordt in de meeste (zo niet alle) programma's in het secundaire (VO en MBO) en tertiaire (HBO en W0) onderwijs een bepaalde vorm van student-gecentreerde methode gebruikt, waarbij de doelstellingen gedefinieerd zijn in competenties, en waarbij de rol van de docent die van bemiddelaar/adviseur/gids is. Door ICT is het mogelijk om persoonlijke leerplannen op te zetten die geïntegreerd worden in interactieve leeromgevingen (eventueel met een e-docent). Deze individuele leeromgevingen worden onderling met elkaar verbonden zodat het mogelijk is om samenwerkingsprojecten uit te voeren, hetgeen de mogelijkheden voor 'informeel leren' vergroot (ECJRC, 2011). Door het gebruik van moderne technologie rukken bovendien gemeenschappen van onderwijswerkers op die samen curricula ontwikkelen en ze toegankelijk maken via 'open resources'. Leraren kunnen kiezen uit materiaal dat al ergens anders ontwikkeld is. Studenten kunnen colleges volgen van de beste docenten ter wereld (Allen en Van der Velden, 2011). Toch is het aandeel leraren dat zich volledig bewust is van de didactische mogelijkheden van ICT vrij laag (Kennisnet, 2010).

Dankzij technologische en geautomatiseerde vernieuwingen in de sectoren zorg en welzijn is het mogelijk om aangepaste woningen te bouwen, geavanceerde zorg te bieden en mensen met een beperking te ondersteunen in hun dagelijks leven (Dekker e.a., 2002). Door de steeds verdergaande toename van medische kennis en technologie, samen met het toenemende opleidingsniveau van de bevolking, zal de levensverwachting verder toenemen (wat leidt tot een groeiende zorgvraag). De toename van complexere medische technologie in ziekenhuizen vereist wel dat niet alleen ziekenhuizen, zorginstellingen, instituten en fabrikanten, maar ook wetenschappers, artsen/ medische specialisten, fysici en technici van universiteiten, fabrikanten en zorginstellingen intensiever en structureler samenwerken. Te verwachten valt dat ICT competenties, alsook vaardigheden om samen te werken met andere instellingen en instituten en met collega's met een andere disciplinaire achtergrond en onderzoeksvaardigheden derhalve belangrijker zullen worden voor het werk van afgestudeerden. 



\section{Globalisering: toenemende behoefte aan internationale oriëntatie op de werkplek}

In hun beschouwing van de derde van de hier gepresenteerde trends geven Humburg en Van der Velden (2013) aan hoezeer deze trend is gestimuleerd door ICT-ontwikkelingen. Voor het eerst in de geschiedenis kan worden gesproken van een wereldeconomie met het vermogen om als een onderling verbonden eenheid gelijktijdig te fungeren op globale schaal (Castells, 200o). Dit heeft gevolgen voor handel, bedrijvigheid, informatiestromen en concurrentie tussen bedrijven. Hiermee heeft globalisering ook belangrijke consequenties voor de kennissamenleving, het invoeren van high-performance organisaties, evenals voor de flexibilisering van de relatie tussen werkgevers en werknemers.

Globalisering wordt gekenmerkt door de snelheid waarmee ideeën, kapitaal, goederen, diensten en mensen landsgrenzen passeren. Hierdoor is interactie met mensen van andere landen, culturen en taalachtergronden heel gewoon geworden. Ongeveer een derde van de Europese afgestudeerden werkt in een organisatie met een internationaal bereik, en een vergelijkbaar percentage heeft een hoog niveau van buitenlandse taalvaardigheden nodig om hun werk adequaat te kunnen uitoefenen (Pavlin and Svetlik, 20II). Ook de tendens naar plattere organisatievormen, evenals de mogelijkheden om via elektronische media zaken te doen, hebben belangrijke gevolgen voor het aantal individuen dat in cultureel heterogeen groepen werkt.

Globalisering wordt zoals gezegd voor een deel gevoed door de ICT-revolutie, maar heeft ook een eigen logica. Net als het effect van ICT veel verder reikt dan het feit dat men goed met de nieuwste technologieën overweg moet kunnen, wordt het effect van globalisering slechts ten dele weerspiegeld in de blootstelling van afgestudeerden aan klanten, collega's enz. uit andere landen. Minstens zo belangrijk is de toegenomen concurrentie, het feit dat bedrijven en consumenten niet meer alles op de lokale markt hoeven te kopen maar de hele wereld af kunnen struinen om de beste deals te krijgen. Arbeid kan van overal worden ingekocht en werk - inclusief in veel gevallen kenniswerk - kan overal worden uitbesteed. Deze indirecte effecten worden echter bij de behandeling van de andere trends besproken. We focussen hier op directe effecten van globalisering, hetgeen tot uitdrukking komt in het veel internationaler worden van studie en werk.

Los van de uitdagingen die de globalisering met zich meebrengt krijgt het hoger onderwijs in Nederland met de globalisering te maken, door de toegenomen stroom 
van buitenlandse studenten die een studie in Nederland volgen. Figuur 4.I geeft hiervan een beeld.

\section{Figuur 4.1}

Buitenlandse studenten in het bekostigde $\mathrm{HBO}$ en WO, als percentage van de respectievelijk totale studentenpopulaties, 2007-2012

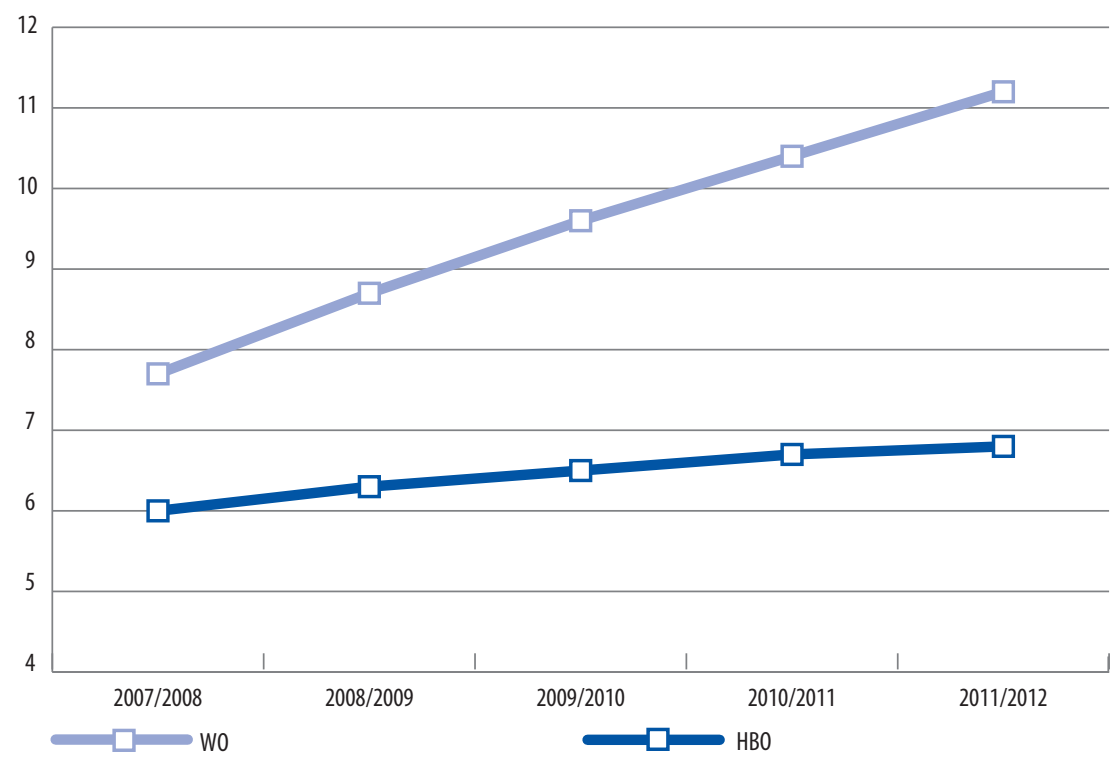

Bron: DUO/CFI, gepubliceerd door NUFFIC (2012)

Zoals figuur 4.I laat zien heeft vooralsnog de globalisering vooral voor het WO grote gevolgen gehad in term van de toename in de instroom van buitenlandse studenten. Het percentage stijgt ook voor het $\mathrm{HBO}$, maar heel langzaam.

Het in aanraking komen met medestudenten uit andere landen kan een goede voorbereiding vormen voor mogelijk latere werk in een internationale setting. Een andere manier voor studenten om internationale ervaring op te doen is om een stage of andere studieonderdeel in het buitenland te volgen. Figuur 4.2 laat dit zien. 


\section{Figuur 4.2}

Percentage afgestudeerden dat een stage en/of studieonderdeel in het buitenland heeft gevolgd tijdens de $\mathrm{HBO}$ opleiding

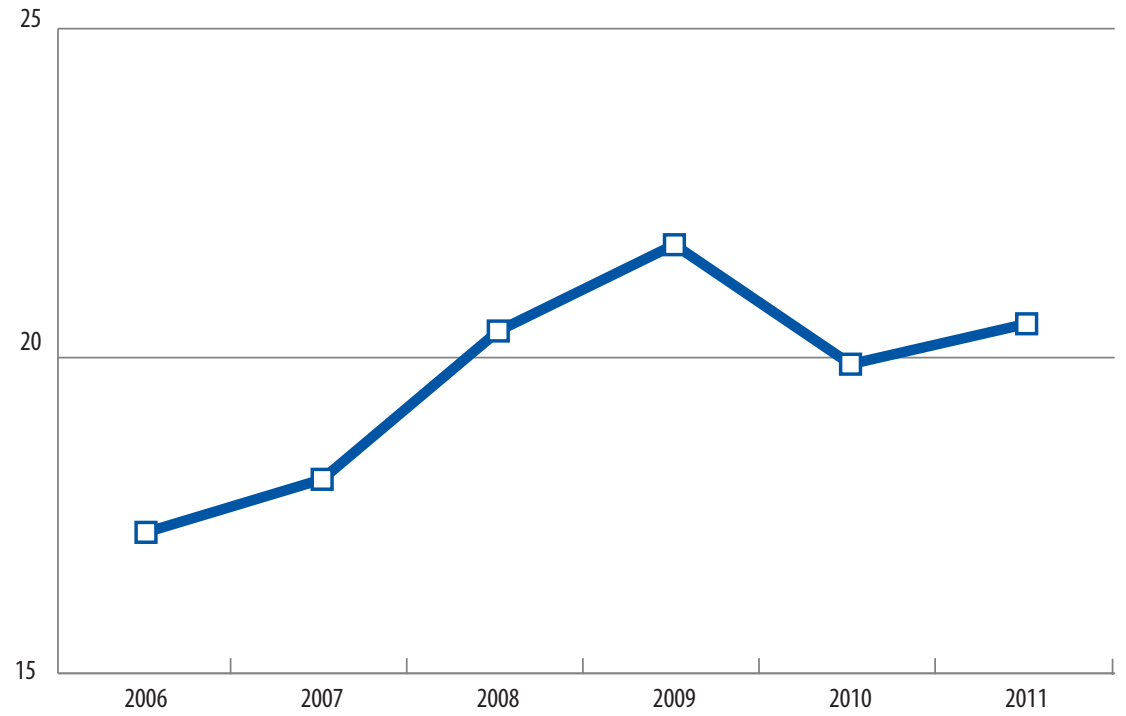

Bron: HBO-Monitor, 2006-2011

Zoals figuur 4.2 laat zien wordt door HBO'ers steeds vaker een deel van de studie in het buitenland doorgebracht. Het grootste deel hiervan bestaat uit buitenlandse stages. Zo'n I6\% van de afgestudeerden die in $201 \mathrm{I}$ werden benaderd gaf aan een buitenlandse stage te hebben gevolgd. Zo'n $8 \%$ gaf aan een studieonderdeel in het buitenland te hebben gevolgd.

Ondanks de toename in buitenlandervaring tijdens de studie lijkt geen sprake van dat meer Nederlandse HBO'ers na afronding van de studie ervoor kiest om in het buitenland te werken. Zoals figuur 4.3 laat zien daalt dit percentage zelfs de laatste jaren, na een korte opleving in het begin van het vorige decennium. ${ }^{2}$ Deze neerwaartse trend is opvallend gezien het feit dat het bevorderen van de mobiliteit één van de leidende principes van de Bolognaverklaring was. Ook lijkt de recente crisis niet als oorzaak van de daling te kunnen worden aangemerkt, gezien het feit dat de daling al enkele jaren voor het begin van de crisis is begonnen.

2. Het is natuurlijk moeilijk met zekerheid vast te stellen hoe accuraat dit percentage is, omdat we niet weten of het responspercentage bij afgestudeerden in het buitenland afwijkt van dat van afgestudeerden die in Nederland zijn gebleven. De absolute percentages dienen daarom met enige voorzichtigheid te worden benaderd. Er is echter geen reden om te denken dat een afwijkend responspatroon de richting van de trend bepaalt. 


\section{Figuur 4.3}

Percentage afgestudeerden dat op het moment van de enquête in het buitenland werkt (uitsluitend afgestudeerden die in Nederland zijn geboren).

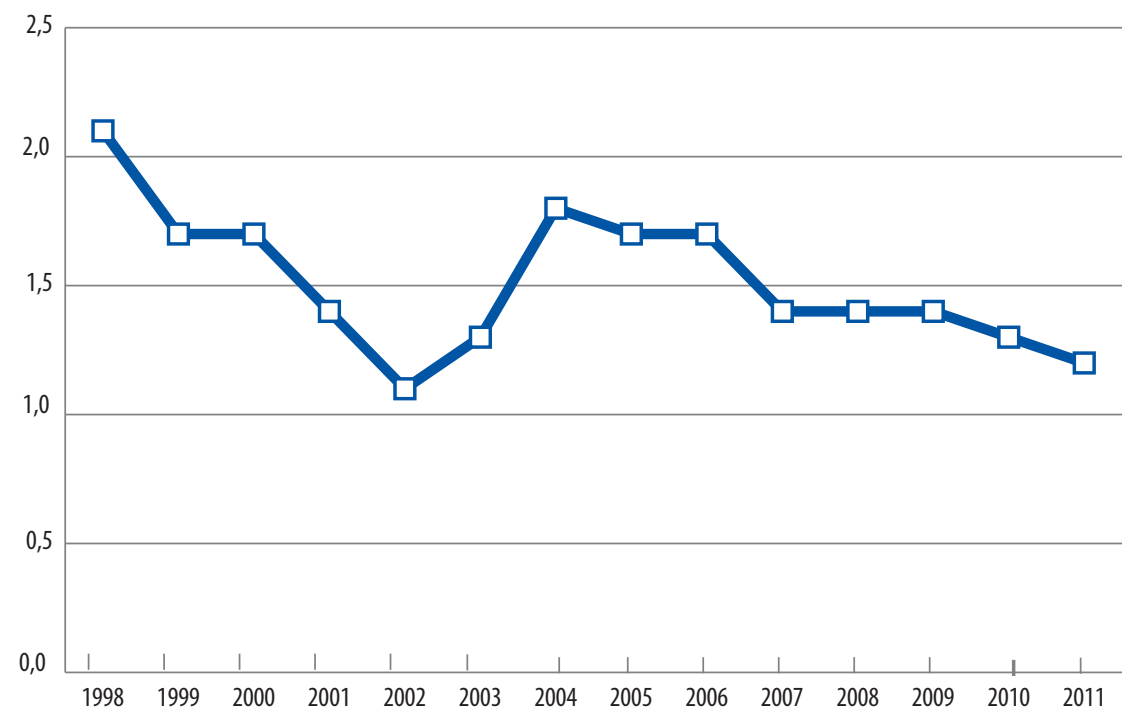

Bron: HBO-Monitor, 1998-2011

Cijfers van het al boven citeerde REFLEX onderzoek (Pavlin en Svetlik, 20II) bevestigen het beeld dat blijkt dat Nederlandse HBO'ers niet vaak naar het buitenland gaan na afronding van hun studie. Voor zo'n $1,7 \%$ van hen was de eerste baan in het buitenland, en slechts I\% werkt 5 jaar na afstuderen nog in het buitenland.

Enige relativering is hier natuurlijk op zijn plaats. Het $\mathrm{HBO}$ is vooral beroepsonderwijs, veelal bedoeld als specifieke voorbereiding op werk in een Nederlandse setting. Het feit dat HBO'ers niet vaak in het buitenland werken betekent niet dat ze niet internationaal georiënteerd zijn. Het percentage afgestudeerde HBO'ers dat 5 jaar na afstuderen in een organisatie werkt met een internationale reikwijdte komt sterk overeen met het boven geciteerde Europese gemiddelde: zo'n $33 \%$.

Hoe zit het met de competenties op het gebied van internationale orientatie? Hierbij kan natuurlijk worden gedacht aan kennis van buitenlandse talen. Maar behalve de taal kan het soms bijna net zo moeilijk zijn om de intenties, bedoelingen, gewoonten en dergelijke te begrijpen van mensen die zijn grootgebracht in een cultuur dat sterk verschilt van het Nederlandse cultuur. Dit kan gelden voor mensen met wie men zaken wil doen, maar ook voor bijvoorbeeld patiënten of leerlingen. Om deze reden plaatsen we de competentie "begrip tonen voor andere standpunten" bij internationale oriëntatie. Figuur 4.4 laat zien hoe het vereist niveau van deze competenties zich in de tijd heeft ontwikkeld, voor afgestudeerden werkzaam binnen hun kerndomein. 


\section{Figuur 4.4}

Trend in vereist niveau geselecteerde competenties (uitsluitend afgestudeerden werkzaam in kerndomein)

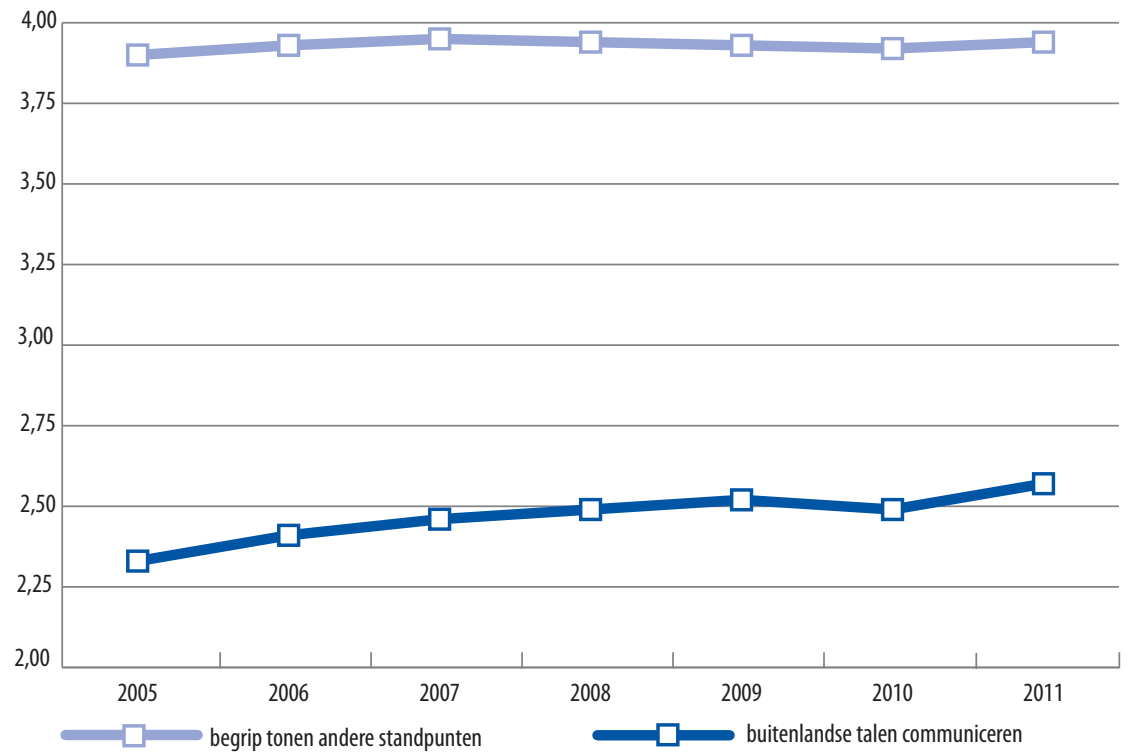

Bron: HBO-Monitor, 2005-2011

Een aantal dingen valt meteen op bij dit figuur. Ten eerste, het vereiste niveau van begrip voor andere standpunten ligt stabiel erg hoog. Ten tweede, het vereist niveau van buitenlandse talenkennis ligt veel lager. Ten derde, dit niveau is merkbaar gestegen in de afgelopen zes jaren. Het lage gemiddeld vereiste niveau van talenkennis is overigens weinig verrassend, omdat er zonder twijfel veel banen zullen zijn waar talenkennis in het geheel geen rol speelt. Wanneer we iets preciezer naar de cijfers kijken, blijkt dat er aan beide uiteinden van de schaal een verschuiving optreedt. Zo is het percentage "matig" (de laagste schaalwaarde) gezakt van $33 \%$ naar $25 \%$, terwijl het percentage "hoog/uitmuntend" (4 of 5 op de schaal) is gestegen van $19 \%$ naar $26 \%$. De implicatie hiervan is dat er steeds minder mensen aan het werk zijn in functies waar talenkennis niet of nauwelijks nodig is, terwijl steeds meer mensen in banen werken waar een sterke talenkennis vereist is.

Figuur 4.5 geeft een beeld van de ontwikkeling voor mensen met een baan op HBO niveau maar buiten de eigen richting. 


\section{Figuur 4.5}

Trend in vereist niveau geselecteerde competenties (uitsluitend afgestudeerden werkzaam op minimaal niveau maar buiten

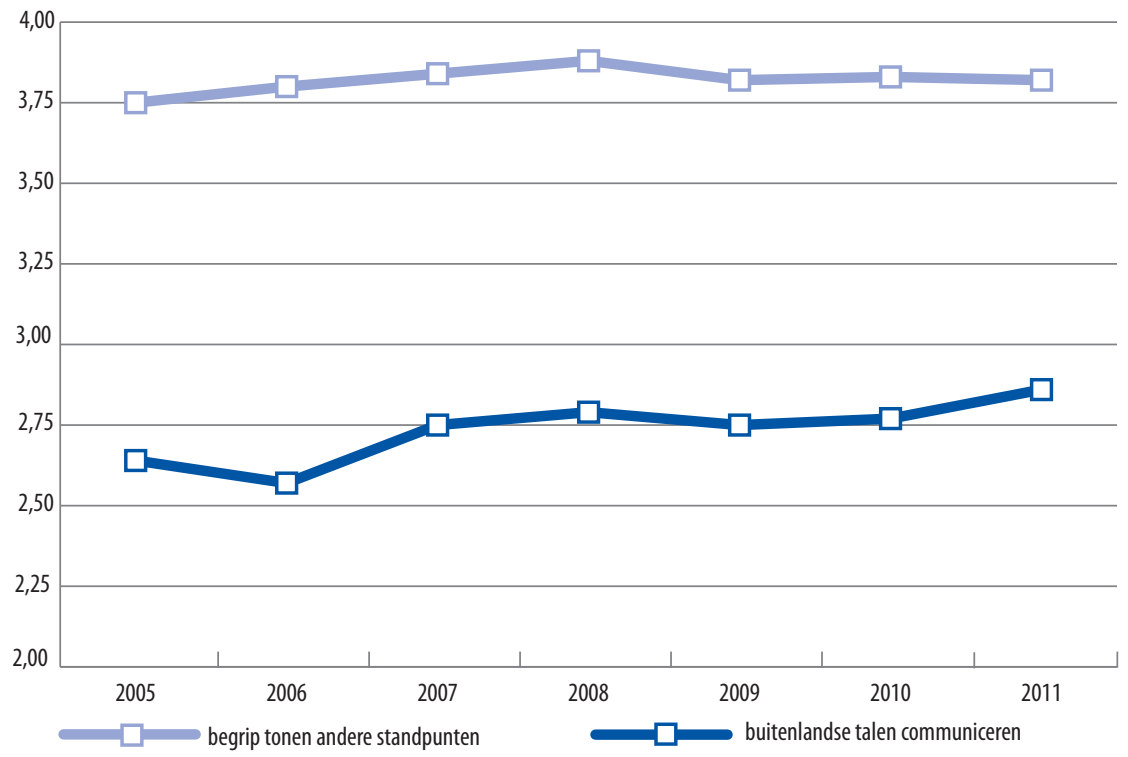

Bron: HBO-Monitor, 2005-2011

Het beeld lijkt sterk op dat voor werkenden in hun kerndomein. Het belangrijkste verschil is dat het niveau van talenkennis structureel hoger ligt voor deze groep. Dit heeft waarschijnlijk te maken met het feit dat werkgevers bij banen waarvoor een hoog niveau aan talenkennis nodig is uit een brede opleidingsvijver vissen.

Uit figuur 4.6 blijkt dat de tekorten aan talenkennis enigszins toenemen onder invloed van de stijging in het vereiste niveau. Vooralsnog is het percentage met een tekort op deze competentie vrij laag. Desalniettemin lijkt het verstandig om de ontwikkeling hiervan in de gaten houden op het niveau van afzonderlijke opleidingen en hogescholen. Het lage percentage tekorten in het algemeen kan immers "lokale" problemen maskeren. 


\section{Figuur 4.6}

Trend in tekorten van geselecteerde competenties (uitsluitend afgestudeerden werkzaam in kerndomein)

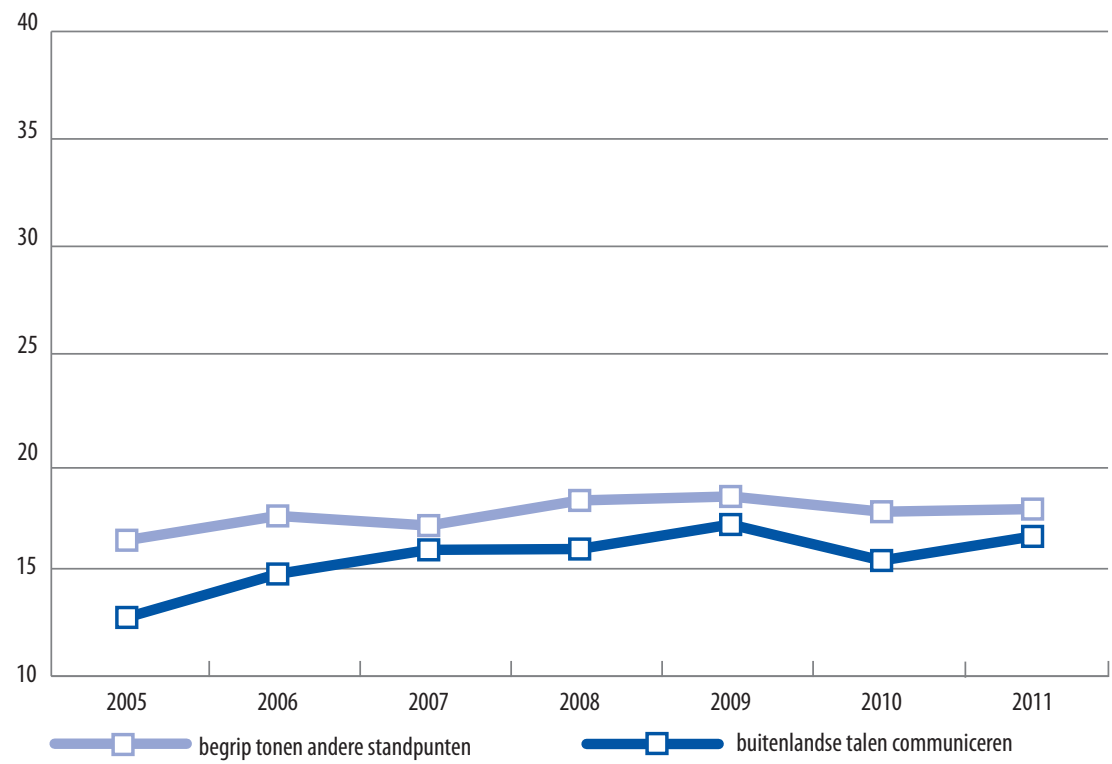

Bron: HBO-Monitor, 2005-2011

In hoeverre wordt het vereist niveau van deze competenties beinvloedt door het werken in het buitenland? Figuur 4.7 geeft hiervan een beeld.

\section{Figuur 4.7}

Trend in vereist niveau geselecteerde competenties, naar land huidige baan (uitsluitend afgestudeerden werkzaam in kerndomein)
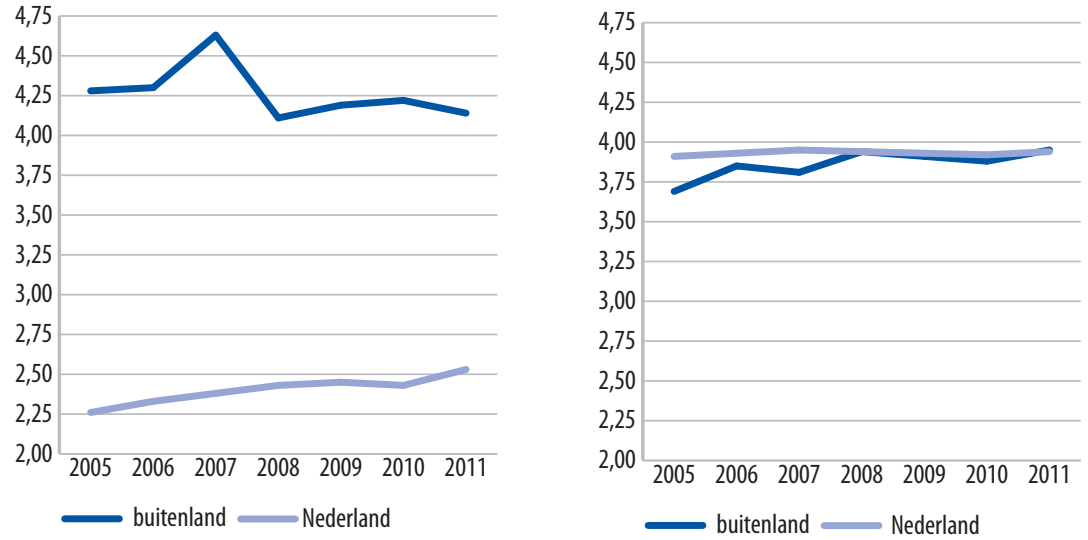

Bron: HBO-Monitor, 2005-2011 
Zoals zou worden verwacht hangt het vereist niveau van taalvaardigheden sterk samen met het land waarin men na de opleiding werkt. Opvallend is echter dat het verschil kleiner wordt in de tijd. De verandering komt van beide kanten. Dit ligt vooral aan het feit dat mensen die in Nederland werken, over een steeds hoger niveau aan taalvaardigheden dienen te beschikken. Dit bevestigt nog eens het beeld dat ook in Nederland het werk steeds internationaler wordt. Het lijkt ook alsof het vereist niveau van taalvaardigheden in de tijd iets lager wordt voor mensen die in het buitenland werken. Deze verandering is echter klein, en misschien op toeval gebaseerd. Wat in ieder geval zeker lijkt is dat het belang van deze competentie de laatste jaren niet is toegenomen onder mensen die in het buitenland werken, hetgeen niet verwonderlijk is gegeven het hoog gemiddeld niveau.

Het vereist niveau van begrip voor andere standpunten ligt structureel behoorlijk hoog ongeacht het land waarin men werkt. Opvallend is wel dat dit niveau halverwege het vorige decennium juist hoger lag onder mensen die in Nederland werken, maar dat door een stijging in het gemiddeld vereiste niveau onder mensen die in het buitenland werken dit verschil anno $201 \mathrm{I}$ in het geheel is verdwenen. 


\section{De veranderende economische structuur: het belang van ondernemerschapscompetenties}

Deze trend heeft veel te maken met de al genoemde trends. Humburg en Van der Velden (2013) merken op dat de omgeving waarin bedrijven en organisaties opereren sterk veranderd is onder invloed van technologische veranderingen en globalisering, maar ook door de toegenomen welvaart en de deregulering van markten. Dit heeft geleid tot veel aandacht voor zaken als zelfstandig ondernemerschap, plattere organisatievormen, de rol van kleinere bedrijven in de economie, gespecialiseerde en deels zelfstandige eenheden binnen grotere bedrijven, flexibelere werkomgevingen, en zo voorts. Door veranderingen op deze fronten wordt beoogt om meer maatwerk te kunnen leveren aan klanten en sneller te kunnen reageren op de behoeften van de markt.

\section{Figuur 5.1}

Trend in percentage zelfstandigen/freelancers, naar niveau en richting van de baan

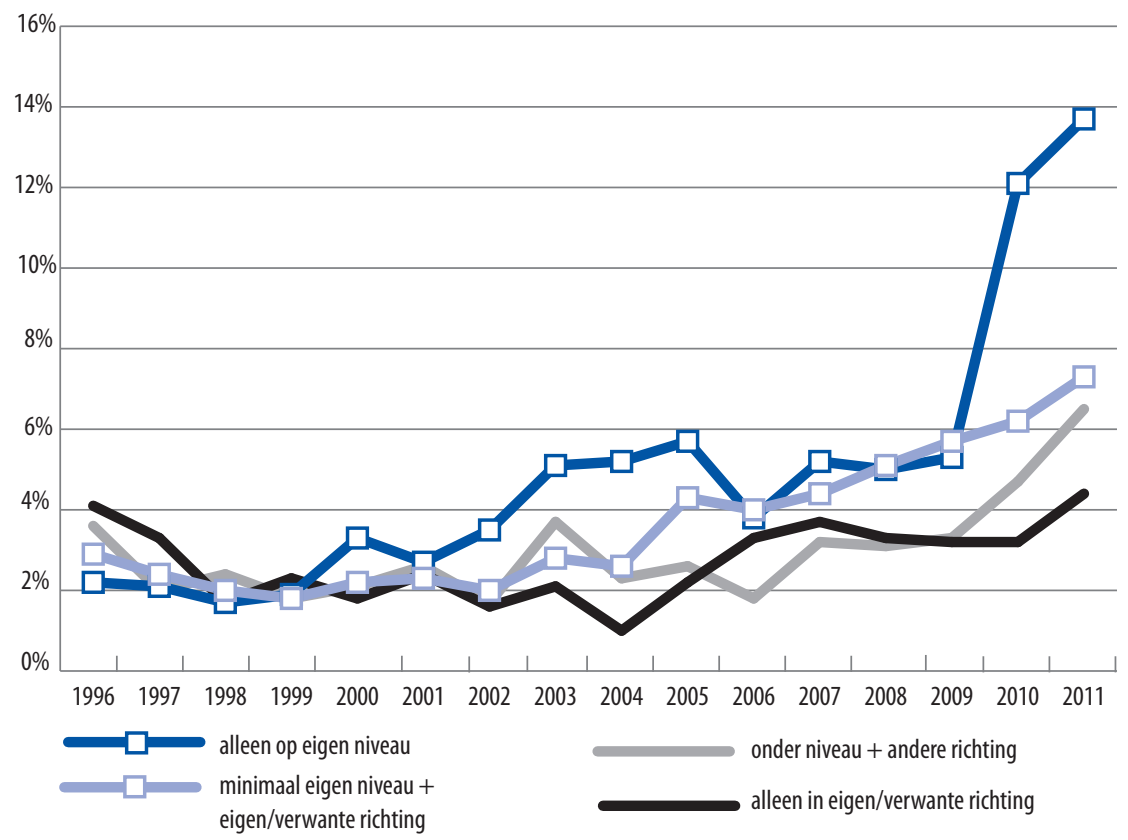

Bron: HBO-Monitor, 1996-2011 
De gemeenschappelijke noemer bij deze zaken is het toegenomen belang van ondernemerschapscompetenties. Kenniswerkers worden geacht alert te zijn op veranderingen in markten, en nieuwe innovaties snel op te kunnen pikken en te introduceren in de eigen organisatie. Een sterkere set ondernemerschapscompetenties, bestaande uit zaken zoals het vermogen om problemen en kansen te kunnen signaleren en het goed kunnen presteren onder druk, kunnen van groot belang zijn, zowel voor mensen die voor zichzelf een eigen bedrijf willen opzetten, als voor mensen die een eigen niche als employé binnen een grotere bedrijf willen creëren.

Figuur 5.I geeft het percentage afgestudeerden weer dat als zelfstandige of freelancer werkt.

\section{Figuur 5.2}

Trend in percentage werkzaam bij kleine en middelgrote organisaties

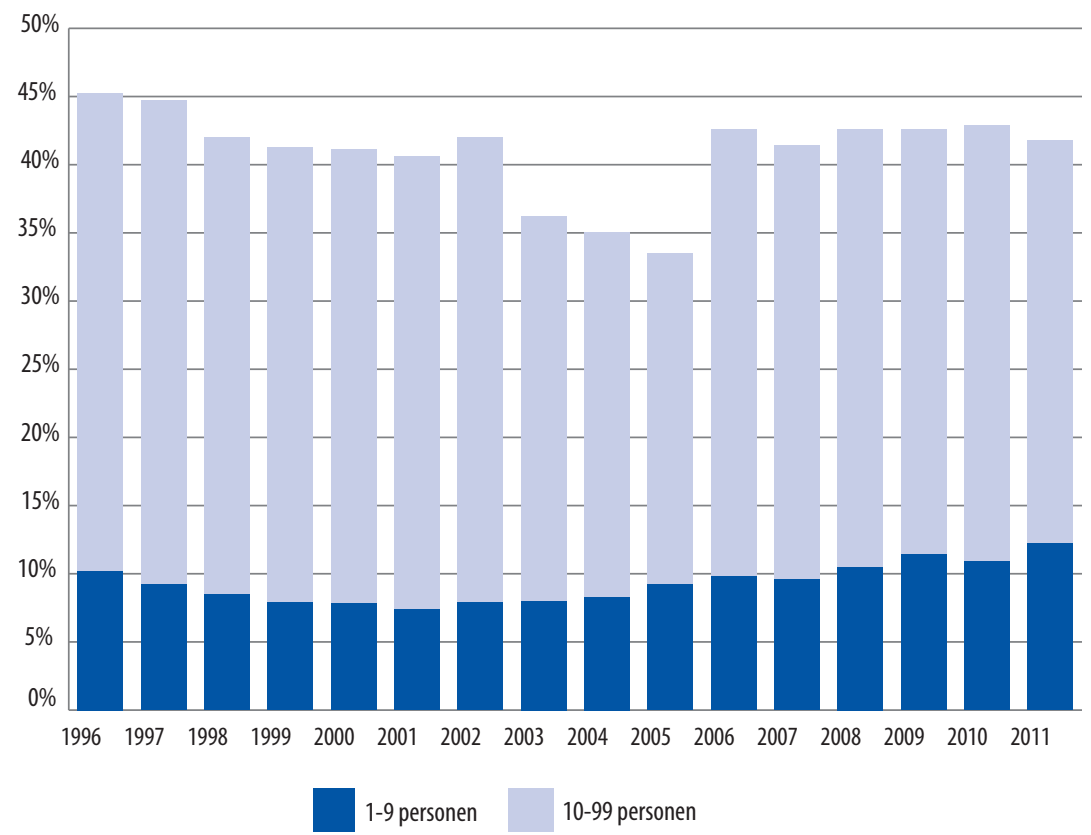

Bron: HBO-Monitor, 1996-2011

$\mathrm{Na}$ jarenlang op een laag niveau te hebben gezeten is het percentage afgestudeerden dat voor zichzelf werkt de laatste vijf jaren fors gestegen. Opvallend is dat dit vooral geldt vooral voor mensen die op eigen niveau werkzaam zijn buiten hun eigen richting. De scherpe stijging van het percentage zelfstandigen/freelancers in de laatste twee jaren wordt deels bepaald door extreme percentages voor de sector KUO: 69\% en $74 \%$ van de afgestudeerden van deze sector die op niveau een niet aan de opleiding gerelateerde baan bekleedde werkte voor zichtzelf . Maar de stijging is ook bij de meeste andere sectoren ook zichtbaar. Dit zal ongetwijfeld voor een deel te wijten zijn 
aan de economische crisis: om aan het werk te blijven gaan sommige mensen noodgedwongen voor zichzelf beginnen, desnoods op een werkterrein dat niet aansluit bij hun opleiding. Het is echter ook opvallend dat de stijging in het percentage zelfstandigen/freelancers al ruim vóór de crisis in 2008 uitbrak is begonnen. Vooral bij werkenden binnen hun eigen kerndomein is dit heel duidelijk. Dit lijkt erop te wijzen dat er een reële verandering in het denken is opgetreden, en dat een eigen bedrijf bij steeds meer afgestudeerden een realiteit is geworden.

Een andere belangrijke indicator als het om ondernemerschap gaat is het percentage werkzaam in kleinere organisaties. Figuur 5.2 laat dit zien.

Vanaf 2003 is het percentage afgestudeerden dat werkt in een kleine organisatie (9 personen of minder) duidelijk toe. Een nadere analyse leert dat deze toename in het geheel toe te schrijven is aan het aandeel dat als zelfstandige/freelancer werkt. We zagen al in figuur 5.I dat dit aandeel aan het stijgen is. Zoals figuur 5.3 laat zien, is het aandeel mensen die in een kleine organisatie werkt vele malen hoger ligt bij freelancers en zelfstandigen dan bij mensen in loondienst of met een andersoortig dienstverband. Bovendien stijgt dit aandeel bij deze groep in de tijd, van minder dan $70 \%$ in 1996 tot ruim $80 \%$ in 201 .

\section{Figuur 5.3}

Trend in percentage werkzaam bij kleine organisaties (1-9 personen), naar type dienstverband
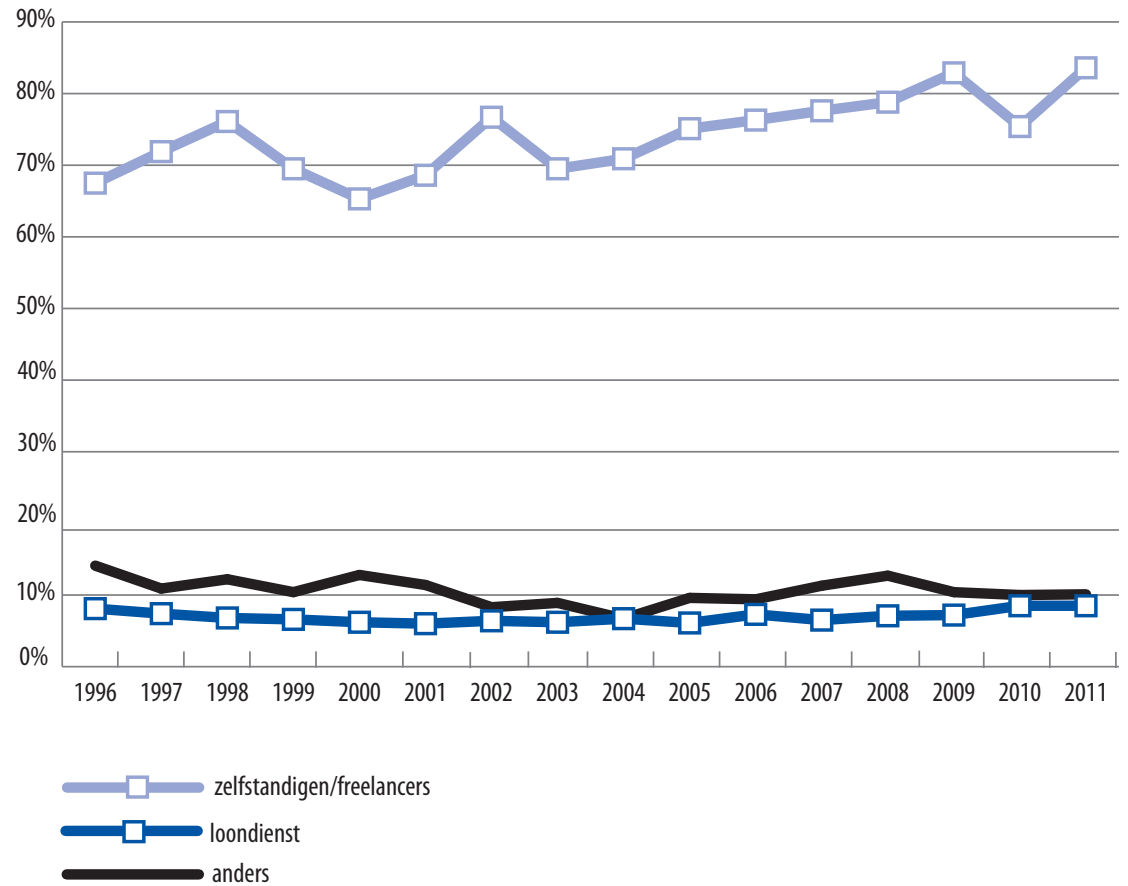

Bron: HBO-Monitor, 1996-2011 
Hoe zit het met de ondernemerschapscompetenties van Nederlandse HBO'ers? Uit het REFLEX-onderzoek blijkt dat slechts I6\% van de HBO'ers hun opleiding een goede voorbereiding vond op het gebied van het ontwikkelen van ondernemerschapsvaardigheden. Betekent dat soms dat deze competenties onbelangrijk zijn? Figuur 5.4 geeft de trend in het vereist niveau van een aantal competenties die belangrijk kunnen zijn voor ondernemerschap, voor afgestudeerden werkzaam binnen hun kerndomein.

\section{Figuur 5.4}

Trend in vereist niveau geselecteerde competenties (uitsluitend afgestudeerden werkzaam in kerndomein)

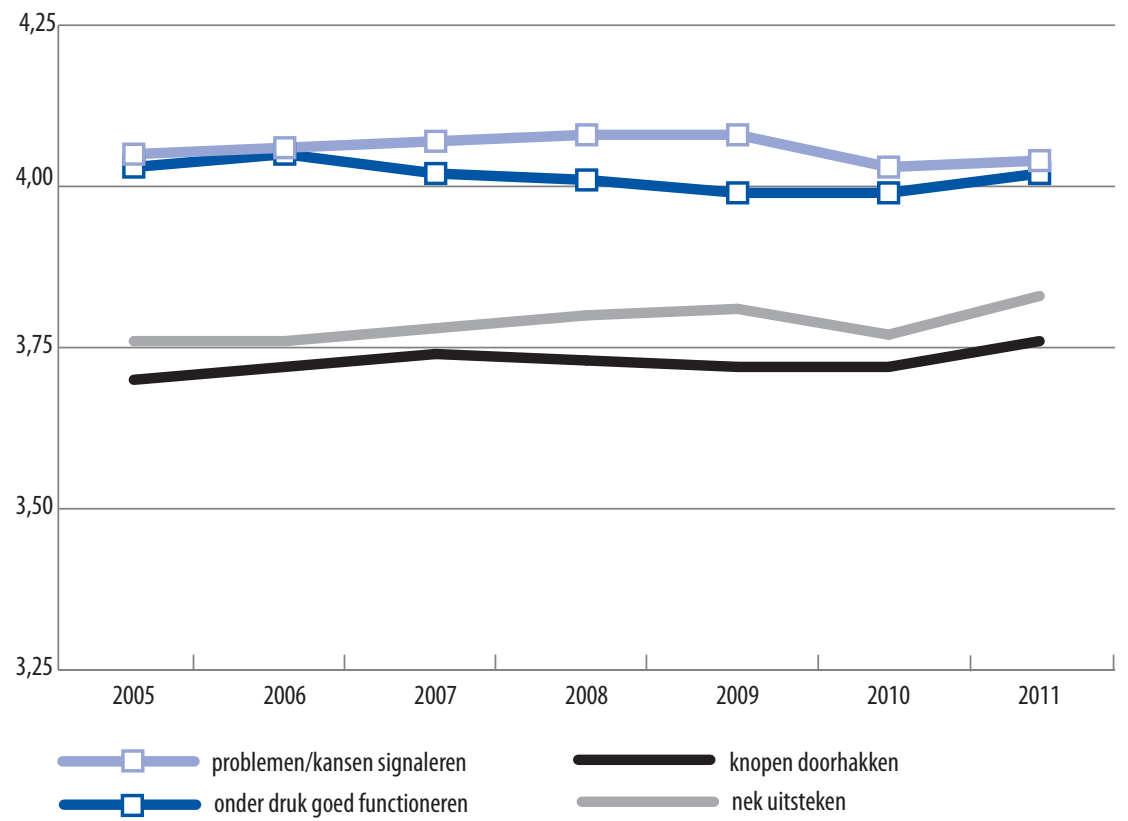

Bron: HBO-Monitor, 2005-2011

Hoewel er verschillen zijn in het gemiddeld niveau waarop deze competenties worden vereist, lijkt er geen sprake van te zijn dat deze competenties onbelangrijk worden gevonden. Het vermogen om problemen en kansen te signaleren en het vermogen om onder druk goed te kunnen functioneren worden structureel op hoog niveau vereist. Het niveau van de andere twee competenties ligt wat lager, maar lijkt enigszins te stijgen in de tijd. Zoals uit figuur 5.5 blijkt, maakt het voor het vereist niveau van ondernemerschapscompetenties weinig uit of men buiten de eigen richting werkt, zolang als het nog om een $\mathrm{HBO}$ functie gaat. Dit suggereert dat ondernemerschap een sterk generieke kenmerk is. 


\section{Figuur 5.5}

Trend in vereist niveau geselecteerde competenties (uitsluitend afgestudeerden werkzaam op minimaal niveau maar buiten de eigen opleidingsrichting)

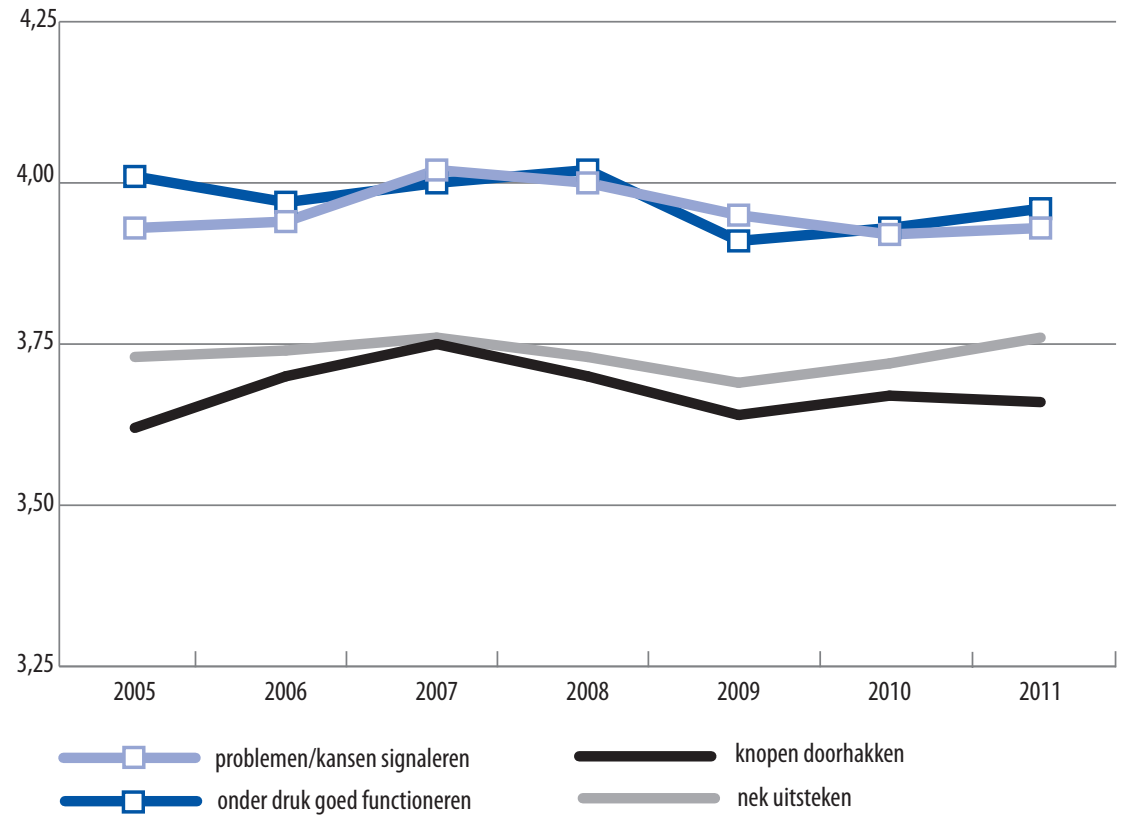

Bron: HBO-Monitor, 2005-2011

Wellicht de belangrijkste vraag is in hoeverre het $\mathrm{HBO}$ men op deze vereisten voorbereid. Figuur 5.6 laat het percentage afgestudeerden werkzaam binnen het kerndomein zien met een tekort op deze competenties. 


\section{Figuur 5.6}

Trend in tekorten van geselecteerde competenties (uitsluitend afgestudeerden werkzaam in kerndomein)

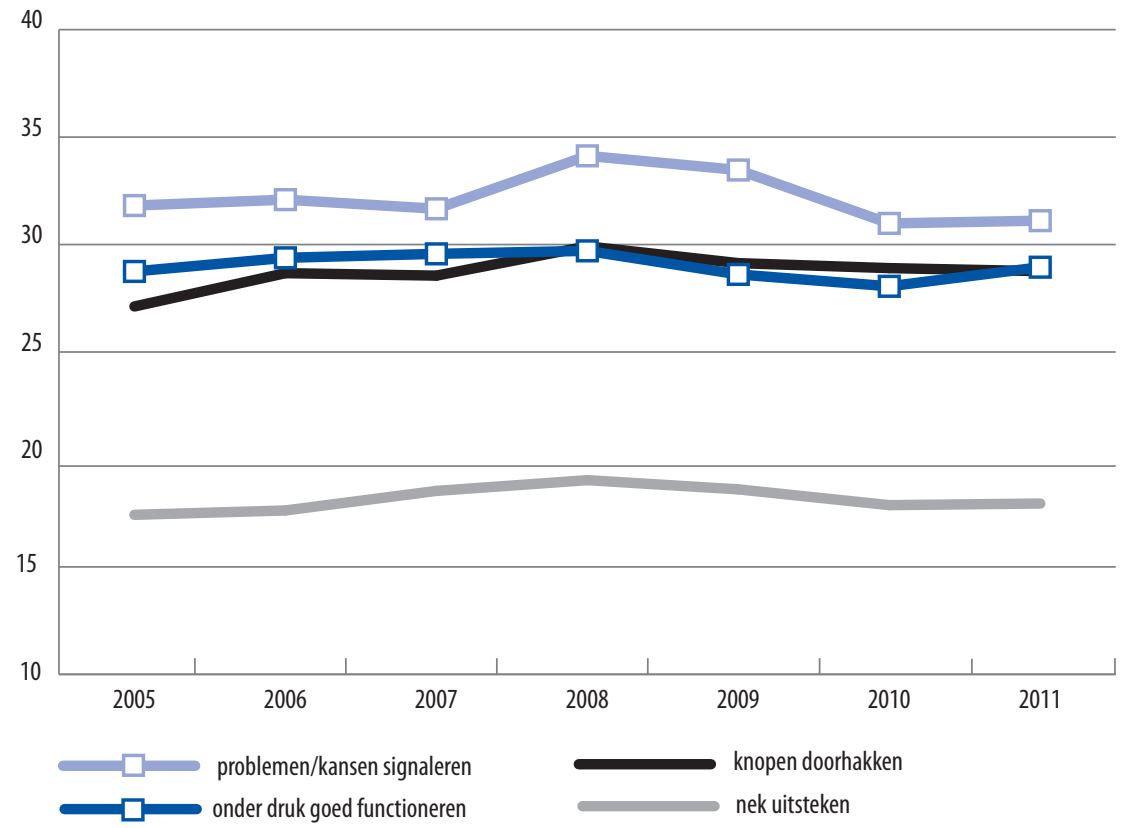

Bron: HBO-Monitor, 2005-2011

Op de bereidheid om de eigen nek uit te steken na kampt ruim een kwart van de afgestudeerden met een tekort op deze competenties. In het geval van het vermogen om problemen en kansen te signaleren gaat het zelfs om bijna één op de drie. Er lijkt geen noemenswaardige verandering in de tijd te zijn in het aandeel afgestudeerden met een tekort aan deze competenties. Het is interessant om na te gaan of het vereist niveau van ondernemerschapscompetenties zich anders ontwikkelt voor mensen in kleinere versus grotere organisaties, of voor zelfstandigen en freelancers vergeleken met mensen in loondienst. Dit wordt weergegeven in figuren 5.7 en 5.8, aan de hand van een gemiddeld vereist niveau van de vier competenties. 


\section{Figuur 5.7}

Trend in vereiste ondernemerschapscompetenties naar bedrijfsgrootte (uitsluitend afgestudeerden werkzaam in kerndomein)

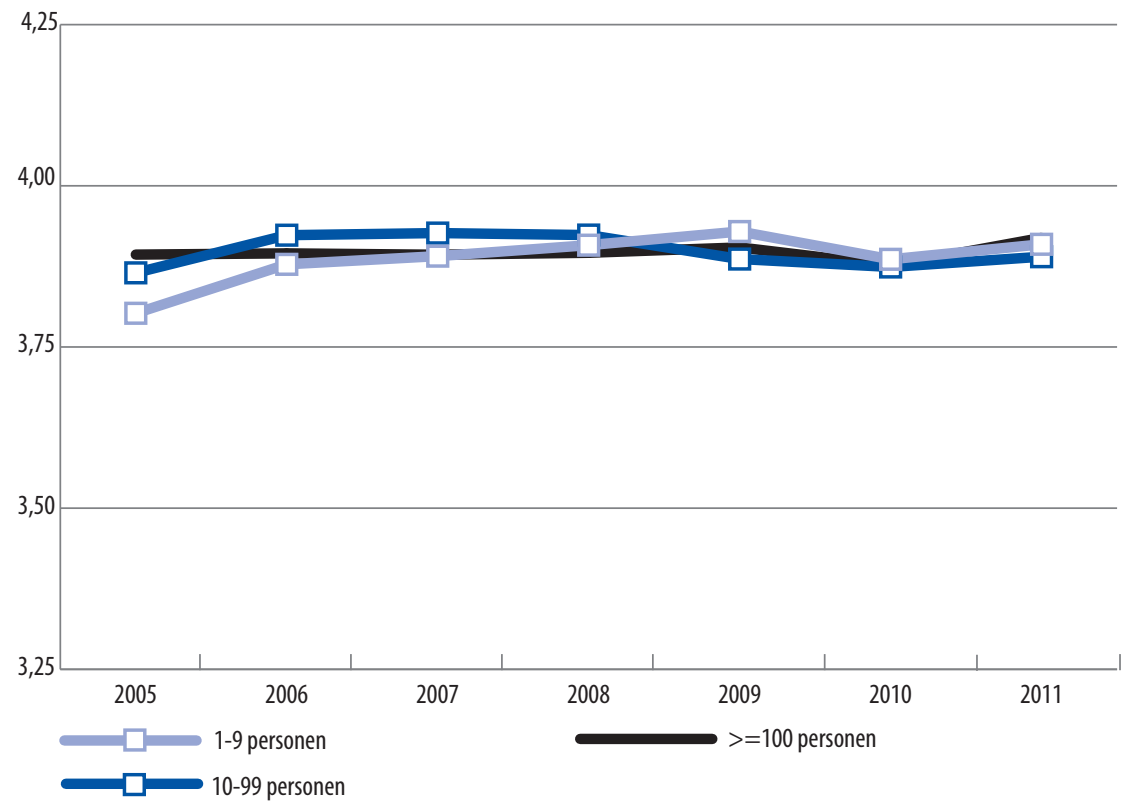

Bron: HBO-Monitor, 2005-2011

Het vereist niveau lijkt van deze competenties vooral te stijgen onder mensen die in kleine bedrijven werken. Er lijkt ook een trend naar het belangrijker worden van deze competenties voor zelfstandigen en freelancers, al kan dit deels, of misschien in het geheel, een conjunctureel effect blijken te zijn. Het ligt immers voor de hand dat de ondernemerschapsvaardigheden van mensen die voor zichzelf werken het zwaarst op de proef worden gesteld in moeilijker tijden. Interessant is de bevinding dat het vereist niveau een structurele stijging toont bij de categorie "ander dienstverband". Dit zijn voornamelijk uitzendwerkers, een groep die in het verleden een relatief laag niveau van deze competenties nodig heeft gehad. Het lijkt erop dat ook de uitzendwereld competitiever aan het worden is. 


\section{Figuur 5.8}

Trend in vereiste ondernemerschapscompetenties naar dienstverbandbedrijfsgrootte (uitsluitend afgestudeerden werkzaam in kerndomein)

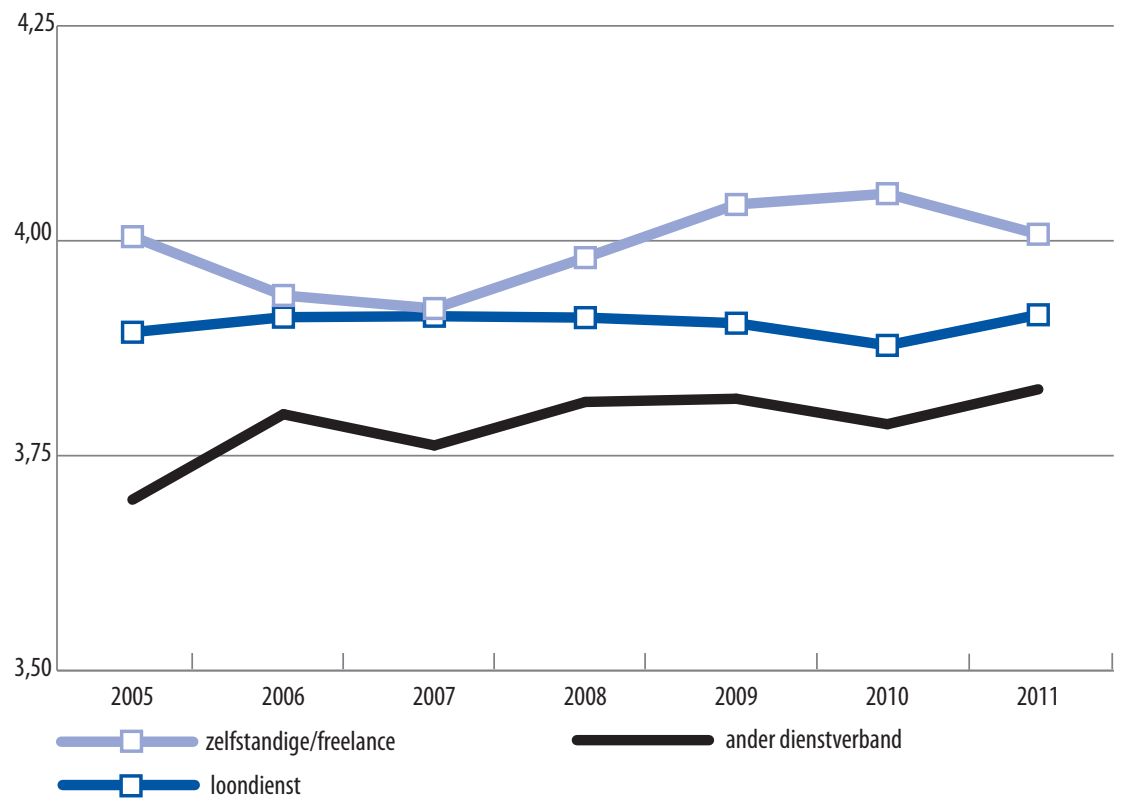

Bron: HBO-Monitor, 2005-2011 


\section{High-performance organisaties: mobilisatie van het beschikbare menselijk kapitaal}

Sterk verwant aan het begrip van ondernemerschap, en ook aan innovatie en kennismanagement, is de trend naar het ombouwen van (onderdelen van) bedrijven en organisaties in zogenoemde : high-performance workplaces". Humburg en Van der Velden (20I3) geven aan hoe het geloof in traditionele bureaucratische organisatievormen is afgenomen in recente decennia. De perceptie is dat zulke managementstijlen een remmende werking hebben op innovatie, en resulteren in een zware onderbenutting van de capaciteiten van kenniswerkers.

Organisaties die sterk afhankelijk zijn van de prestaties van kenniswerkers en hun organisatievorm aanpassen om hier beter gebruik van te kunnen maken, worden door de OECD (1999) "high performance organizations" genoemd. Deze onderscheiden zich van andere organisaties door de brede variëteit aan vaardigheden die worden ingezet, het uitgebreid gebruik van deels zelfstandige teams, met een bijbehorende reductie in het aantal hiërarchische niveaus (Betcherman, 1997). Dit zou kenniswerkers beter in staat stellen om strategische besluiten af te stemmen op de nieuwste innovaties, en de snelheid van besluitvorming in organisaties vergroten. Werknemers worden hierdoor veel directer betrokken in de brede productieprocessen van hun organisaties, en zouden dan beter in staat zijn om organisatiedoelen en prioriteiten te begrijpen (Bills, 2004). Er zijn veel onderzoeken waaruit de effectiviteit van zulke praktijken zou blijken (zie bijvoorbeeld Appelbaum et al. 2000; Bartel 2004; Black en Lynch 2004).

Deze trend wordt sterk gestimuleerd door technologische veranderingen, en onderzoek heeft het verband met investeringen in ICT aangetoond (Arnal, Ok en Torres, 200I). Bijvoorbeeld, gecentraliseerde databases stellen autonome teams in staat om hele processen te overzien die vroeger door fragmentatie onmogelijk zouden zijn geweest. ICT maakt het ook veel gemakkelijker om werknemers met complementaire expertise bij elkaar te brengen en te laten samenwerken.

Door invoering van zulke high-performance organisaties wordt het belang van interpersoonlijke vaardigheden naar de voorgrond geduwd. Het belang van dergelijke vaardigheden is echter allerminst iets nieuws (Dede, 20IO). Het is echter duidelijk dat de eisen die aan leden van autonome teams worden gesteld heel anders zijn dan de eisen die aan werknemers in hiërarchische organisaties werken worden gesteld. Interpersoonlijke skills waren traditioneel vooral het domein van managers, nu wordt 
elk lid van een team geacht goed te kunnen communiceren en samenwerken. Dit heeft onder andere te maken met het sterk interdisciplinair karakter van veel teams (Karoly, 2004), waardoor heldere communicatie, (zelf-)evaluatie, het vermogen om andere aan te sturen, en het gericht zoeken naar advies en ondersteuning onmisbaar worden.

Dat veel afgestudeerden direct betrokken zijn bij het strategisch beleid van de organisatie waarvoor ze werken blijkt uit het REFLEX onderzoek: ongeveer 5 jaren na afgestuderen bleek ongeveer een kwart van HBO'ers een rol te spelen bij het stellen van doelen of het beslissen van strategieën voor hun organisatie.

Wellicht een weerspiegeling van de trend naar nieuwe organisatievormen is de dalende trend in het percentage HBO'ers dat leiding geeft. Dit staat in figuur 6.I.

\section{Figuur 6.1}

Trend in percentage leidinggevenden, naar niveau en richting van de baan

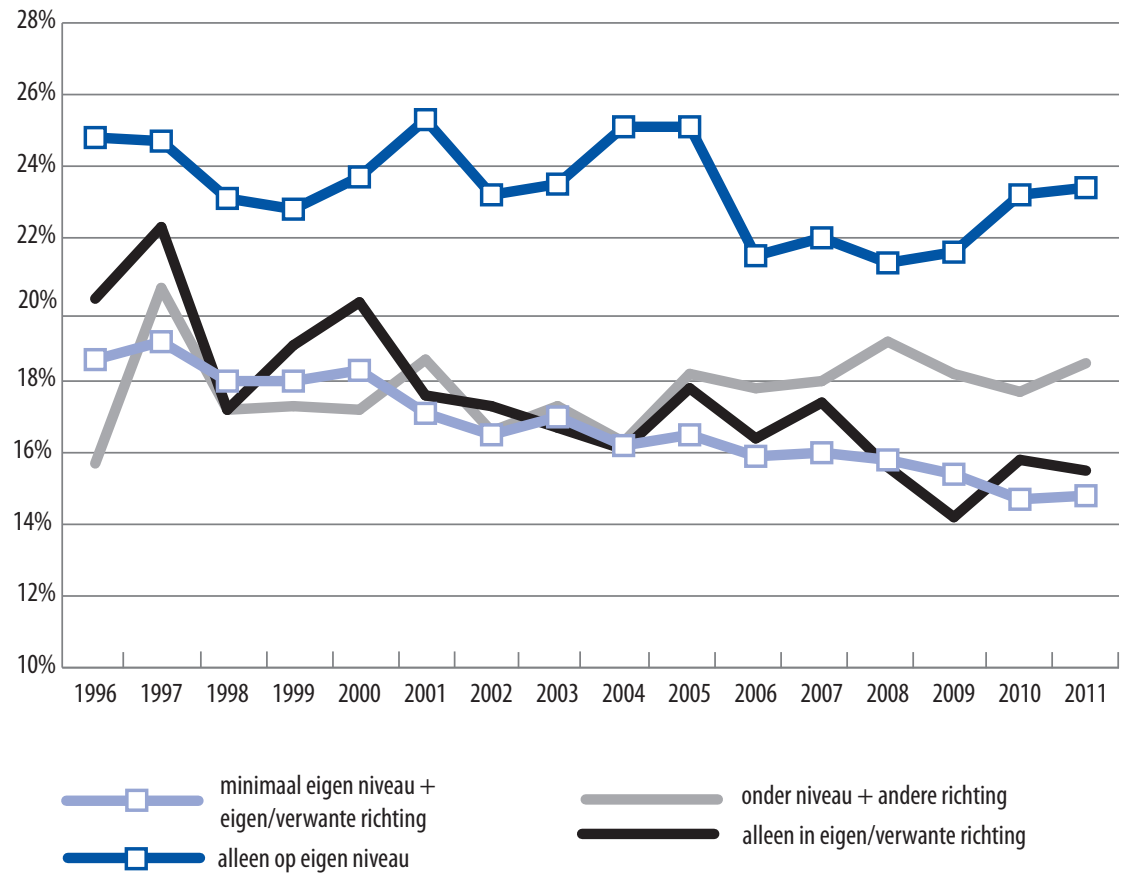

Bron: HBO-Monitor, 1996-2011

Wellicht het meest interessant aan deze grafiek is het feit dat het hoogste percentage leidinggevenden te zien is onder afgestudeerden die op HBO-niveau werkzaam zijn, maar buiten de eigen richting. Dit percentage is echter in de tijd aan het afnemen. Dit geldt nog sterker voor afgestudeerden die in hun kerndomein werkzaam zijn, 
en ook voor mensen die binnen de eigen richting maar onder $\mathrm{HBO}$-niveau werken. Alleen voor afgestudeerden die zowel naar niveau als naar richting buiten hun kerndomein werken geldt dat er geen structurele trend te zien is.

Een tweetal vragen uit het REFLEX-enquête kunnen wellicht enig licht werpen op de mate van onderlinge afhankelijkheid tussen werknemers in bedrijven en organisaties. De oud-studenten zijn gevraagd om aan te geven in welke mate de resultaten van hun werk afhankelijk zijn van de prestaties van anderen, en in welke mate de resultaten van het werk van anderen afhankelijk zijn van de eigen prestaties van de oud studenten zelf. Figuur 6.2 geeft per bedrijfstak het percentage oud-studenten van het Nederlandse HBO weer waarvoor deze uitspraken in sterke mate golden.

\section{Figuur 6.2}

Mate van onderlinge afhankelijkheid tussen werknemers, per bedrijfstak

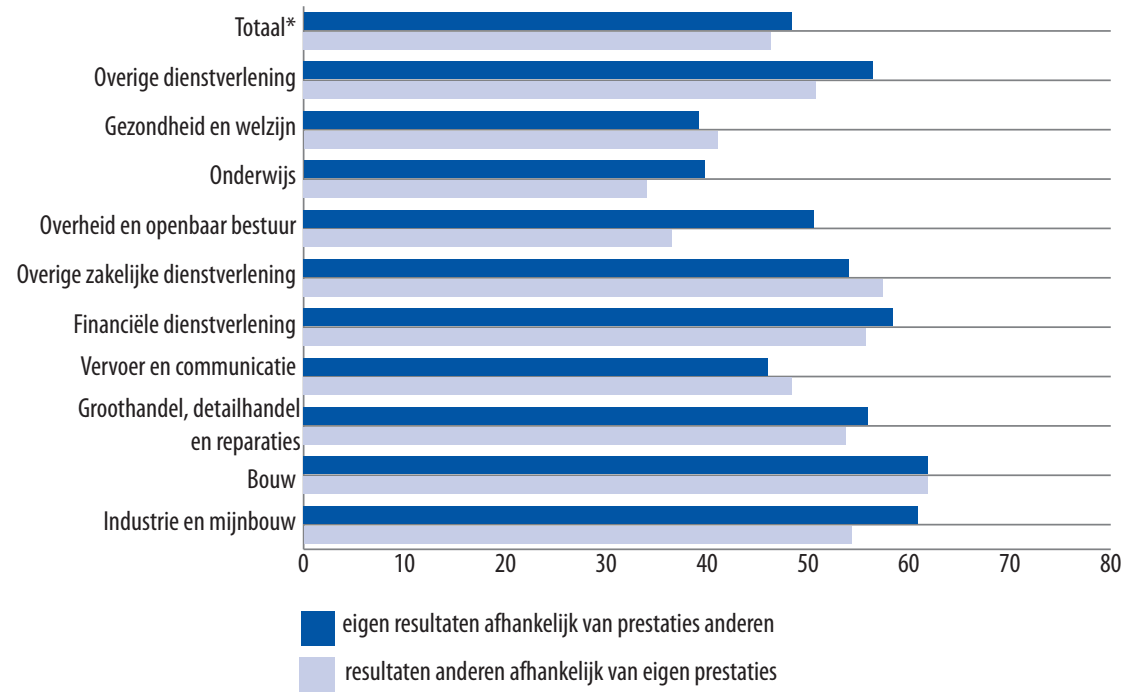

Bron: REFLEX-project

* Inclusief Landbouw \& visserij, Nutsbedrijven en Horeca (niet apart vermeld vanwege te kleine aantallen)

Over de hele linie blijkt het werk van bijna de helft van de oud-studenten gekenmerkt te zijn door een hoge mate van onderlinge afhankelijkheid. De afhankelijkheid lijkt het sterkst te zijn in de financiële dienstverlening, de industrie en mijnbouw, en in de bouw, en het minst sterk in het onderwijs, de gezondheid- en welzijnssector, en bij de overheid en het openbaar bestuur. Vooral bij die laatste sector is spraken van een veel sterkere afhankelijkheid van de eigen resultaten van de prestaties van anderen.

Hoe zit het met de inter- en intrapersoonlijke competenties van afgestudeerden? Figuur 6.3 geeft hiervan een beeld, voor mensen die binnen hun kerndomein werken. 
Figuur 6.3

Trend in vereist niveau geselecteerde competenties (uitsluitend afgestudeerden werkzaam in kerndomein)

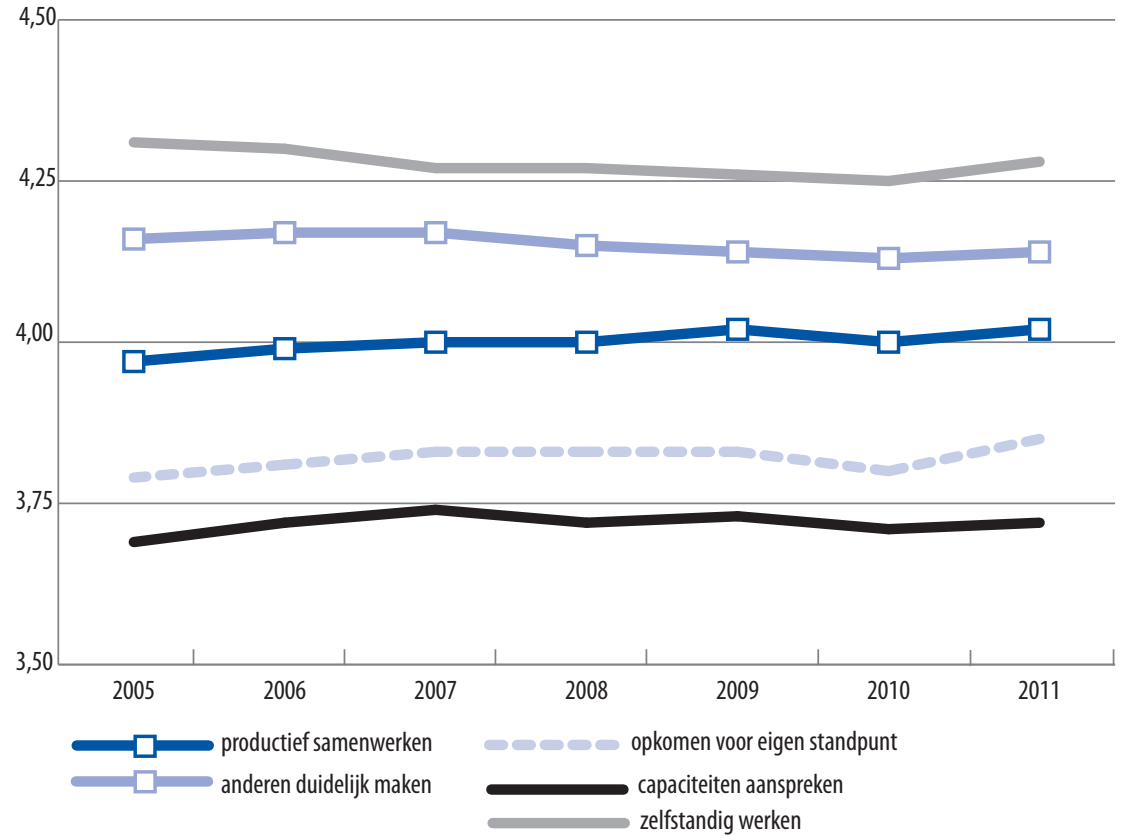

Bron: HBO-Monitor, 2005-2011

Zoals wellicht zou worden verwacht gezien het relatief laag percentage afgestudeerden dat leiding geeft, ligt het vereist niveau van het vermogen om capaciteiten van anderen aan te spreken het laagst van de inter- en intrapersoonlijke (die wij in het vervolg voor het gemak mobilisatiecompetenties noemen, omdat ze nodig zijn om menselijk hulpbronnen in organisaties te mobiliseren). Opvallend is echter dat dit gemiddeld niveau niet daalt, ondanks het feit dat het percentage leidinggevenden voor deze groep in dezelfde periode daalde van $16,5 \%$ naar $14,8 \%$. We komen straks hierop terug. Ook blijft het vereist niveau van de overige mobilisatiecompetenties stabiel in de tijd, zij het op een hoger gemiddeld niveau. Voor afgestudeerden die buiten hun richting werken maar op HBO-niveau is het beeld nauwelijks anders, behalve dat het absolute niveau waarop alle competenties worden vereist een fractie lager ligt. Om deze reden wordt deze grafiek hier achterwege gelaten.

Veel belangrijker is uiteraard hoe het zit met de tekorten. Dit staat afgebeeld in figuur 6.4 . 


\section{Figuur 6.4}

Trend in tekorten van geselecteerde competenties (uitsluitend afgestudeerden werkzaam in kerndomein)

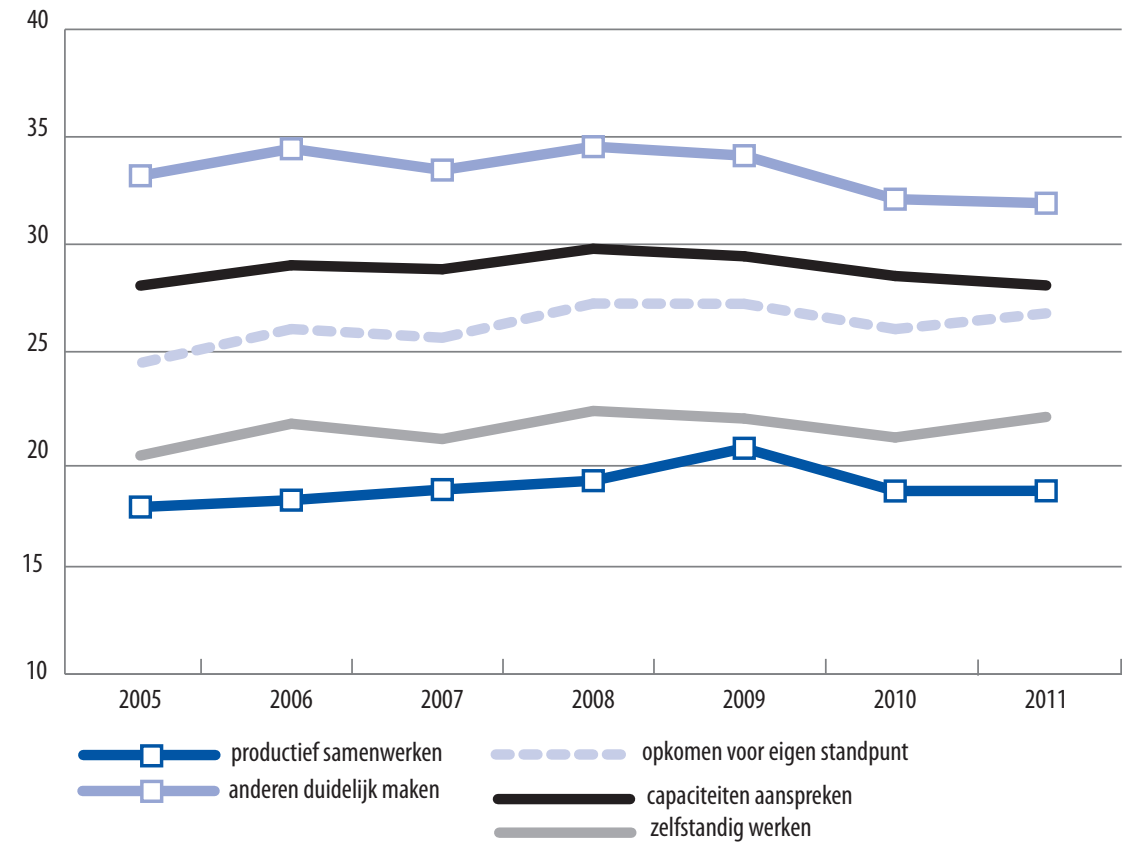

Bron: HBO-Monitor, 2005-2011

Het niveau van tekorten in communicatieve en leidinggevende vaardigheden ligt zorgwekkend hoog. Vooral dat laatste is opvallend, gezien het relatief laag niveau waarop deze competentie wordt vereist. Het lijkt alsof afgestudeerden die deze competentie in hun werk nodig hebben onvoldoende hierop zijn voorbereid.

We zagen al hierboven dat het vereiste niveau aan leidinggevende vaardigheden niet afnam, ondanks een daling in het percentage dat daadwerkelijk leiding geeft (als formeel kenmerk van de functie). Het is interessant om na te gaan of het niveau en/ of de ontwikkeling hierin verschilt tussen mensen die wel en mensen die geen leiding geven. Figuur 6.4 toont dit, voor werkenden binnen hun eigen kerndomein. 
Figuur 6.5

Trend in vereist niveau geselecteerde competenties (uitsluitend afgestudeerden werkzaam in kerndomein)
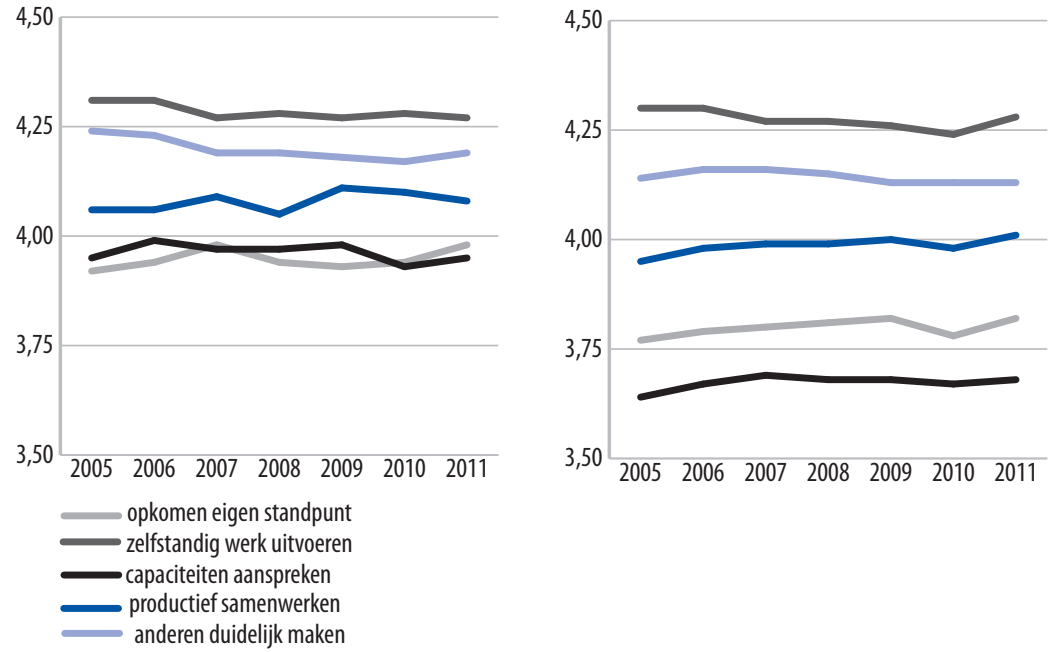

Bron: HBO-Monitor, 2005-2011

Uit figuur 6.5 blijkt dat de enige van de mobilisatiecompetenties waarop een sterk verschil te zien is tussen leidinggevenden en anderen is het vermogen om capaciteiten van anderen aan te spreken. Het is echter ook opvallend dat het vereist niveau van deze competentie alles behalve laag ligt bij mensen die formeel gezien geen leiding geven. Omdat deze de grootste groep is, en omdat het vereist niveau bij deze groep stabiel in de tijd is (en zelfs licht stijgt) verklaart dit waarom deze competentie per saldo niet aan belang inboet. 


\section{Toenemende onzekerheid: de noodzaak om flexibel te zijn}

De voormalige Amerikaanse president Harry S. Truman had een bord op zijn bureau met daarop de spreuk "The buck stops here". Deze spreuk (vrij vertaald: "als alle andere mogelijkheden zijn uitgeput, aanvaard ik de verantwoordelijkheid") lijkt in vele opzichten van toepassing op deze laatste trend. Voor diegenen die erin slagen om de uitdagingen die gepaard gaan met de kennissamenleving, de ICT-revolutie, de globalisering, de veranderende economische structuur en de high-performance organisaties om te zetten in vruchtbare carrièreperspectieven, is de arbeidsmarkt een gelukkige en spannende plek om te vertoeven. Voor diegenen waarvoor dat niet - of minder goed - lukt, blijft slechts een optie over: probeer er het beste van te maken in een onzekere wereld.

In hun beschouwing over deze trend leggen Humburg en Van der Velden (2013) dan ook de nadruk op de keerzijde van de snel veranderende economie en samenleving: een tendens naar een gepolariseerde arbeidsmarkt, met aan de ene kant een gewaardeerde kern van werknemers met gunstige arbeidsomstandigheden en -perspectieven, en aan de andere kant een pool van deeltijders of gedwongen zelfstandigen met weinig of geen werkzekerheid en doorgaans minder gunstige arbeidsvoorwaarden.

Hoewel een zekere flexibiliteit van beide groepen werknemers wordt vereist, is volgens Humburg en Van der Velden de reden en wellicht ook de aard van deze flexibiliteit heel anders voor beide groepen. Bij de groep kernwerkers is de flexibiliteit functioneel en intern. Dat wil zeggen, het betreft de manier waarop hun baan wordt ingericht, niet de vraag of ze volgende maand nog dezelfde baan zullen hebben. Dat laatste is kenmerkend voor de flexibiliteit dat word vereist van de tweede groep.

Hoewel werkgevers in toenemende mate van hun personeel verwachten dat ze flexibel zijn, worden competenties die nodig zijn om flexibel te zijn - zoals het vermogen om nieuwe dingen te leren - vaak slecht beloond. Allen en Van der Velden (2OII) laten zien dat het vooral professionele expertise is dat op de arbeidsmarkt wordt beloond, en niet competenties zoals leervermogen. Dit kan te maken hebben met het feit dat het vooral professionele expertise is waarop de kerngroep zich van de meer gemarginaliseerde en onzekere groep werknemers onderscheiden.

De relatie tussen de bovengenoemde tweedeling en gevoelens van onzekerheid van werknemers wordt fraai geilllustreerd door cijfers van het REFLEX onderzoek. 
Oud-studenten van het Nederlandse $\mathrm{HBO}$ werden onder andere gevraagd om aan te geven in hoeverre hun baan gekenmerkt wordt door een hoge mate van zekerheid. Hoewel over de hele linie ongeveer twee op de drie werkende HBO'ers aangaven dat dit het geval was, bleek dit sterk af te hangen van andere kenmerken van de baan. Figuur 7.I laat dit zien.

\section{Figuur 7.1}

Relatie tussen werkzekerheid en kenmerken van de baan en van de organisatie/het bedrijf

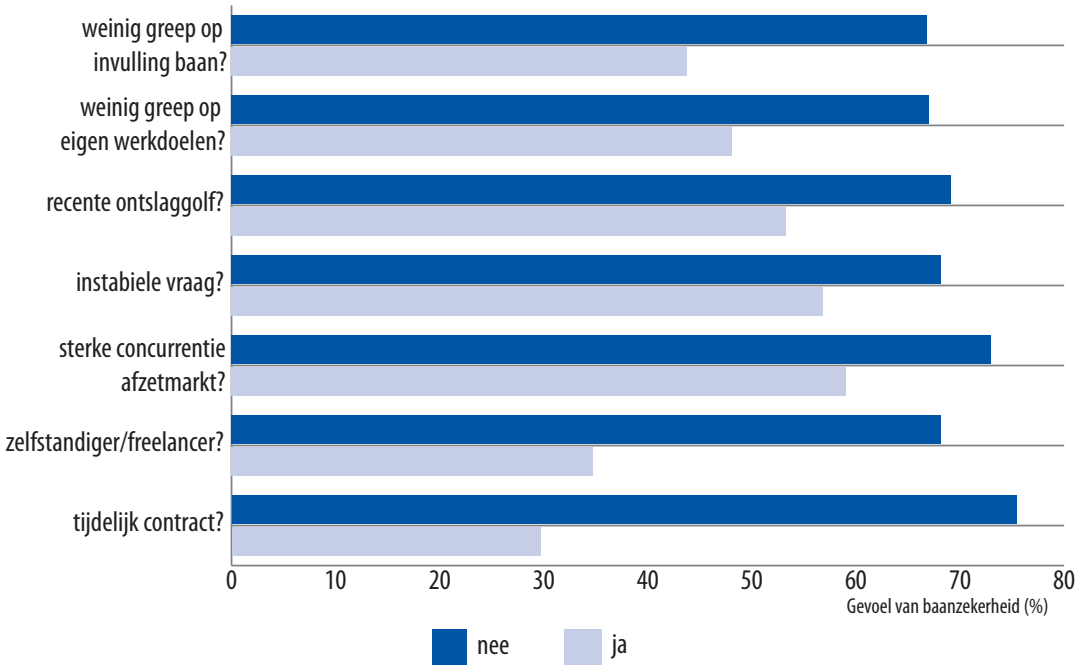

Bron: REFLEX-project

Oud-studenten met een tijdelijk contract, of die voor zichzelf werken, hebben veel minder vaak een sterk gevoel van werkzekerheid dan mensen met een vast contract c.q. die in loondienst zijn bij een bedrijf of organisatie. We zagen al in figuur 5.I dat het percentage zelfstandigen en freelancers de laatste jaren sterk toeneemt, en zoals we straks zullen zien, ligt het percentage afgestudeerden met een tijdelijke aanstelling ook hoog, vooral in tijden van laagconjunctuur. ${ }^{3}$

Ook de omstandigheden op de markt waarop de organisatie opereert hebben een merkbaar effect: sterke concurrentie of instabiliteit in de vraag voor het product of de dienst van de organisatie waarvoor de oud-studenten werken, gaat gepaard met een lager vertrouwen in de zekerheid van de baan. Veel oud-studenten die een recente ontslaggolf bij hun organisatie hebben overleefd, hebben blijkbaar nog altijd niet het volste vertrouwen dat ze uit de problemen zijn. Verder lijkt een lage mate van autonomie in termen van de greep die men heeft op hun eigen werkdoelen en de manier

3. Het is interessant om op te merken dat het werken in deeltijd, in veel landen gezien als teken van een precaire arbeidsmarktsituatie, onder Nederlandse HBO'ers nauwelijks met verminderde gevoelens van werkzekerheid gepaard gaat. 
waarop hun baan wordt ingevuld samen te hangen met een lager niveau van werkzekerheid.

De belangrijkste vrees van mensen met een laag niveau van werkzekerheid is dat ze op een dag helemaal geen baan meer zullen hebben. Figuur 7.2 toont het werkloosheidspercentage van recente afgestudeerden in de tijd.

\section{Figuur 7.2}

Trend in percentage werkloos

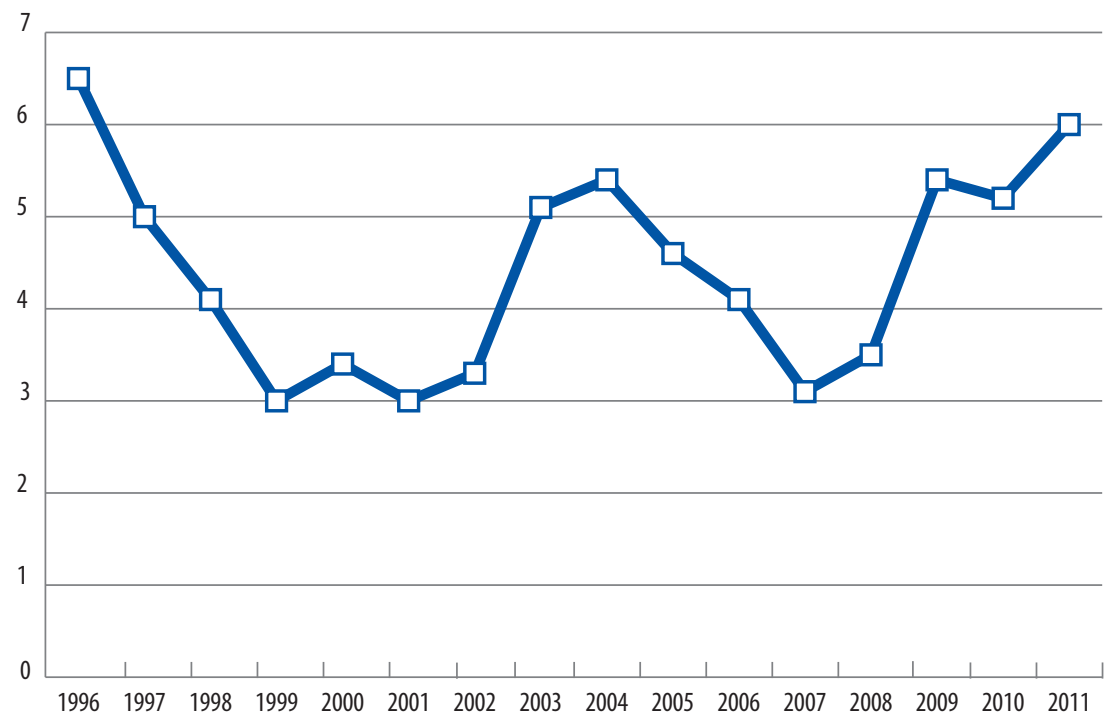

Bron: HBO-Monitor, 1996-2011

Uit figuur 7.2 blijkt dat baanzekerheid vooral een cyclisch karakter heeft: in economisch goede tijden heeft vrijwel iedereen werk, maar in tijden van laagconjunctuur, evenals in de recente economische crisis, wordt het moeilijker voor afgestudeerden om aan een baan te komen. Hierbij kan worden aangetekend dat een werkloosheidspercentage van $6-7 \%$ iets is waar men in veel landen jaloers op zou zijn, zelfs in relatief goede tijden. Verder kan worden opgemerkt dat, hoewel er indicaties zijn dat het betreden van de markt tijdens een economische crisis of recessie in sommige gevallen bepaalde sporen achterlaat, deze effecten na langere tijd ( 5 -IO jaar) verdwijnen (ROA, 2009). Ook voor de huidige groep ziet de toekomst er structureel goed uit, beter dan de jaren '8o.

Figuur 7.2 laat een andere vorm van onzekerheid zien, namelijk het percentage afgestudeerden met een tijdelijke aanstelling. Hieruit blijkt, weinig verassend, dat 
vooral mensen die in het geheel buiten hun kerndomein werken vaak een tijdelijke aanstelling hebben. Interessant is de bevinding dat er nauwelijks een verschil is in dit percentage tussen mensen die geheel in hun kerndomein werken en mensen die binnen de eigen of een verwante richting werken maar op een lagere functieniveau. Wel lijken mensen met een functie waarvoor een $\mathrm{HBO}$ diploma wordt vereist, maar in een andere richting dan die van de afgestudeerde, doorgaans een grotere kans op een tijdelijke aanstelling te hebben.

\section{Figuur 7.3}

Trend in percentage met een tijdelijke aanstelling, naar niveau en richting van de baan

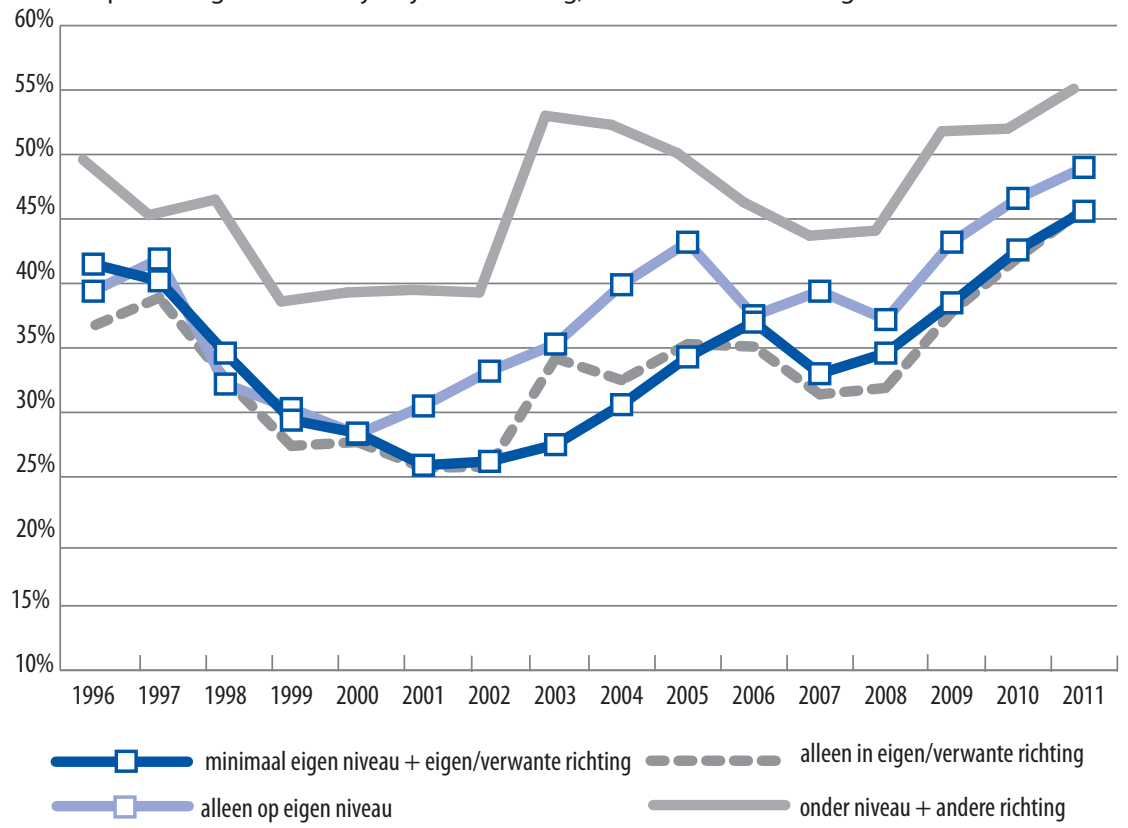

Bron: HBO-Monitor, 1996-2011

Voor alle categorieën geldt dat dit percentage sterk gevoelig is voor de conjunctuur. Hierbij kan worden opgemerkt dat tijdelijke aanstellingen heel gewoon zijn bij de eerste baan. Uit het REFLEX onderzoek is gebleken dat verreweg de meest afgestudeerden 5 jaar na afstuderen inmiddels een vaste aanstelling hebben (zie figuur 7.4). 


\section{Figuur 7.4}

Percentage met een tijdelijke aanstelling eerste baan en vijf jaar na afstuderen

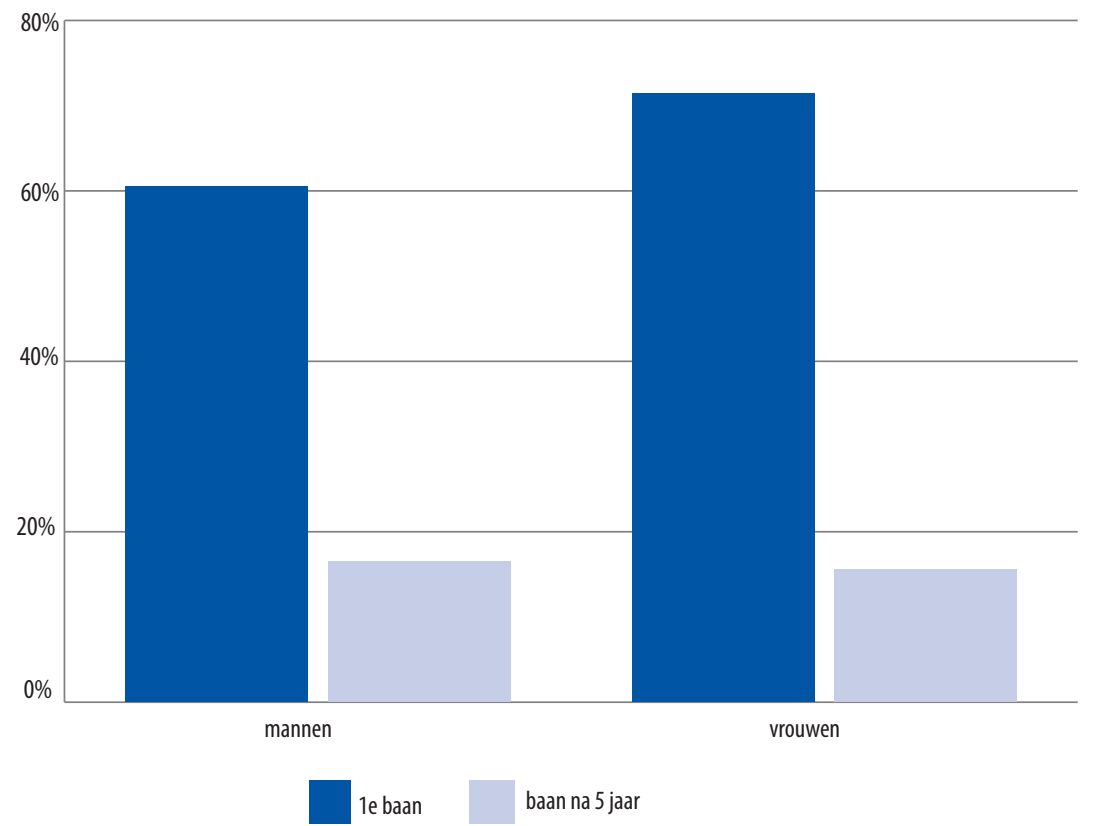

Bron: REFLEX project

Hoe zit het met het vereiste niveau aan competenties die te maken hebben met flexibiliteit? Figuur 7.5 geeft hiervan een beeld voor mensen die in hun kerndomein werkzaam zijn. 


\section{Figuur 7.5}

Trend in vereist niveau geselecteerde competenties (uitsluitend afgestudeerden werkzaam in kerndomein)

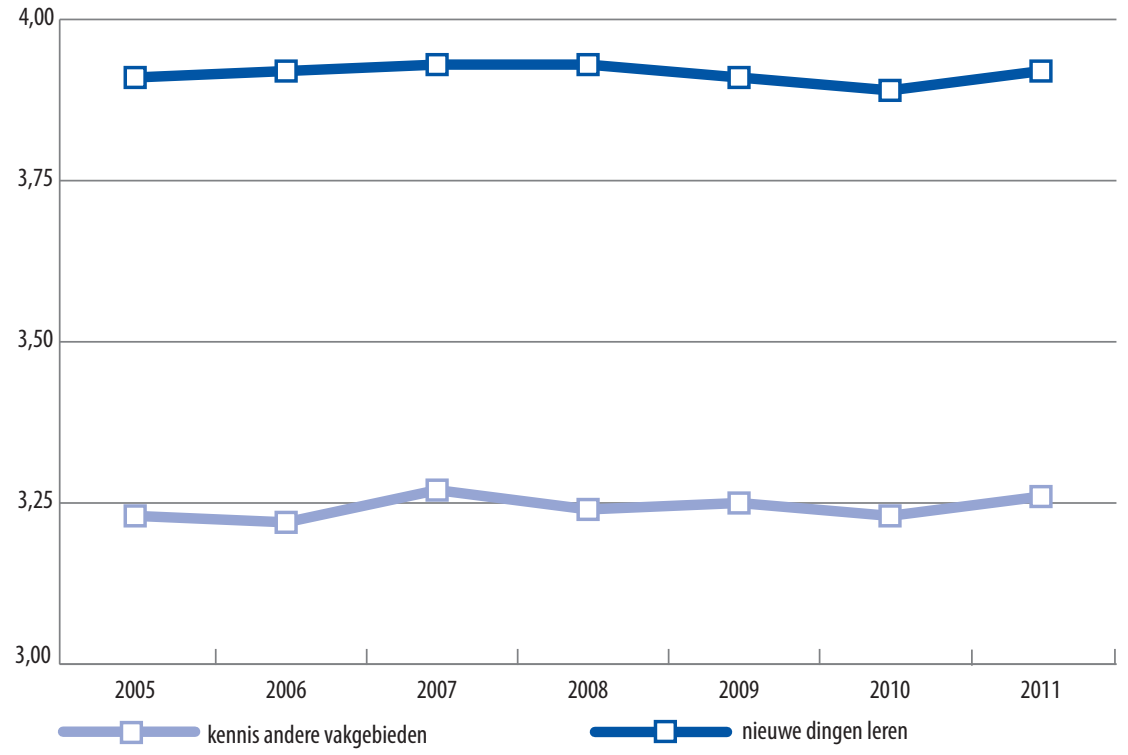

Bron: HBO-Monitor, 2005-2011

Het vereist niveau van beide competenties verandert nauwelijks in de tijd. Er is wel een groot verschil tussen de twee competenties als het gaat om het absolute niveau waarop ze worden vereist. Leercompetenties worden op een tamelijk hoog niveau vereist, terwijl kennis van andere vakgebieden op een veel lager niveau wordt vereist. Op het eerste gezicht lijkt dit logisch: immers, er is waarschijnlijk minder behoefte aan dergelijke interdisciplinaire kennis wanneer men werk heeft waar het vooral om de eigen vakkennis gaat. Echter, uit Figuur 7.6 blijkt dat ook wanneer men buiten de eigen richting werkt, maar dan nog altijd op $\mathrm{HBO}$ niveau, het beeld nauwelijks anders is. Alleen het vereist niveau van het vermogen om nieuwe dingen te leren ligt in dat geval iets lager. Dit laatste suggereert dat deze competentie meer wordt gebruikt om de eigen vakkennis op peil te houden dan om door middel van het aanleren van nieuwe dingen zich uit een ongewenste situatie werken. 


\section{Figuur 7.6}

Trend in vereist niveau geselecteerde competenties (uitsluitend afgestudeerden werkzaam op minimaal niveau maar buiten de eigen opleidingsrichting)

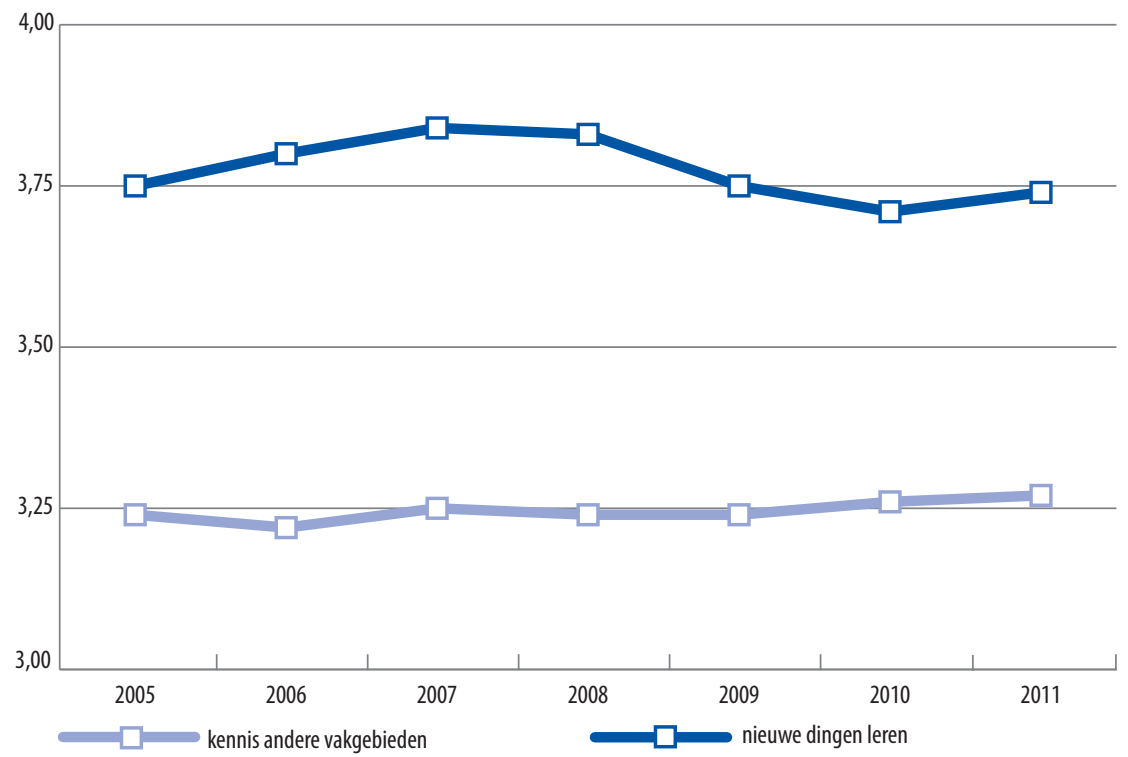

Bron: HBO-Monitor, 2005-2011

Figuur 7.7

Trend in tekorten van geselecteerde competenties (uitsluitend afgestudeerden werkzaam in kerndomein)

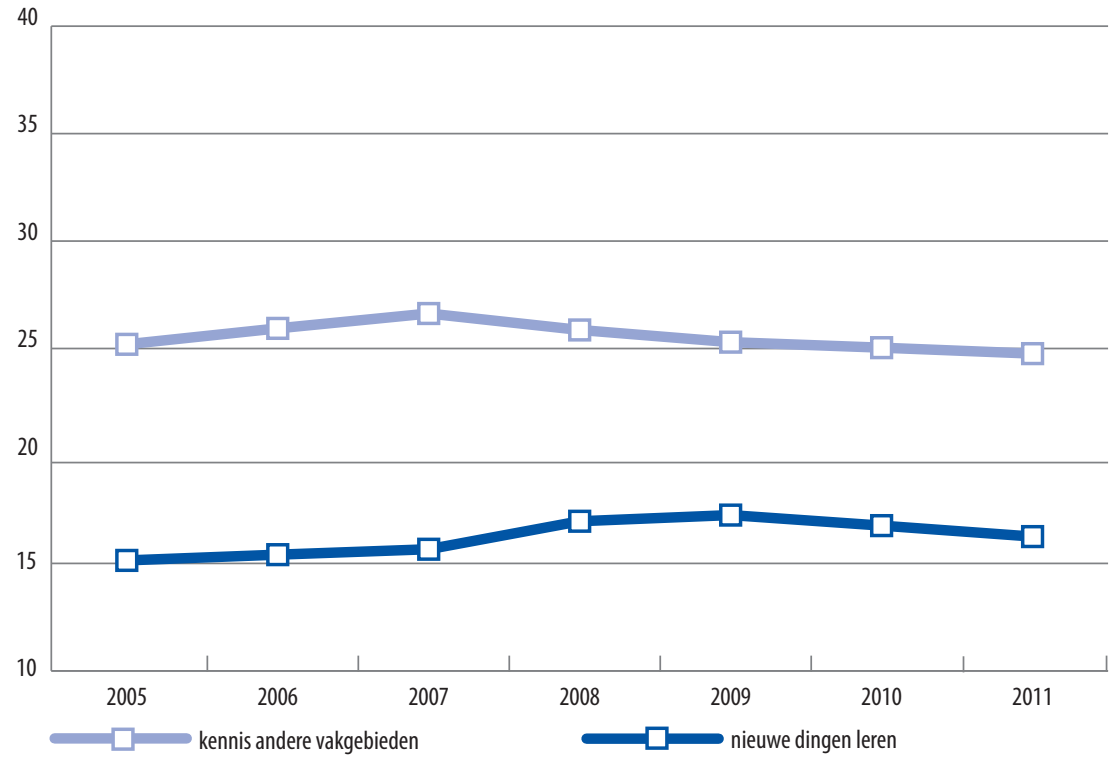

Bron: HBO-Monitor, 2005-2011 
Figuur 7.7 laat de tekorten van deze competenties zien voor mensen die in hun kerndomein werken. Merkwaardig genoeg is het juist de kennis van andere vakgebieden waar de grootste tekorten te zien zijn. Hoewel dit gemiddeld op een relatief laag niveau wordt vereist, komt het blijkbaar relatief vaak voor dat de mensen die deze competentie nodig hebben, er niet over beschikken.

Figuur 7.8 laat zien hoe tekorten aan flexibiliteitscompetenties samenhangt met het soort dienstverband van afgestudeerden.

\section{Figuur 7.8}

Percentage met een tekort aan flexibiliteitscompetenties, tijdelijke versus vaste aanstelling 20052011 (gepoolde data)

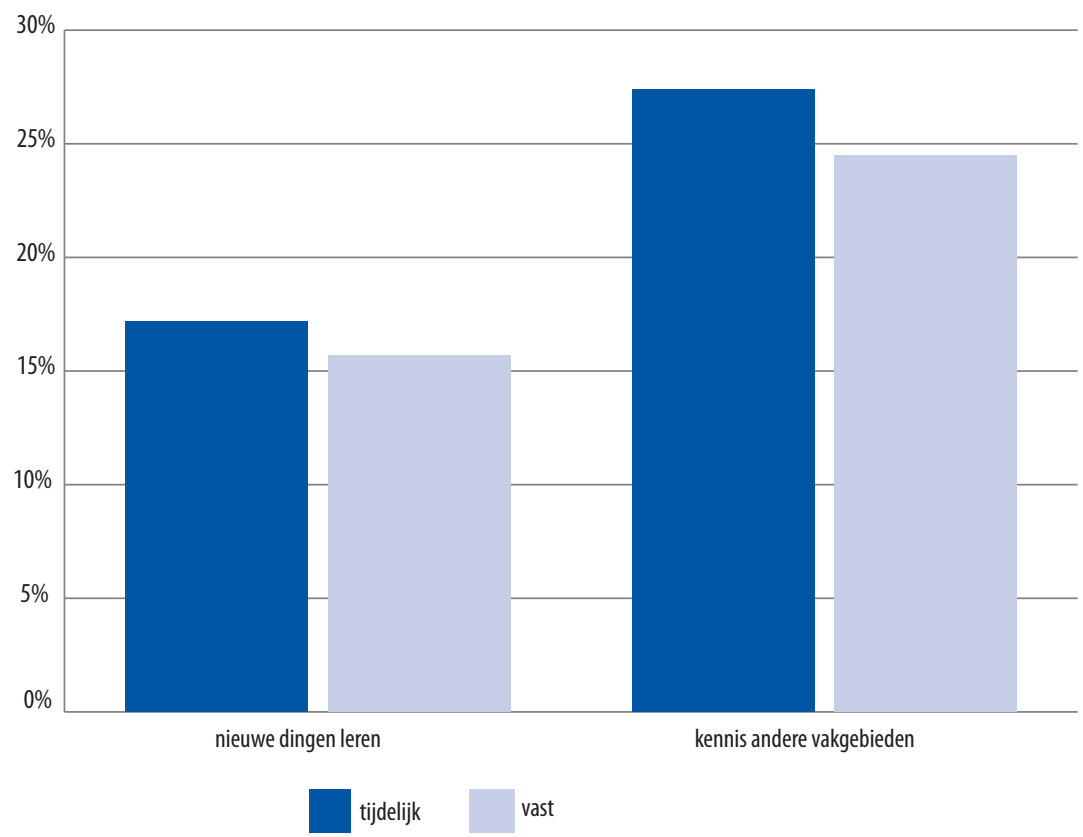

Bron: HBO-Monitor, 2005-2011

In beide gevallen tonen mensen in tijdelijke dienst vaker een tekort dan mensen in vaste dienst. 


\section{Conclusies}

In dit rapport onderzoeken we de gevolgen van een zestal trends die door Humburg en van der Velden (2013) in een recent overzichtsartikel worden aangewezen als in sterke mate bepalend voor de plaats die hoger opgeleiden vervullen in de economie en samenleving. Deze trends zijn: de kennissamenleving, de ICT-revolutie, globalisering, verandering van de economische structuur, high-performance organisaties, en toenemende onzekerheid.

Deze trends hebben in eerste instantie gevolgen voor de type competenties waarover afgestudeerden dienen te beschikken. Voor de kennissamenleving is dit het competentiedomein van de professionele expertise. Een belangrijke bevinding van dit rapport is dat het tijd vergt om expert te worden. De overgrote meerderheid van afgestudeerden vindt dat er aanzienlijk meer tijd nodig is om expert te worden dan de één à twee jaren die zijn verstreken sinds de respondenten van de HBO-Monitor hun opleiding hebben verlaten. Dit impliceert dat op het moment dat de HBO-Monitor enquête wordt afgenomen, de meeste afgestudeerden qua competentieontwikkeling bij lange na niet klaar zijn, maar nog volop bezig.

Expert worden behelst overigens meer dan alleen vakkennis, maar ook het vermogen om als expert te denken en te beschikken over brede academische vaardigheden. Verder dienen Nederlandse professionals in staat te zijn om adequaat om te gaan met de wet- en regelgeving waarmee ze in toenemende mate worden geconfronteerd. Met name dit laatste blijkt steeds belangrijker te worden, hoewel in absolute zin het nog altijd minder belangrijker lijkt te zijn dan vakkennis en vooral academische vaardigheden.

Wanneer we kijken naar de mate waarin het $\mathrm{HBO}$ met de eisen omtrent professionele expertise om weet te gaan, zien we dat vooral op het punt van vakkennis de tekorten fors zijn. Een nadere analyse van deze tekorten en ook surplussen leert dat deze vaak in een lagere beloning resulteren. Ook het oordeel van afgestudeerden over de aansluiting tussen de $\mathrm{HBO}$-opleiding en hun werk is beduidend minder positief wanneer het eigen niveau van vakkennis afwijkt van wat op het werk wordt vereist. Voor andere indicatoren van baankwaliteit blijkt echter dat lichte tekorten geen echt probleem vormen, en voor wat betreft de gepercipieerde carrièremogelijkheden zelfs een licht voordeel opleveren. Dit lijkt een bevestiging te geven dat lichte tekorten tot op zekere hoogte een indicatie zijn van een dynamische en uitdagende werkomgeving. 
Hoewel de ICT-revolutie doorwerkt op vrijwel alle aspecten van competentievereisten, is het effect het meest direct merkbaar op competenties op het gebied van innovatie en kennismanagement. Vanzelfsprekend wordt hierdoor meer een beroep gedaan op ICT-vaardigheden zelf, maar ook op het vermogen om informatie te vergaren en het vermogen om nieuwe ideeën en oplossingen te bedenken.

Uit de in dit rapport gepresenteerde analyses blijkt dat het vereist niveau van ICT-competenties sinds 2005 merkbaar is gestegen voor afgestudeerden werkzaam binnen hun kerndomein. Deze stijging vertaalt zich in een stijging in het percentage afgestudeerden met een tekort aan deze competenties. Deze stijging is echter heel licht, en het niveau van de tekorten ligt nog vrij laag, in $201 \mathrm{I}$ nog minder dan $20 \%$. Er lijkt op dit punt vooralsnog geen reden voor HBO-instellingen om zware maatregelen te treffen om dit stijgende tekort te lijf te gaan, gezien het feit dat de meeste jongeren tegenwoordig min of meer vanzelf in aanraking komen met ICT, in zowel de privésfeer als op school. Er lijkt eerder een iets andere les te trekken uit het stijgende belang van ICT, namelijk dat bestaande functies door toenemend ICT gebruik worden getransformeerd.

Globalisering heeft eveneens een rimpelwerking dat vergaande consequenties kan hebben zelfs voor mensen die er niet direct mee te maken krijgen. Het meest voor de hand liggend directe effect is op de internationale oriëntatie van werknemers. Dit zou betekenen dat kennis van buitenlandse talen belangrijker wordt, evenals de bereidheid om begrip te tonen voor andere standpunten, in dit geval van mensen met een andere culturele achtergrond.

Op het eerste gezicht lijken de directe gevolgen van de globalisering voor het $\mathrm{HBO}$ relatief beperkt. In tegenstelling tot het WO stijgt de instroom van buitenlandse studenten in het HBO heel langzaam. Wel brengen HBO'ers steeds vaker een deel van de studie in het buitenland door. Ondanks deze toename in buitenlandervaring tijdens de studie lijkt er echter geen sprake van te zijn dat meer Nederlandse HBO'ers na afronding van de studie ervoor kiezen om in het buitenland te werken. Dit percentage daalt zelfs de laatste jaren, na een korte opleving in het begin van het vorige decennium. Als relativering van deze cijfers kan worden opgemerkt dat ongeveer een derde van alle HBO'er vijf jaar na afstuderen in een organisatie werkt met een internationale reikwijdte.

Hoe zit het met de competenties op het gebied van internationale orientatie? Hierbij kan worden gedacht aan kennis van buitenlandse talen, maar ook de bereidheid om begrip tonen voor andere standpunten, met name voor mensen met een andere culturele achtergrond. Het vereiste niveau van deze laatste competentie ligt stabiel erg hoog. Dat van buitenlandse talenkennis ligt veel lager, maar is merkbaar gestegen in de afgelopen zes jaren. Deze stijging vertaalt zich in een lichte stijging in het aandeel afgestudeerden met een tekort aan talenkennis. 
Zoals zou worden verwacht hangt het vereist niveau van taalvaardigheden sterk samen met het wel of niet in het buitenland werken. Opvallend is echter dat de algemene stijging in het vereist niveau in het geheel wordt bepaald door mensen in Nederland werken. Dit laat zien dat ook in Nederland het werk steeds internationaler wordt.

De verandering van de economische structuur leidt tot een toenemend belang van ondernemerschapscompetenties. Hierbij kan worden gedacht aan het vermogen om onder druk goed te functioneren, om knopen door te hakken en de bereidheid de eigen nek uit te steken.

$\mathrm{Na}$ jarenlang op een laag niveau te hebben gezeten is het percentage afgestudeerden dat voor zichzelf werkt de laatste vijf jaren fors gestegen. Opvallend is dat dit vooral geldt vooral voor mensen die op eigen niveau werkzaam zijn buiten hun eigen richting. Hoewel dit deels wordt bepaald door extreme percentages voor de sector KUO, is de stijging ook bij de meeste andere sectoren zichtbaar. De stijging is al ruim vóór de crisis in 2008 uitbrak is begonnen, en kan daarom niet geheel daaraan toegeschreven worden, al heeft het ongetwijfeld een effect gehad. Omdat zelfstandigen/freelancers overwegend in kleine organisaties werken, is ook het percentage afgestudeerden dat in een kleine organisatie werkt duidelijk toegenomen in de afgelopen io jaar.

Uit het REFLEX-onderzoek blijkt dat slechts I6\% van de HBO'ers hun opleiding een goede voorbereiding vond op het gebied van het ontwikkelen van ondernemerschapsvaardigheden. Desalniettemin blijken ondernemerschapscompetenties doorgaans op hoog niveau te worden vereist. Het maakt het voor het vereist niveau van ondernemerschapscompetenties weinig uit of men buiten de eigen richting werkt, zolang als het nog om een HBO functie gaat. Dit suggereert dat ondernemerschap een sterk generieke kenmerk is. Het hoge vereiste niveau vertaalt zich in een relatief hoog aandeel afgestudeerden dat met een tekort aan deze competenties kampt. Vooral onder mensen die in kleine organisaties werken lijken deze competenties belangrijker te worden in de tijd.

High-performance organisaties vereisen vooral een hoog niveau van competenties op het gebied van het mobiliseren van menselijke hulpbronnen. Dit houdt in dat men de eigen werkzaamheden zelfstandig dient te kunnen uitvoeren, en in staat is om met anderen productief samen te werken, aan hen uit te leggen wat de bedoeling is, en waar nodig aan te sturen en op te komen voor het eigen standpunt.

Wellicht een weerspiegeling van de trend naar nieuwe organisatievormen is de dalende trend in het percentage HBO'ers dat leiding geeft. Wel blijkt het werk van afgestudeerden een sterke mate van onderlinge afhankelijkheid te vertonen met andere werknemers in de organisaties waarin ze werken.

Zoals wellicht zou worden verwacht gezien het relatief lage percentage afgestudeerden dat leiding geeft, ligt het vereiste niveau van het vermogen om capaciteiten 
van anderen aan te spreken het laagst van de mobilisatiecompetenties. Opvallend is echter dat het gemiddeld niveau van deze competentie niet daalt, ondanks de daling in het percentage leidinggevenden. Dit ligt aan het feit dat het vereist niveau van deze competentie alles behalve laag ligt bij mensen die formeel gezien geen leiding geven. Met name voor de communicatieve en leidinggevende vaardigheden ligt het aandeel afgestudeerden met een tekort zorgwekkend hoog. Vooral dat laatste is opvallend, gezien het relatief laag niveau waarop deze competentie wordt vereist. Het lijkt alsof afgestudeerden die deze competentie in hun werk nodig hebben onvoldoende hierop zijn voorbereid.

Toenemende onzekerheid is in veel opzichten - hoewel niet uitsluitend - de negatieve keerzijde van veel van de andere trends. Dit betekent vooral dat mensen in staat moet zijn om flexibel te reageren op alles wat ze in hun werk of carrière tegenkomen. Er zijn veel manieren waarmee deze flexibiliteit te realiseren kan zijn, maar het is aannemelijk dat vooral kennis van andere vakgebieden en het vermogen om nieuwe dingen te leren de opties van mensen zal vergroten wanneer onverwachte ontwikkelingen zich voordoen.

Uit het REFLEX onderzoek blijkt dat oud-studenten met een tijdelijk contract, of die voor zichzelf werken, veel minder vaak een sterk gevoel van werkzekerheid hebben dan mensen met een vast contract c.q. die in loondienst zijn bij een bedrijf of organisatie. Ook concurrentie, marktinstabiliteit en recente ontslaggolven gaan gepaard met een lager vertrouwen in de zekerheid van de baan. Verder lijkt een lage mate van autonomie samen te hangen met een lager niveau van werkzekerheid.

Wanneer we naar de objectieve situatie kijken blijkt dat baanzekerheid vooral een cyclisch karakter heeft. Dit geldt ook voor het percentage afgestudeerden met een tijdelijk contract. Uit het REFLEX onderzoek is echter gebleken dat verreweg de meest afgestudeerden 5 jaar na afstuderen inmiddels een vaste aanstelling hebben.

Het vereist niveau van kennis van andere vakgebieden en het vermogen om nieuwe dingen te leren verandert nauwelijks in de tijd. Er is wel een groot verschil tussen de twee competenties als het gaat om het absolute niveau waarop ze worden vereist. Leercompetenties worden op een tamelijk hoog niveau vereist, terwijl kennis van andere vakgebieden op een veel lager niveau wordt vereist. Merkwaardig genoeg is het juist de kennis van andere vakgebieden waar de grootste tekorten te zien zijn. Hoewel dit gemiddeld op een relatief laag niveau wordt vereist, komt het blijkbaar relatief vaak voor dat de mensen die deze competentie nodig hebben, er niet over beschikken. In beide gevallen tonen mensen in tijdelijke dienst vaker een tekort dan mensen in vaste dienst. 


\section{Wat kunnen we hieruit leren?}

In de voorgaande zes hoofdstukken zijn de resultaten gepresenteerd van een reeks analyses, met als doel om licht te werpen op de gevolgen van zes belangrijke trends voor de arbeidsmarktpositie van afgestudeerden van het Nederlandse HBO. In dit hoofdstuk wordt mede aan de hand van de gepresenteerde resultaten een poging gedaan om conclusies hieruit te trekken voor het hoger onderwijsbeleid in Nederland. Vooraf dient ondubbelzinnig duidelijk te worden gemaakt dat het hierbij gaat om een eigen interpretatie van de resultaten door het ROA, en niet om onomstotelijke conclusies die zonder meer direct uit de onderzoeksresultaten volgen. Deze eigen meningen zijn bedoeld als een beginpunt voor nadere discussies van deze kwesties, en beslist niet als het laatste woord.

\section{Specialisten of generalisten? Onderschat het belang van specifieke kennis niet}

Humburg en Van der Velden (2013) merken op dat het (te) gemakkelijk is om de conclusie te trekken dat vakkennis minder belangrijk is geworden vanwege de snelle veranderingen in de economie en samenleving. Veel kennis is immers vrij beschikbaar via internet, en de snelle technologische veranderingen betekenen dat de kennis van vandaag morgen wellicht al verouderd is. Vele mensen pleiten voor een hoger onderwijssystem dat vooral gericht is op het voortbrengen van generalisten. Volgens hen is dit een misvatting. Een stevige basis van vakkennis is onmisbaar voor het oplossen van de problemen waarmee professionals dagelijks worden geconfronteerd op hun werk. Deze relevantie wordt onderstreept door bevindingen van vele onderzoeken, waarin keer op keer professionele expertise naar voren komt als de belangrijkste determinant van arbeidsmarktsucces (Allen, Pavlin en Van der Velden, 20II; Allen en Van der Velden, 20II). Ondanks - of wellicht mede dankzij - alle grote veranderingen die plaatsvinden, blijft het aanleren van vakkennis daarom hét belangrijkste doel voor het HBO. Uit dit rapport blijkt ook dat zowel vakkennis als de meer academische competenties die een professioneel expert nodig heeft op een zeer hoog niveau worden vereist in het werk van de meeste afgestudeerden. Vooral in het geval van vakkennis vertaalt dit zich in een erg hoog percentage afgestudeerden met een tekort - dat wil zeggen een lager eigen niveau dan in de functie wordt vereist - aan deze competentie. Hoewel zulke tekorten lang niet altijd de $\mathrm{HBO}$-opleiding kan worden aangerekend, en in vele opzichten een gevolg zijn van het feit dat afgestudeerden erin slagen om dynamisch en uitdagend werk te vinden, kunnen $\mathrm{HBO}$-instellingen het zich niet permitteren om de aandacht voor het produceren van vakbekwame professionals te laten verslappen. 
Tekorten aan vakkennis gaan immers gepaard met een lagere beloning en een minder positief oordeel over de aansluiting tussen de opleiding en het werk.

\section{Laat noodzakelijke specialisatie niet doorslaan in modieuze differentiatie}

De noodzaak om goed opgeleide specialisten te produceren betekent allerminst dat een vergaande differentiatie tussen opleidingen wenselijk is. In tegendeel: het is van groot belang dat het aantal bachelor opleidingen in het $\mathrm{HBO}$ wordt teruggebracht tot een overzichtelijk aantal brede herkenbare opleidingen van goede kwaliteit. Hierover dienen landelijke afspraken per sector gemaakt te worden. Binnen deze opleidingen zal bijvoorbeeld $70 \%$ landelijk vergelijkbaar moeten zijn en kunnen instellingen en studenten zelf invulling geven aan de overige $30 \%$. Informeel geldt een dergelijke norm al bij de accreditatie van (nieuwe) opleidingen, en het bepalen of deze vergelijkbaar zijn met andere opleidingen met dezelfde naam. Dit maakt het makkelijker om de kwaliteit te bewaken, het voorkomt modieuze opleidingen zonder arbeidsmarktrelevantie, het beperkt de uitval, het vergroot de transparantie en het komt ook tegemoet aan wensen tot eigen invulling. Dat neemt niet weg dat het nodig kan blijven om in bepaalde uitzonderingsgevallen een smallere opleiding te maken.

\section{Professionele expert worden kost tijd}

Uit het REFLEX-project blijkt dat er voor de overgrote meerderheid van afgestudeerden aanzienlijk meer tijd nodig is om expert te worden dan de één a twee jaren die zijn verstreken sinds de respondenten van de HBO-Monitor hun opleiding hebben verlaten. Één van de consequenties hiervan is dat recent afgestudeerden qua competentieontwikkeling bij lange na niet klaar zijn, maar nog volop bezig. Dit betekent dat afgestudeerden goed in staat dienen te zijn om hun kennis en vaardigheden te blijven ontwikkelen "on-the-job”. Het is in dat opzicht goed nieuws dat afgestudeerden doorgaans juist een heel positief oordeel vellen over de $\mathrm{HBO}$-opleiding als basis voor het verder ontwikkelen van kennis en vaardigheden, vooral wanneer het eigen niveau van hun professionele competenties overeenkomt met het niveau dat in de baan wordt vereist. Interessant hierbij is dat de tevredenheid hierover meer wordt aangetast door tekorten (en ook surplussen) van academische vaardigheden dan door tekorten aan vakkennis, die meer bepalend blijken te zijn voor tevredenheid met de opleiding als basis om te starten op de arbeidsmarkt. De uitdaging voor opleidingen is derhalve tweeledig: zorg ervoor dat de afgestudeerden een stevige basis aan vakkennis wordt meegegeven, zodat ze een vlotte start kunnen maken als ze de collegebanken verlaten en de arbeidsmarkt betreden, maar zorg ervoor dat dit gepaard gaat met sterk ontwikkelde analytische en reflectieve competenties, die ze hard nodig hebben om op deze basis te blijven bouwen. 
Een professional heeft uiteraard meer nodig dan alleen vakkennis en academische vaardigheden. Alle denkbare competenties kunnen belangrijk zijn voor bepaalde groepen afgestudeerden, en expertise heeft in iedere opleidingssector en in iedere type organisatie zijn eigen specifieke karakter. Het is belangrijk voor het $\mathrm{HBO}$ om niet te veel toe te geven aan de druk uit sommige richtingen naar meer "one-size-fits-all" opleidingen. Zoals Humburg en Van der Velden (2013) opmerken, zijn er geen indicaties dat werkgevers op zoek zijn naar werknemers die in alles een beetje goed zijn. Het $\mathrm{HBO}$ dient een goede mix aan competenties voort te brengen, maar dit is meer op het niveau van de arbeidsmarkt als geheel dan op het niveau van individuele werknemers.

\section{ICT verandert alles, ook in het onderwijs}

Uit dit rapport blijkt dat het vereist niveau van ICT-competenties sinds 2005 merkbaar is gestegen voor afgestudeerden werkzaam binnen hun kerndomein. De belangrijkste les die hieruit kan worden getrokken is echter niet dat opleidingen per se meer aandacht moeten besteden aan basisvaardigheden in ICT voor hun studenten. Immers, de meeste jonge mensen komen vanzelf voldoende in aanraking met ICT, en in de meeste gevallen zullen ze weinig van hun docenten hierover kunnen leren. Een uitzondering vormen de meer strategische ICT vaardigheden en de vakspecifieke hardware en/of software. Maar het is vooral van groot belang om in te haken op de talloze manieren waarop ICT kan worden gebruikt om het onderwijs te verbeteren. Dit is vooral van belang in de sector HPO, waar de afgestudeerden zelf voor de uitdaging staan om hun ICT vaardigheden effectief aan te wenden wanneer ze voor de schoolklas komen te staan. Door ICT is het immers mogelijk om persoonlijke leerplannen op te zetten die geïntegreerd worden in interactieve leeromgevingen (eventueel met een e-docent). Deze individuele leeromgevingen worden onderling met elkaar verbonden zodat het mogelijk is om samenwerkingsprojecten uit te voeren, hetgeen de mogelijkheden voor 'informeel leren' vergroot (ECJRC, 20II). Door het gebruik van moderne technologie rukken bovendien gemeenschappen van onderwijswerkers op die samen curricula ontwikkelen en ze toegankelijk maken via 'open resources'. Leraren kunnen kiezen uit materiaal dat al ergens anders ontwikkeld is. Studenten kunnen colleges volgen van de beste docenten ter wereld (Allen en Van der Velden, 20I2). Toch is het aandeel leraren dat zich volledig bewust is van de didactische mogelijkheden van ICT vrij laag (Kennisnet, 20IO). Dit geldt ook voor een meerderheid van docenten die aan $\mathrm{HBO}$-instellingen onderwijs verzorgen.

\section{Het HBO moet internationaler worden}

Ondanks het feit dat HBO'ers niet vaak in het buitenland werken betekent dit niet dat ze niet internationaal georiënteerd hoeven te zijn. Uit het REFLEX onderzoek bleek dat in 2005 ongeveer een derde van Nederlandse HBO'ers 5 jaar na afstuderen in een organisatie werkte met een internationale reikwijdte. Uit het feit dat het vereist 
niveau van kennis van buitenlandse talen de laatste jaren sterk stijgt juist onder afgestudeerden die in Nederland werken, kan worden geconcludeerd dat het werken in Nederland steeds internationaler wordt. Hoewel dit tot een stijging in de tekorten aan taalkennis heeft geleid, heeft dit vooralsnog niet een niveau bereikt waar men zich over de hele linie zorgen over hoeft te maken. Wel is van belang om dit per opleiding en per instelling nauwlettend in de gaten te houden, omdat er zich "lokale" problemen kunnen voordoen. Vereiste talenkennis is echter wat betreft internationalisering waarschijnlijk slechts het topje van de ijsberg. Om effectief om te kunnen gaan met buitenlandse klanten, collega's, patiënten, leerlingen en zo voorts, is de kennis van andere landen en het vermogen om begrip te tonen voor andere culturele gewoontes waarschijnlijk veel belangrijker.

\section{Het ondernemerschap rukt op}

$\mathrm{Na}$ jarenlang op een laag niveau te hebben gezeten is het percentage afgestudeerden dat voor zichzelf werkt de laatste vijf jaren fors gestegen. Het is van groot belang dat het $\mathrm{HBO}$ hiermee voldoende rekening houdt. Uit het REFLEX onderzoek bleek dat Nederlandse HBO'ers niet erg te spreken waren over de opleiding als een basis om ondernemerschapscompetenties aan te leren. Het wekt daarom weinig verbazing om te zien dat er een tamelijk sterk tekort is aan competenties die verwant zijn aan het begrip ondernemerschap, zoals het vermogen om problemen/kansen te signaleren, en deze competenties blijken inderdaad speciaal van belang te zijn bij mensen die voor zichzelf werken. Ook bij het toenemend deel van de $\mathrm{HBO}$ afgestudeerden die in kleinere organisaties werken worden deze competenties steeds belangrijker.

\section{De werkplek van HBO'ers verandert}

Over de hele linie blijkt het werk van bijna de helft van de oud-studenten gekenmerkt te zijn door een hoge mate van onderlinge afhankelijkheid. Tevens zien we een daling in het aandeel afgestudeerden die direct leiding geeft aan anderen. Deze bevindingen lijken ondersteuning te bieden aan de stelling dat er een tendens is naar meer "highperformance" organisaties, waarin semi-autonome teams zichzelf en elkaar dienen aan te sturen en te coördineren. Ondanks de daling in het aandeel leidinggevenden zien we een lichte stijging in het vereiste niveau van het vermogen om capaciteiten van anderen aan te spreken. Ook niet-leidinggevenden blijken in toenemende mate over zulke vaardigheden te moeten beschikken, naast het blijvend sterk belang van andere inter- en intrapersoonlijke vaardigheden. Het is daarom van groot belang dat het $\mathrm{HBO}$ zich inspant om mensen optimaal voor te bereiden op het functioneren in deze high-performance organisaties, vooral door effectief gebruik te maken van innovatieve onderwijsmethodes. 
Oud-studenten met een tijdelijk contract, of die voor zichzelf werken, hebben veel minder vaak een sterk gevoel van werkzekerheid dan mensen met een vast contract c.q. die in loondienst zijn bij een bedrijf of organisatie. Zoals al is opgemerkt neemt het percentage zelfstandigen en freelancers de laatste jaren enorm toe. Het percentage afgestudeerden met een tijdelijke aanstelling ligt ook hoog, vooral in tijden van laagconjunctuur. Tevens kan het gevoel van zekerheid op de proef worden gesteld door de omstandigheden op het werk, bijvoorbeeld sterke concurrentie of instabiliteit in de vraag naar de product of dienst van de organisatie waar ze werken, een recente ontslaggolf, of een lage mate van werkautonomie. Het is van belang dat het $\mathrm{HBO}$ zijn studenten op een goede manier hierop voorbereidt, zodat ze als ze eenmaal de opleiding hebben verlaten zich niet te veel hierdoor laten afschrikken. Hoewel een tijdelijke eerste baan heel gewoon is blijkt uit het REFLEX onderzoek dat verreweg de meeste afgestudeerden 5 jaar na afstuderen inmiddels een vaste aanstelling hebben. Het overbrengen van het besef dat, hoewel de tijden waarin we leven in bepaalde opzichten onzekerder worden, men geen grote angst hoeft te koesteren voor het onbekende, dient een integraal deel uit te maken van de voorlichting over de arbeidsmarkt die aan studenten wordt meegegeven. 



\section{Literatuur}

ABN Amro (2011), Visie op zakelijke dienstverlening, mei 2011.

Allen, J. en A. de Grip (2012). Skill Obsolescence, Lifelong Learning and Labor Market Participation, Applied Economics, vol. 44 (25), 3237-3245.

Allen, J., Pavlin, S. and Van der Velden, R. (eds.) (2011). Competencies and Early Labour Market Careers of Higher Education Graduates in Europe. University of Ljubljana: Faculty of Social Sciences.

Allen, J. and Van der Velden, R. (2012). Skills for the 21st Century: Implications for Education. Essay for the Kenniskamer of the Ministry of Education, Culture and Science. ROARM-2012/11, Maastricht: Research Centre for Education and the Labour Market.

Allen, J. and Van der Velden, R. (2011). The Flexible Professional in the Knowledge Society: New Challenges for Higher Education. Dordrecht, Heidelberg, London, New York: Springer.

ANP (2012), Leraar voor de klas, HBO-raad, Algemeen Nederlands Persbureau (ANP), 2001-2012.

Appelbaum, E., Bailey, T., Berg, P. and Kalleberg, A.L. (2000). Manufacturing Advantage: Why High-Performance Work Systems Pay Off. Ithaca, N.Y.: ILR Press

Arnal, E., Ok, W. and Torres, R. (2001). Knowledge, Work Organisation and Economic Growth, OECD Labour Market and Social Policy Occasional Papers, 50, Paris: OECD Publishing.

Bartel, A. P. (2004). Human Resource Management and Organizational Performance: Evidence from Retail Banking. Industrial and Labor Relations Review, 57, 1, 181-202.

Bell, D. (1973) The Coming of Post-Industrial Society: A Venture in Social Forecasting, New York: Basic Books.

Betcherman, G. (1997). Changing Workplace Strategies: Achieving Better Outcomes for Enterprises, Workers and Society. Ottawa: Government of Canada and OECD.

Bills, D.B. (2004). The Sociology of Education and Work. Malden, Oxford and Victoria : Blackwell.

Black, S. E. and Lynch, L. M. (2004). What's driving the New Economy: the benefits of workplace innovation. Economic Journal, 117, 97-116.

Carlsson, B. (1989). The Evolution of Manufacturing Technology and its Impact on Industrial Structure: An International Study. Small Business Economics, 1, 21-37.

Carlsson, B. (1992). The Rise of Small Business: Causes and Consequences. In W.J. Adams (ed.) Singular Europe, Economy and Policy of the European Community after 1992. Ann Arbor, MI: University of Michigan Press, pp. 145-169.

Carlsson, B. (1999). Small Business, Entrepreneurship, and Industrial Dynamics. In Z. Acs (ed.), Are Small Firms Important? Boston/Dordrecht: Kluwer Academic Publishers, 99-110. 
Caroli, E. and Van Reenen, J. (2001). Skill-Biased Organizational Change: Evidence From A Panel Of British and French Establishments. The Quarterly Journal of Economics, 116, 4, $1449-1492$.

Castells, M. (2000). The Rise of the Network Society ( $2^{\text {nd }}$ edition). Cambridge, MA, Oxford: Blackwell.

Dede, C. (2010). Comparing Frameworks for 21 st Century Skills. In J. Bellanca and R. Brandt (eds.) 21st Century Skills. Bloomington, IN: Solution Tree Press, 51-76.

Dekker, H., Vonk, R., Vries, C.W. de, Wagenaar, S. \& Renekers, N.C.F (2002), Vraagsturing als competentie. Eindrapportage. Utrecht: Kessels \& Smit, The Learning Company.

ECJRC (2011), The Future of Learning: Preparing for Change, Institute for Prospective Technological Studies, JRC Scientific and Technical Reports, European Commission Joint Research Centre (ECJRS), JRC Publication nr: JRC66836.

Ericsson, K.A. and Crutcher, R.J. (1990). The Nature of Exceptional Performance. In: P.B. Baltes, D.L. Featherman and R.M. Lerner (eds.), Life-Span Development and Behavior. Hillsdale, NJ: Lawrence Erlbaum.

Financieel Dagblad (12 januari 2012) Groeiend tekort aan technisch specialisten [elektronische versie] http://fd.nl/Print/krant/Pagina/Ondernemen/652261-1201/groeiend-tekort-aantechnisch-specialisten_bron_fd_krant, 12-01-2012.

Hage, J., and Powers, C.H. (1992). Post-Industrial Lives: Roles and Relationships in the $21^{s t}$ Century. Newbury Park: Sage.

Hayes, J. (1981). The Complete Problem Solver. Philadelphia: The Franklin Institute Press.

HBO-raad (2010), Branchejaarverslag hbo 2009, Den Haag.

Johnson, L., Levine, A., Smith, R. and Stone, S. (2010). The 2010 Horizon Report. Austin, Texas: The New Media Consortium.

Hujer, R., Caliendo, M. and Radic, D. (2002). Skill Biased Technological and Organizational Change: Estimating a Mixed Simultaneous Equation Model Using the IAB Establishment Panel. IZA Discussion Paper No 566, Bonn: IZA.

Humburg, M. en R. van der Velden (2013), What Is Expected from Higher Education Graduates in the 21 st Century? Te verschijnen in: John Buchanan, David Finegold, Ken Mayhew and Chris Warhurst (eds.), Oxford University Handbook of Skills and Training.

Karoly, L. A. (2004). The 21st Century at Work: Forces Shaping the Future Workforce and Workplace in the United States. Santa Monica, CA: RAND Corporation.

Kennisnet (2010), Vier in Balans Monitor 2010, Ict in het onderwijs: de stand van zaken, Zoetermeer.

Laan, G. van der, Plemper, E.M.T. \& Flikweert, M.W.M. (2003). Vraaggericht werken door Sociaal Pedagogische Diensten. Een vooronderzoek naar de professionele rol van maatschappelijk werkers. Utrecht: Verwey-Jonker Instituut.

Levy, F. (2010). How Technology Changes Demands for Human Skills. OECD Education Working Papers 45. Paris: OECD Publishing.

Ministerie van Volksgezondheid, Welzijn en Sport (2007), Niet van later zorg, Den Haag: VWS.

NUFFIC (2012), Mobiliteit in beeld 2012: Internationale mobiliteit in het Nederlandse hoger onderwijs, Den Haag: NUFFIC.

OECD (1999). Economic Outlook. Paris: OECD Publishing.

OECD (2010), The Nature of Learning: Using Research to Inspire Practice, Paris: OECD Publishing. 
Pavlin, S. and Svetlik, I. (2011). The World of Work and the Demand for Competences. In: J. Allen, S. Pavlin and R. Van der Velden (eds.) Competencies and Early Labour Market Careers of Higher education Graduates in Europe. University of Ljubljana: Faculty of Social Sciences, 73-106.

Rabobank (2011), Cijfers \& Trends, Branche-informatie: dienstverlening, $35^{\mathrm{c}}$ jaargang, maart 2011.

ROA (2009), De arbeidsmarkt naar opleiding en beroep tot 2014, Maastricht: Researchcentrum voor Onderwijs en Arbeidsmarkt.

ROA (2012a), Sectorrapportage Hoger Pedagogisch Onderwijs, HBO-raad, Den Haag.

ROA (2012b), Sectorrapportage Hoger Technisch Onderwijs, HBO-raad, Den Haag.

ROA (2012c), Sectorrapportage Hoger Gezondheidszorg Onderwijs en Hoger Sociaal-Agogisch Onderwijs, HBO-raad, Den Haag.

ROA (2012d), Sectorrapportage Hoger Economisch Onderwijs, HBO-raad, Den Haag.

ROA (2012e), Sectorrapportage Hoger Agrarisch Onderwijs, HBO-raad, Den Haag.

Scherpbier, A., et al (2010), Monitor beroepskeuzes, beroepsvorming en loopbanen in de geneeskunde, Een eerste schets, z.pl.

Vereniging van Nederlandse Vrouwelijke Artsen (2010), Feiten en ciffers over (aanstaande) artsen $m / v$, Nijmegen: UMC St. Radboud.

Vliet, K. van, et al (2004), Toekomstverkenning ten behoeve van een beroepenstructuur in zorg en welzijn, Verwey-Jonker Instituut 